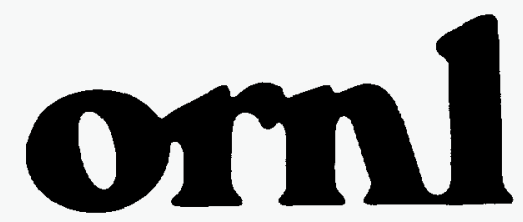

OAK RIDGE NATIONAL LABORATORY
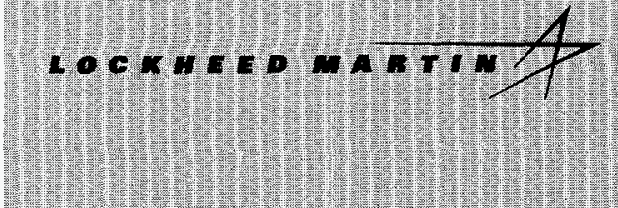

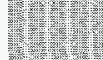

\section{列}

\section{(3)}

WWMGED AMD OPERATEO BY LOCKHEED MARTIV EUERGY RESEARCH CORPORAION FOATHE UTED STATES

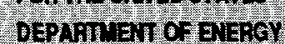

\section{RECEIVED \\ OCT 161996 \\ OSTI}

ORNLTM-13317

\title{
An Extension of the Validation of SCALE (SAS2H) Isotopic Predictions for PWR Spent Fuel
}

\author{
M. D. DeHart \\ O. W. Hermann
}


This report has been reproduced direclly from the best available copy.

Available to DOE and DOE contractors from the Office of Scientific and Technical Information, P.O.Box 62, Oak Ridge. TN 37831; prices available from (423) 576-8401, FTS 626-8401.

Available to the public from the National Technical Information Service, U.S. Department of Commerce, 5285 Port Royal Rd., Springfield, VA 22161

This report was prepared a an account of work sponsored by an agency of the United States Government. Neither the United States Government nor any agency thereof, nor any of their employees, makes any warranty, express or implied, or assumes any legal liability or responsibility for the accuracy, completeness, or usefulness of any information, apparatus, product, or process disclosed, or represents that its use would not infringe privately owned rights. Reference herein to any specific commercial product, process, or service by trade name, trademark, manufacturer, or otherwise, does not necessarily constitute or imply its endorsement, recommendation, or favoring by the United States Government or any agency thereof. The view and opinions of authors expressed herein do not necessarily state or reflect those of the UnitedStatesGovernment or any agency thereof. 


\section{DISCLAIMER}

Portions of this document may be illegible in electronic image products. Images are produced from the best available original document. 
Computational Physics and Engineering Division

AN EXTENSION OF THE VALIDATION OF SCALE (SAS2H) ISOTOPIC PREDICTIONS FOR PWR SPENT FUEL

M. D. DeHart and O. W. Hermann

Date Published: September 1996

Prepared for

Sandia National Laboratories

under subcontract $\mathrm{AD}-4072$ with Oak Ridge National Laboratory

Prepared by the

OAK RIDGE NATIONAL LABORATORY

managed by

LOCKHEED MARTIN ENERGY RESEARCH CORP.

for the

U.S. DEPARTMENT OF ENERGY

under contract DE-AC05-96OR22464 


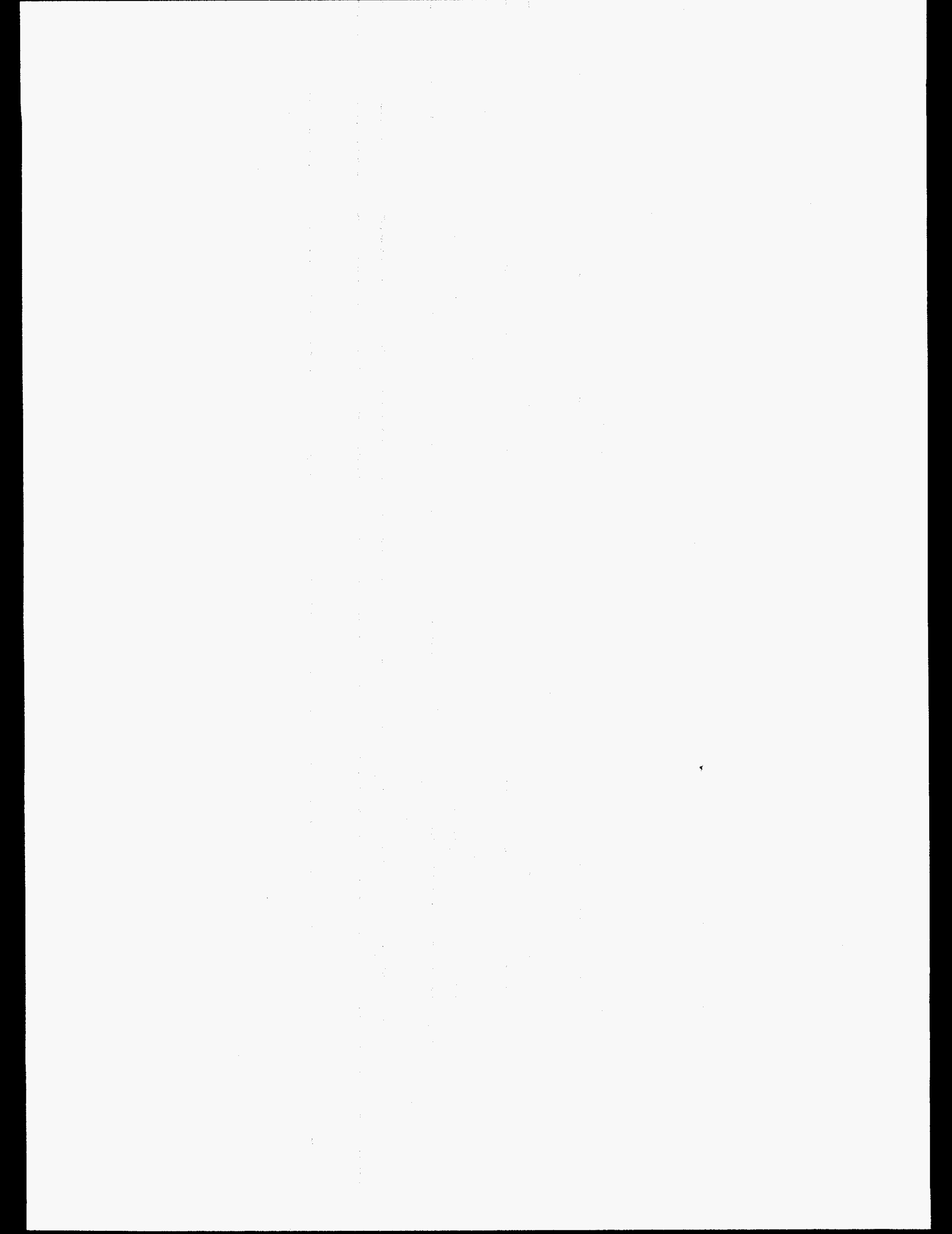




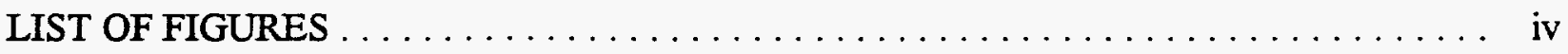

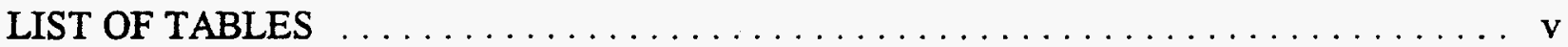

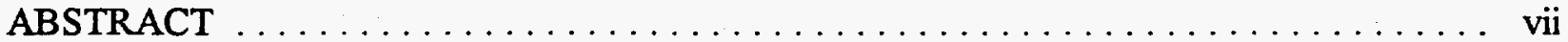

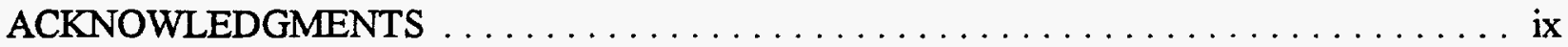

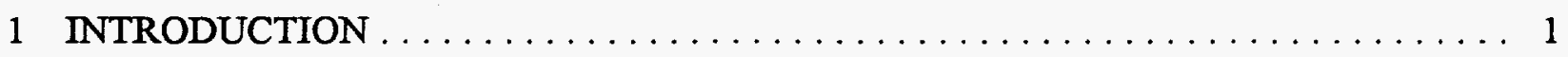

2 DEVELOPMENT OF FUEL ASSEMBLY MODELS FOR DEPLETION ANALYSES .. 4

2.1 TRINO VERCELLES PWR SPENT FUEL DEPLETION MODELS $\ldots \ldots \ldots \ldots 4$

2.2 TURKEY POINT UNIT 3 SPENT FUEL DEPLETION MODELS $\ldots \ldots \ldots \ldots . \ldots$

3 PREDICTED AND MEASURED ISOTOPIC COMPOSITIONS $\ldots \ldots \ldots \ldots \ldots \ldots$

3.1 TRINO VERCELLES PWR ISOTOPIC RESULTS $\ldots \ldots \ldots \ldots \ldots \ldots \ldots \ldots$

3.2 TURKEY POINT UNIT 3 PWR ISOTOPIC RESULTS $\ldots \ldots \ldots \ldots \ldots \ldots \ldots$

3.3 SUMMARY OF COMBINED ISOTOPIC RESULTS $\ldots \ldots \ldots \ldots \ldots \ldots \ldots$

4 STATISTICAL COMBINATION OF MEASURED-TO-COMPUTED

ISOTOPIC RATIOS . . . . . . . . . . . . . . . . . . . . . . . . 36

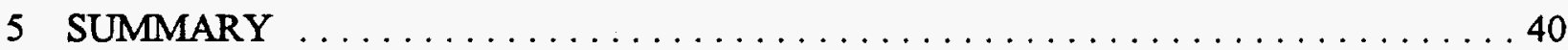

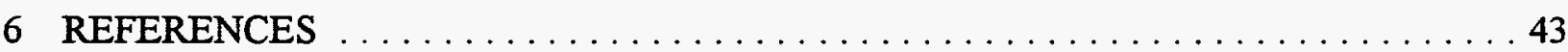

APPENDIX A. DESCRIPTION OF THE SCALE SAS2H DEPLETION APPROACH . . . 47

APPENDIX B. INPUT LISTINGS FOR TRINO VERCELLES SAS2H

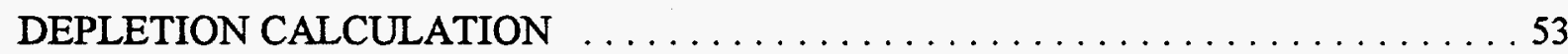

APPENDIX C. SAMPLE INPUT FOR A TURKEY POINT UNIT 3

SAS2H DEPLETION CALCULATION

APPENDIX D. MEASURED AND COMPUTED ISOTOPIC CONCENTRATIONS

FOR TRINO VERCELLES FUEL SAMPLES

APPENDIX E. MEASURED AND COMPUTED ISOTOPIC CONCENTRATIONS

FOR TURKEY POINT UNIT 3 FUEL SAMPLES $\ldots \ldots \ldots \ldots \ldots \ldots \ldots \ldots \ldots$

APPENDIX F. EFFECT OF INCORRECT ABSORBER SPECIFICATION FOR

TRINO VERCELLES CALCULATIONS 


\section{LIST OF FIGURES}

Figure

$\underline{\text { Page }}$

1 Core, assembly, and sample fuel pin configurations for Trino Vercelles $\ldots \ldots \ldots \ldots \ldots 6$

2 One-dimensional assembly approximation for Trino Vercelles assemblies $\ldots \ldots \ldots \ldots 12$

$315 \times 15$ assembly configuration for Turkey Point Unit 3 PWR . . . . . . . . . . . . 19

4 Percentage difference between measured and calculated results (27BURNUPLIB) . . . . 30

5 Percentage difference between measured and calculated results (44GROUPNDF5) $\ldots \ldots, 31$

6 Combined results for earlier and current validation analyses (27BURNUPLIB) $\ldots \ldots \ldots 34$

7 Combined results for earlier and current validation analyses (44GROUPNDF5) $\ldots \ldots \ldots 35$

A.1 Flow path invoked in SAS2H depletion and decay sequences $\ldots \ldots \ldots \ldots \ldots \ldots$. . . . 49 


\section{LIST OF TABLES}

$\underline{\text { Table }}$

Page

1 Basic parameters of the measured spent fuel $\ldots \ldots \ldots \ldots \ldots \ldots \ldots \ldots$

2 Design data for Trino Vercelles square fuel assemblies $\ldots \ldots \ldots \ldots \ldots \ldots \ldots \ldots$

3 Design data for Trino Vercelles cruciform fuel and control rod assemblies . . . . . . . . 9

4 Initial composition of Trino Vercelles fuel assemblies $\ldots \ldots \ldots \ldots \ldots \ldots \ldots$

5 Summary of general operations of cycles 1 and $2 \ldots \ldots \ldots \ldots \ldots \ldots$

6 Effective dimensions determined for 1-D SAS2H assembly model $\ldots \ldots \ldots \ldots \ldots$

7 Axially dependent effective fuel and water temperature and water densities $\ldots \ldots \ldots 13$

8 Fuel burnup and operating power histories for Trino Vercelles PWR pellet samples . . . . 15

9 Turkey Point Unit 3 PWR assembly and operating data $\ldots \ldots \ldots \ldots \ldots$

10 Initial composition of Turkey Point fuel assemblies $\ldots \ldots \ldots \ldots \ldots \ldots$

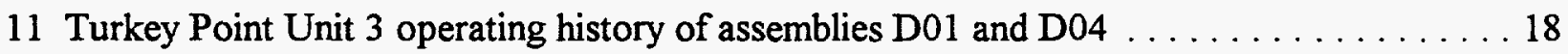

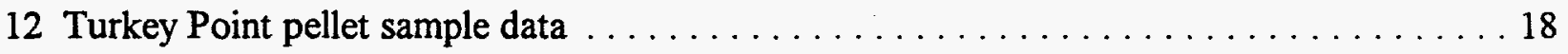

13 Average measured irradiation composition of Trino Vercelles PWR fuel $\ldots \ldots \ldots 21$

14 Percentage difference between measured and computed nuclide composition for Trino Vercelles PWR samples and averages (27BURNUPLIB library) . . . . . . . 24

15 Percentage difference between measured and computed nuclide composition6 for Trino Vercelles PWR samples and averages (44GROUPNDF5 library) . . . . . . 25

16 Measured irradiation composition of Turkey Point Unit 3 PWR fuel $\ldots \ldots \ldots$

17 Percentage difference between measured and computed nuclide compositions for Turkey Point Unit 3 PWR samples and averages (27BURNUPLIB library) . . . . . . 27

18 Percentage difference between measured and computed nuclide compositions for Turkey Point Unit 3 PWR samples and averages (44GROUPNDF5 library) . . . . . . 28 


\section{LIST OF TABLES (continued)}

Table

Page

19 Summary of percentage differences between measured and computed compositions in this study as averages and spreads

20 Combination of the current and previous validation summaries, listing percentage differences between measured and computed compositions

21 Best-estimate and conservative correction factors for $27 B$ URNUPLIB results $\ldots \ldots \ldots . . .38$

22 Best-estimate and conservative correction factors for 44GROUPNDF5 results . . . . . . . 39

A.1 List of fuel nuclides automatically included by SAS2 for neutronics processing $\ldots \ldots \ldots 50$

F.1 Results of corrected depletion calculations for Assembly 509-069, Rod E11, Level $2 \ldots 107$

F.2 Differences between reported and corrected calculated isotopic concentrations $\ldots \ldots \ldots 108$ 


\begin{abstract}
Isotopic characterization of spent fuel via depletion and decay calculations is necessary for determination of source terms for subsequent system analyses involving heat transfer, radiation shielding, isotopic migration, etc. Unlike fresh fuel assumptions typically employed in the criticality safety analysis of spent fuel configurations, burnup credit applications also rely on depletion and decay calculations to predict the isotopic composition of spent fuel. These isotopics are used in subsequent criticality calculations to assess the reduced worth of spent fuel. To validate the codes and data used in depletion approaches, experimental measurements are compared with numerical predictions for relevant spent fuel samples. Such comparisons have been performed in earlier work at the Oak Ridge National Laboratory (ORNL). This report describes additional independent measurements and corresponding calculations, which supplement the results of the earlier work. The current work includes measured isotopic data from 19 spent fuel samples obtained from the Italian Trino Vercelles pressurized-water reactor (PWR) and the U.S. Turkey Point Unit 3 PWR.

In addition, an approach to determine biases and uncertainties between calculated and measured isotopic concentrations is discussed, together with a method to statistically combine these terms to obtain a conservative estimate of spent fuel isotopic concentrations. Results are presented based on the combination of measured-to-calculated ratios for earlier work and the current analyses.

The results described herein represent an extension to a new reactor design not included in the earlier work, and spent fuel samples with enrichment as high as 3.9 wt $\%{ }^{235} \mathrm{U}$. Results for the current work are found to be, for the most part, consistent with the findings of the earlier work. This consistency was observed for results obtained from each of two different crosssection libraries and suggests that the estimated biases determined for each of the isotopes in the earlier work are reasonably good estimates, as the additional measurement/calculated ratios resulting from the current work tend to confirm these estimates.
\end{abstract}




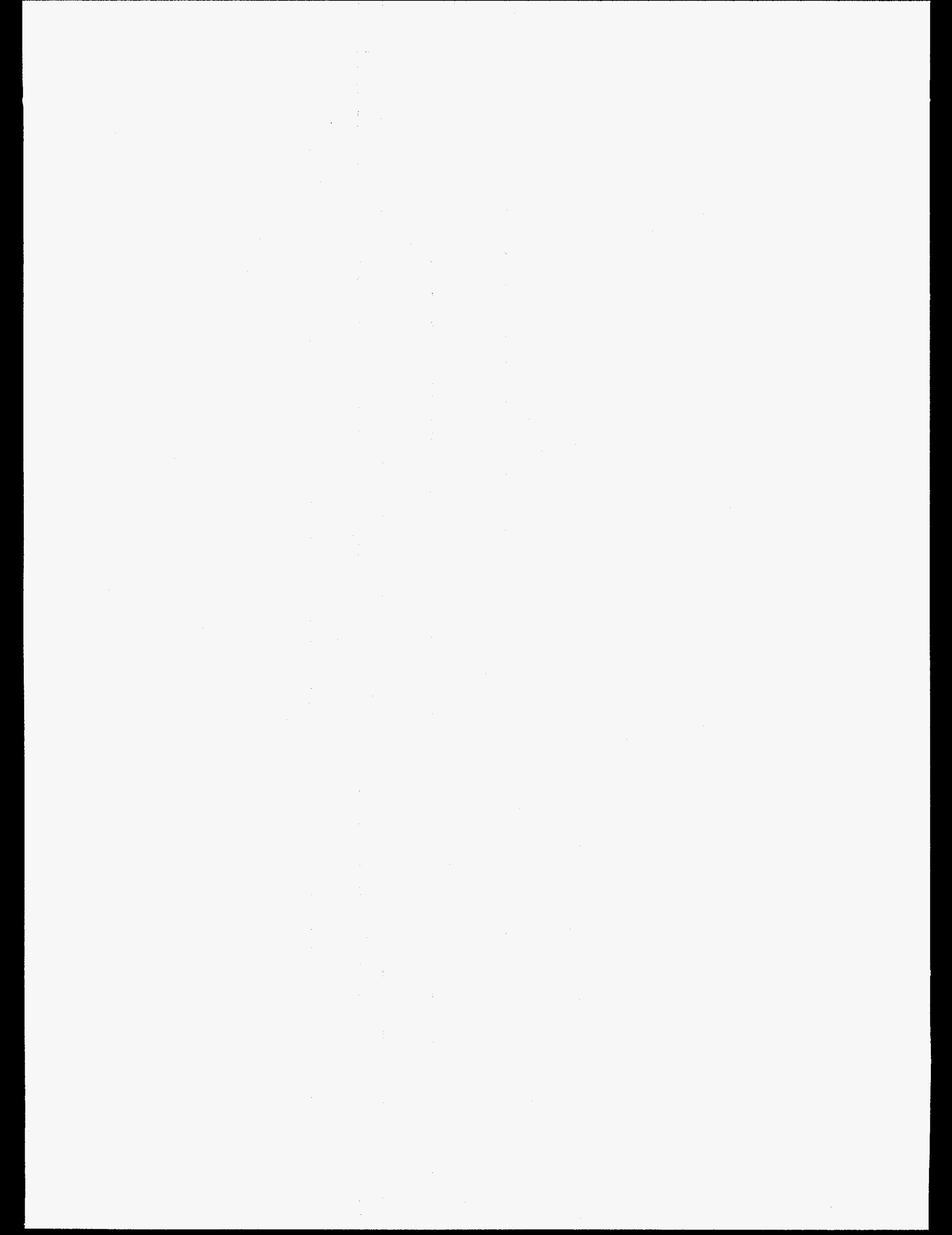




\section{ACKNOWLEDGMENTS}

The authors wish to express their appreciation to several individuals who contributed their ideas and efforts in the analyses described herein. Particular thanks go to F. J. Davis of Sandia National Laboratories, who provided technical oversight for most of the duration of the work, C. V. Parks of Oak Ridge National Laboratory, who provided both programmatic and technical guidance in the preparation of this report and also reviewed and commented on the original draft; also, technical review and comments were provided by B. D. Murphy of Oak Ridge National Laboratory, Meraj Rahimi of E. R. Johnson and Associates, and K. D. Seager and M. C. Brady of Sandia National Laboratories. Final clearance and release of the report were facilitated by D. E. Hampton of Sandia National Laboratories. Last, but not least, the authors also wish to acknowledge L. F. Norris for her continuing efforts in the text editing, formatting, and release of this report.

This work was sponsored as part of the Cask System Development Program within the U.S. Department of Energy's Office of Civilian Radioactive Waste Management. This report and all calculational work described herein were performed by the Oak Ridge National Laboratory for Sandia National Laboratories in accordance with the technical and quality assurance requirements specified in Sandia National Laboratories subcontract AD-4072 and the Sandia Burnup Credit Quality Assurance Program and implementing procedures. 


\section{INTRODUCTION}

The isotopic composition of spent fuel discharged from a commercial light-water-reactor (LWR) is a key factor in the design, licensing, and operation of radioactive waste transportation systems, interim storage facilities, and a final repository site. An accurate estimate of the timedependent radionuclide inventory in spent fuel is necessary to evaluate many spent fuel issues, including (1) neutron multiplication for criticality safety concerns, (2) neutron and gamma-ray source terms for shielding analyses, (3) decay-heat source terms for temperature distribution and heat-transfer concerns, and (4) radiological and chemical toxicity terms for environmental impact considerations. One of the functions of the SCALE (Standardized Computer Analyses for Licensing Evaluation) code system ${ }^{1}$ is the capability to predict the isotopic composition of discharged LWR fuel. Recent applications of nuclide depletion and production estimates for LWR fuel include criticality analyses for the evaluation of spent fuel shipment or storage packages. ${ }^{2-6}$ The ANSI/ANS 8.1 criticality safety standard ${ }^{7}$ recommends the validation of the analytical methods used in these spent fuel criticality analyses. This report describes efforts to validate the capability of Version 4.2 of the SCALE system to predict isotopic concentrations as part of a larger effort to validate SCALE for the criticality analysis of spent fuel configurations. Nevertheless, the results presented here should be applicable to other aspects of spent fuel analysis, as mentioned above.

A study of the use of SCALE-4 depletion analysis methods for pressurized-water-reactor (PWR) spent fuel was recently conducted ${ }^{8,9}$ by Oak Ridge National Laboratory (ORNL). The earlier work was based on a comparison of predicted (calculated) with measured isotopic concentrations for 19 spent fuel samples from 10 fuel assemblies representing three different PWRs. The current report will present results of further SCALE-4.2 depletion analyses ${ }^{10,11}$ for 19 additional PWR spent fuel samples, obtained from 5 fuel assemblies of 2 additional PWRs not included in the earlier study. The report will focus on the development of assembly-specific depletion models for each of the unique assemblies studied in these analyses and a comparison of isotopic concentrations predicted using these models to measured concentrations for each fuel sample. This report will also include a statistical combination ${ }^{3}$ of the current results with those reported in refs. 8 and 9 to obtain an improved estimate of error associated with isotopic predictions. 
The 19 fuel samples analyzed in this work were modeled based on the operational data available for samples obtained from the Trino Vercelles PWR (Italy) and the Turkey Point Unit 3 PWR (U.S.). Trino Vercelles was selected because of the relatively high (3.9 wt \%) enrichment of one fuel sample and because of its significantly different core design; Turkey Point was selected simply because of detailed data that were readily available. Comparisons were made for selected isotopes measured via radiochemical analysis of each fuel sample. The isotopic measurements for Trino Vercelles spent fuel were conducted by the Ispra (Italy) and Karlsruhe (Germany) facilities of the European Joint Research Centre and provided data for 14 fuel samples. ${ }^{12-14}$ Burnup analyses for the five Turkey Point Unit 3 spent fuel samples were performed by Battelle Columbus Laboratory (BCL) with direction provided by the Hanford Engineering Development Laboratory (HEDL). ${ }^{15,16}$ Data collected under these programs did not fall under the quality assurance standards in place for this document, and are therefore not considered explicitly qualified. However, these data are felt to be implicitly qualified because (1) the nature of procedures for handling, processing, and storage of nuclear materials is inherently consistent with quality assurance principles, and (2) the data reported have received several levels of technical review in multiple publications. ${ }^{12-16}$

The parameters of the problems analyzed in this study cover a fairly wide range. The fuel burnups are in the range of 11.53 to 31.56 gigawatt days/metric ton $U$ (GWd/MTU). The initial fuel enrichments vary from 2.56 to $3.90 \mathrm{wt} \%{ }^{235} \mathrm{U}$. The two PWR designs are significantly different; as a result there are significant variations in assembly-specific powers (7.15 to $33.12 \mathrm{MW}$ MTU), effective fuel temperatures ( 915 to $1015 \mathrm{~K}$ ), moderator densities $\left(0.73\right.$ to $\left.0.80 \mathrm{~g} / \mathrm{cm}^{3}\right)$, and other pertinent operating conditions.

For consistency with earlier work, ${ }^{8,9}$ the results reported here were produced using the SAS2 $\mathrm{H}^{10}$ control module in Version 4.2 of the SCALE code system. SAS2H is a multicode sequence that determines the isotopic composition of spent fuel using the ORIGEN-S code ${ }^{11}$ for depletion and decay calculations and a one-dimensional (1-D) neutronics model of a LWR fuel assembly to prepare burnup-dependent cross sections for ORIGEN-S. The details of SAS2H depletion calculations are provided in Appendix A. All calculations were performed on an IBM RS/6000-580 workstation under AIX Version 3 Release 2.

The nature of the neutron cross-section data used in fuel depletion analyses by the SCALE system is a significant aspect of a validation effort. Two different cross-section libraries were 
applied in these analyses: the hybrid SCALE 27-group burnup library² and the more recent 44-group library. The 27-group cross-section library has actinide and light-element data derived from Version IV of the Evaluated Nuclear Data Files (ENDF) and fission-product data processed from ENDF/B-V files. ${ }^{17}$ The 44-group library ${ }^{18}$ applied in these analyses was derived from ENDF/B-V data, with the exception of three nuclides. The cross sections for ${ }^{16} \mathrm{O},{ }^{154} \mathrm{Eu}$, and ${ }^{155} \mathrm{Eu}$ in this library were obtained from ENDF/B-VI files. The ENDF/B-VI files provided data with a significant change to resonance region cross sections for ${ }^{154} \mathrm{Eu}$ and ${ }^{155} \mathrm{Eu}$ (ref. 19) which result in improved predictions for ${ }^{155} \mathrm{Eu}$ and ${ }^{155} \mathrm{Gd}$ (ref. 9). The ${ }^{16} \mathrm{O}$ change involved improvements in the scattering kernel and is insignificant in the analyses described in this report.

The reactor configurations and SAS2H models used to represent each fuel sample are described in the following section. In the subsequent sections, comparisons of the predicted and measured nuclide compositions are presented and are combined statistically with the results of the earlier analyses ${ }^{8,9}$ to obtain best-estimate and conservatively bounding estimates of nuclide concentrations in spent fuel based on SAS2H isotopic predictions. 


\section{DEVELOPMENT OF FUEL ASSEMBLY MODELS FOR DEPLETION ANALYSES}

The 19 spent fuel cases selected as a basis for SCALE-4 depletion analysis in this validation study were obtained from radiochemical assay data for spent fuel samples from the Trino Vercelles and Turkey Point Unit 3 PWRs. The initial ${ }^{235} \mathrm{U}$ enrichment, accumulated burnup, axial location, and cooling time are basic parameters in characterizing the analyzed samples of spent fuel. Table 1 shows these parameters for 14 samples obtained from 3 Trino Vercelles assemblies and 5 samples from 2 Turkey Point assemblies. The parameters in this table, in conjunction with the similar data described in ref. 9, are representative of a large percentage of the current PWR spent fuel inventory. The following subsections provide, for each reactor type, the fuel assembly design data, pertinent control rod data, and operating conditions assembled from various sources ${ }^{12-16,20-22}$ in order to perform the depletion calculations for this study.

\subsection{TRINO VERCELLES PWR SPENT FUEL DEPLETION MODELS}

The Trino Vercelles Nuclear Power Plant is a 825-MW PWR located in Italy and operated by the Ente Nazionale per l'Energià Elettricà (ENEL). The steam generation plant and fuel were designed by Westinghouse Electric Corp. The reactor is based on one of the earlier Westinghouse designs and is unlike most PWR designs in the United States. However, its design is similar to that of the U.S. Yankee Rowe PWR. Use of this uncommon design in this validation will serve to demonstrate the relative insensitivity of isotopic depletion methods to PWR reactor core design.

Radiochemical assay data obtained from the analysis of three fuel assemblies were used in this study. Two of the assemblies, numbered 509-104 and 509-032, were irradiated in the core during the first cycle only. The remaining assembly, identified as 509-069, was irradiated during both the first and second fuel cycles.

The Trino reactor core contains assemblies with two different configurations, square and cruciform. All square assemblies contain fuel and are based on a $15 \times 15$ lattice of fuel pins with 16 of the outer pins excluded to accommodate cruciform positions, as illustrated in Fig. 1. This figure shows the details of the assembly and core layouts for the Trino core. As indicated in the figure, square assemblies are surrounded by a stainless steel channel tube. The center position in 
Table 1. Basic parameters of the measured spent fuel

\begin{tabular}{|c|c|c|c|c|c|c|c|}
\hline No. & Unit name & $\begin{array}{c}\text { Test } \\
\text { assembly } \\
\text { (pin No.) }\end{array}$ & $\begin{array}{c}\text { Initial } \\
\text { enrichment } \\
\left.\text { (wt \% }{ }^{235} \mathrm{U}\right)\end{array}$ & $\begin{array}{c}\text { Axial } \\
\text { level } \\
\text { No. }\end{array}$ & $\begin{array}{c}\text { Axial } \\
\text { location }^{a} \\
(\mathrm{~cm})\end{array}$ & $\begin{array}{c}\text { Burnup } \\
\text { (GWd/MTU) }\end{array}$ & $\begin{array}{l}\text { Cooling } \\
\text { time (d) }\end{array}$ \\
\hline 1 & Trino Vercelles & 509-104(M11) & 3.897 & 7 & 79.2 & 12.042 & $10^{b}$ \\
\hline $\begin{array}{l}2 \\
3 \\
4\end{array}$ & Trino Vercelles & $509-032(\mathrm{E} 11)$ & 3.13 & $\begin{array}{l}4 \\
7 \\
9\end{array}$ & $\begin{array}{l}158.5 \\
79.2 \\
26.4\end{array}$ & $\begin{array}{l}15.377 \\
15.898 \\
11.529\end{array}$ & $10^{6}$ \\
\hline $\begin{array}{l}5 \\
6 \\
7 \\
8 \\
9 \\
10 \\
11 \\
12 \\
13 \\
14\end{array}$ & Trino Vercelles & $\begin{array}{l}509-069(\mathrm{E} 11) \\
509-069(\mathrm{E} 5) \\
509-069(\mathrm{~L} 11)\end{array}$ & 3.13 & $\begin{array}{l}1 \\
2 \\
4 \\
7 \\
4 \\
7 \\
4 \\
7 \\
4 \\
7\end{array}$ & $\begin{array}{l}237.7 \\
211.3 \\
158.5 \\
79.2 \\
158.5 \\
79.2 \\
158.5 \\
79.2 \\
158.5 \\
79.2\end{array}$ & $\begin{array}{l}12.859 \\
20.602 \\
23.718 \\
24.304 \\
23.867 \\
24.548 \\
23.928 \\
24.362 \\
24.330 \\
24.313\end{array}$ & $10^{b}$ \\
\hline $\begin{array}{l}15 \\
16 \\
17\end{array}$ & Turkey Point Unit 3 & $\begin{array}{l}\text { D01 (G9) } \\
\text { D01 (G10) } \\
\text { D01 (H9) }\end{array}$ & 2.556 & $\begin{array}{l}\text { NA } \\
\text { NA } \\
\text { NA }\end{array}$ & $\begin{array}{l}167.6 \\
167.0 \\
167.0\end{array}$ & $\begin{array}{l}30.720 \\
30.510 \\
31.560\end{array}$ & 927 \\
\hline $\begin{array}{l}18 \\
19\end{array}$ & Turkey Point Unit 3 & $\begin{array}{l}\text { D04 (G9) } \\
\text { D04 (G10) }\end{array}$ & 2.556 & $\begin{array}{l}\text { NA } \\
\text { NA }\end{array}$ & $\begin{array}{l}167.6 \\
167.0\end{array}$ & $\begin{array}{l}31.260 \\
31.310\end{array}$ & 927 \\
\hline
\end{tabular}

${ }^{a}$ Height of sample above bottom of fuel.

${ }^{b}$ Isotopic values were adjusted to discharge time. 
Core Layout for Cycles 1 and 2
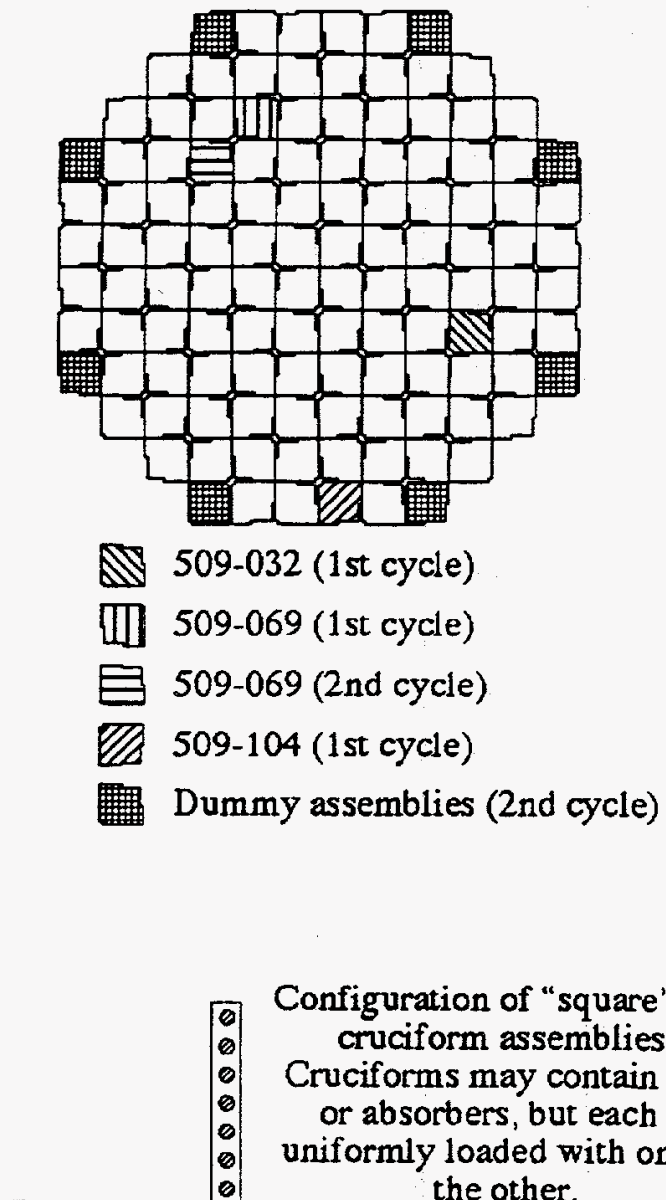

Configuration of "square" and cruciform assemblies.

Cruciforms may contain fuel or absorbers, but each is uniformly loaded with one or the other.

000000000

1000000000000000

00000000000

- 00000000000000

- 00000000000000

- 00000000000000

- 00000000000000

- 00000000000000

- $0000000000000 \overline{0}$

0000000000000000

0000000000000000

000000000000000

0000000000000000

10000000000000000

000000000000000

00000000000000000000000

- Square Assembly Element (fuel rod)

- Cruciform Assembly Element (fuel or control rod)

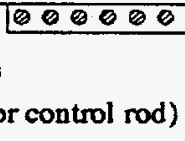

0
0
0
0
0
0
0
Locations of Fuel Rods Containing Samples

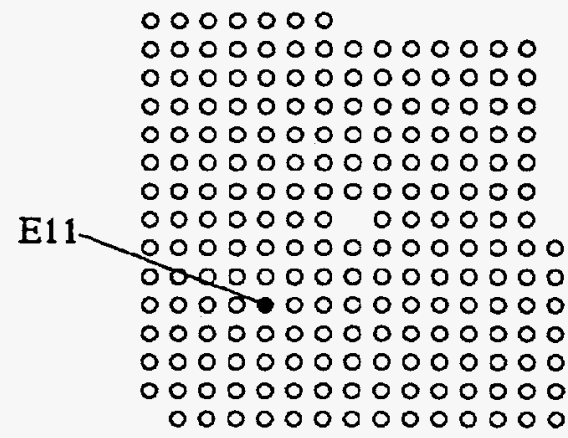

509-032

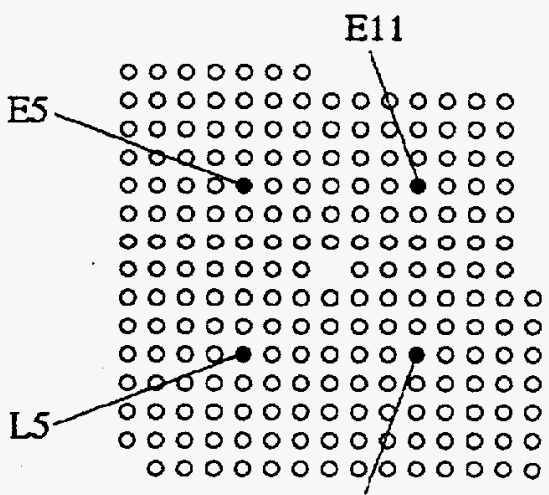

L11

509-069
M11 00000000000000 000000000000000 000000000000000 000000000000000 000000000000000 000000000000000 000000000000000 0000000000000 00000000000000 00000000000000 00000000000000 00000000000000 00000000000000 00000000000000 0000000

509-104

Fig. 1. Core, assembly, and sample fuel pin configurations for Trino Vercelles. 
each assembly is used for instrumentation and was assumed vacant for depletion calculations. Cruciform assemblies can contain either fuel rods or $\mathrm{Ag}-\mathrm{In}-\mathrm{Cd}$ absorber rods. Cruciforms containing absorber rods are partially inserted from the top during operation; the remaining volume below the absorber cruciform contains coolant. Design data for square fuel assemblies ${ }^{12}$ and cruciform fuel and absorber rods ${ }^{12-14}$ are given in Tables 2 and 3, respectively.

Spent fuel samples from the Trino Vercelles PWR were obtained from three square fuel assemblies. Initial enrichments varied between the three assemblies; initial isotopic compositions based on these specifications are given in Table 4. Initial ${ }^{235} \mathrm{U}$ enrichment was given in ref. 12; initial ${ }^{234} \mathrm{U},{ }^{236} \mathrm{U},{ }^{238} \mathrm{U}$ concentrations were estimated using empirical relationships. ${ }^{21}$

During cycle 1 , two downtime intervals occurred prior to the end of the cycle. For this reason, cycle 1 was represented as three distinct subcycle periods. Cycle 2 was completed with no downtime, hence it was represented as a single operating period.

Operational parameters for cycles 1 and 2 and for subcycle periods I, II, and III of cycle 1 are given in Table 5. Burnups given in the table for each period or cycle were used to determine the relative specific power for each assembly during depletion steps. The exact specific power used for each individual sample in a given assembly was determined from the final burnup of the sample (given in Table 1). Note that assembly-specific burnups were supplied for assembly 509-069 only. These data were not given for the other two assemblies; relative burnup per depletion step for these assemblies was assumed based on total core burnup data.

As was indicated in Table 1, isotopic measurements were based on a 10-day cooling time. However, this 10-day cooling time was an assumption made in this work. Measurements were actually performed several years after shutdown, but isotopic concentrations reported in ref. 12 were adjusted back to "time zero." It was not clear whether the adjusted time represented actual shutdown time or discharge time, which is usually several days after shutdown. Typically, such adjustments are made to put a number of measurements on a common basis; these adjustments are calculated, and are generally performed to estimate isotopic composition at discharge time. Assuming this was the intent of original experimentalists, a 10-day cooling time was taken to represent the time between shutdown and discharge. Thus SAS2H calculations reported here include a 10-day postirradiation decay period. Note that a longer post-irradiation discharge time (20 to 50 days) would not significantly affect isotopic compositions. However, a shorter decay period would affect 
Table 2. Design data for Trino Vercelles square fuel assemblies

\begin{tabular}{|c|c|}
\hline Parameter & Data \\
\hline $\begin{array}{l}\text { Square fuel assembly data } \\
\text { Designer } \\
\text { Lattice } \\
\text { Square assemblies/core, cycle } 1 \text { (cycle 2) } \\
\text { Number of fuel rods } \\
\text { Number of inner holes } \\
\text { Assembly fuel, } \mathrm{kg} \mathrm{UO} \\
\text { Water pressure, } \mathrm{kg} / \mathrm{cm}^{2} \\
\text { Average coolant temperature, }{ }^{\circ} \mathrm{C}, \text { cycle } 1 \text { (cycle 2) } \\
\text { Inlet/outlet temperature increase, }{ }^{\circ} \mathrm{C} \\
\text { Assembly tube outer side, cm } \\
\text { Channel tube thickness, cm } \\
\text { Channel tube material }\end{array}$ & $\begin{array}{l}\text { Westinghouse } \\
15 \times 15^{a} \\
120(112) \\
208 \\
1 \\
353.81 \\
140 \\
279(269) \\
30.0 \\
20.1 \\
0.06 \\
\text { SS-304 }\end{array}$ \\
\hline $\begin{array}{l}\text { Fuel rod data } \\
\text { Type fuel pellet } \\
\text { Stack density with no gap, } \mathrm{g} / \mathrm{cm}^{3} \\
\text { Rod pitch, cm (in.) } \\
\text { Rod OD, cm (in.) } \\
\text { Rod ID, cm (in.) } \\
\text { Active fuel length, cm (in.) } \\
\text { Clad material } \\
\text { Clad temperature, K }\end{array}$ & $\begin{array}{l}\mathrm{UO}_{2} \\
10.079^{b} \\
1.303(0.513) \\
0.9786(0.3853) \\
0.9020(0.3551) \\
264.1(104.0) \\
\mathrm{SS}-304 \\
570^{c}\end{array}$ \\
\hline
\end{tabular}

The lattice is a $15 \times 15$ array with 16 pins excluded in the outer rows or columns to accommodate space for cruciform assemblies (Table 3).

${ }^{b}$ Computed from the fuel mass and volume listed in this table.

${ }^{c}$ Clad temperature was not available in literature. Temperature data for a similar design (Yankee Rowe PWR ${ }^{20}$ ) was used. 
Table 3. Design data for Trino Vercelles cruciform fuel and control rod assemblies

\begin{tabular}{l|l}
\hline \multicolumn{1}{c|}{ Parameter } & \multicolumn{1}{c}{ Data } \\
\hline Number of cruciform assemblies/core & 52 \\
& \\
Cruciform fuel assembly data & 24 \\
Number of assemblies/core & 44 \\
Fuel weight/assembly, kg UO ${ }_{2}$ & \\
& 28 \\
Cruciform control rod data & \\
Number of control assemblies/core & 85 \\
Neutron absorber composition, wt \% & 15 \\
Ag & 5 \\
In & $10.159(0.341)^{a}$ \\
Cd & 32 \\
Absorber density, g/cm ${ }^{3}$ (lbs/in. ${ }^{3}$ ) & $1.001(0.394)$ \\
Number of absorber rods/control rod & 0.0432 \\
Absorber rod OD, cm (in.) & 30 \\
Absorber rod clad thickness, cm & \\
Maximum control group insertion (Period I), \% & \\
\hline
\end{tabular}

${ }^{a}$ Absorber density was not given. Applied the density data for the same Ag-In-Cd ratios that are listed in FSAR for Sequoyah Nuclear Plant Units 1 and 2.

Table 4. Initial composition of Trino Vercelles fuel assemblies

\begin{tabular}{l|c|c|c}
\hline \multirow{2}{*}{$\begin{array}{l}\text { Uranium } \\
\text { isotope }\end{array}$} & \multicolumn{3}{|c}{ Assembly ID } \\
\cline { 2 - 4 } & $509-104$ & $509-32$ & $509-069$ \\
\hline wt \% ${ }^{235} \mathrm{U}$ & 3.897 & 3.13 & 3.13 \\
wt \% ${ }^{234} \mathrm{U}$ & 0.035 & 0.028 & 0.028 \\
wt \% ${ }^{236} \mathrm{U}$ & 0.018 & 0.014 & 0.014 \\
wt \% ${ }^{238} \mathrm{U}$ & 96.050 & 96.828 & 96.828 \\
\hline
\end{tabular}


Table 5. Summary of general operations of cycles 1 and 2

\begin{tabular}{l|l|l|l|l}
\hline \multicolumn{1}{c|}{ Parameter } & \multicolumn{4}{c}{ Cycle/period data } \\
\hline Cycle & 1 & 1 & 1 & 2 \\
Period & I & II & III & All of cycle \\
Starting date & $10 / 23 / 64$ & $8 / 31 / 65$ & $7 / 11 / 66$ & $5 / 20 / 70$ \\
Uptime, d & 226 & 263 & 292 & 416 \\
Downtime, d & 86 & 51 & 1117 & 0 \\
Coolant average temperature, ${ }^{\circ} \mathrm{C}$ & 282 & 278 & 278 & 269 \\
Control rod insertion, \% & 30 & $4^{d}$ & $4^{d}$ & $0^{a}$ \\
Average boron, ppm (wt) & 1175 & 850 & 325 & $650^{b}$ \\
509-069 burnup, GWd/MTU & 2.726 & 4.927 & 6.327 & 7.720 \\
Core burnup, ${ }^{6}$ GWd/MTU & 2.260 & 4.085 & 5.245 & NA \\
\hline
\end{tabular}

Not given, assumed to be insignificant.

Not given, assumed average of cycle 1 range: 1,300 to $0 \mathrm{ppm}$.

Applied to the cycle 1 burnup for assemblies 509-032 and 509-104.

${ }^{\alpha}$ Not modeled, assumed to be negligible.

isotopes whose inventory comes in part from the decay of short-lived parents. The nuclide most significantly affected by this decay period is ${ }^{239} \mathrm{Pu}$, which increases in inventory by roughly $1 \%$ during the first ten days post-irradiation due to the beta decay of ${ }^{239} \mathrm{U}$ and ${ }^{239} \mathrm{~Np}$ (e.g., ${ }^{239} \mathrm{U}\left(\mathrm{T}_{1 / 2}=23.5\right.$ $\left.\mathrm{m}) \rightarrow{ }^{239} \mathrm{~Np}\left(\mathrm{~T}_{1 / 2}=2.350 \mathrm{~d}\right) \rightarrow{ }^{239} \mathrm{Pu}\right]$.

The SAS2H Pass A pin-cell calculation was based on the nominal fuel pin dimensions and pitch as specified in Table 2. However, the Trino Vercelles assembly lattice is more complex than those of PWR configurations analyzed in earlier work; channel tubes and external cruciform assemblies are not present in conventional PWR designs. Although cruciforms loaded with fuel result in a near-uniform assembly lattice, cruciforms loaded with $\mathrm{Ag}$-In-Cd absorber rods result in an asymmetric assembly configuration. In addition, axial symmetry is defeated by the partial insertion of control rods during operation. This problem is aggravated by the fact that control assemblies may be moved vertically during irradiation. Hence, one must make assumptions and approximations in the development of a 1-D SAS2H Pass B model to approximate the assembly layout.

Because of the 1-D nature of SAS2H models, assembly lattices are generally approximated by a 1-D radial model. Thus it is necessary to determine effective radii that can account for the presence of significant material in a manner that conserves masses. Figure 1 illustrates the locations 
of each of the rods from which spent fuel samples were obtained within each assembly: E11 in assembly 509-032, E5, E11, L5, and L11 in 509-069, and M11 in 509-104. Each of these fuel rods is located roughly halfway between the center and the edge of the assembly, and thus will be well approximated by the average behavior of a circular ring of fuel/moderator mixture surrounding the vacant position at the center of the assembly. The form of the 1-D representation is shown in Fig. 2 , centered around the vacant center of the assembly. This figure is drawn to scale, and shows the relative size of each different zone in the 1-D approximation. Table 6 lists the contents and effective radii of each zone.

A complication encountered in this procedure was introduced by the fact that although detailed information was provided for most core parameters, these data did not include the exact location of control rod and fuel rod cruciforms in the core. All that is known is the total number of each type of cruciform. Some assemblies might effectively contain 224 fuel pins (208 square assembly pins +16 cruciform fuel pins), while others could contain as few as 208 fuel pins and 16 control rod pins. Thus it was decided to base each assembly model on the average number of cruciform fuel rods and cruciform absorber rods per assembly in the core. With 32 fuel pins/cruciform assembly and 24 cruciform assemblies mixed with 120 square assemblies, there are 6.4 cruciform pins per square assembly. Since SAS2H requires an integral number of fuel pins per assembly, the average assembly was assumed to contain $214(208+6)$ fuel pins.

The effective area of absorber material per assembly was calculated knowing the size and number of absorber rods present and dividing by the number of assemblies in the core. However, since the control rods were only inserted by $30 \%$ during Period I of Cycle 1 , the effective area of the control rods was reduced to $30 \%$ of the total area. Because of the 1-D nature of SAS2H, absorber material placed in the model simulates a fully inserted rod (since axial uniformity is implicit in a 1-D radial model); however, weighting the area of the control rod area by the fraction of insertion helps to compensate for this approximation. For Periods II and III of Cycle 1, control rods were inserted $4 \%$ of full length, and were completely withdrawn during Cycle 2 . It was assumed that the $4 \%$ insertion was negligible during Periods II and III. Thus it was assumed that no absorber material was present during these exposure periods, and the effective area of absorber was replaced with moderator for these periods. 


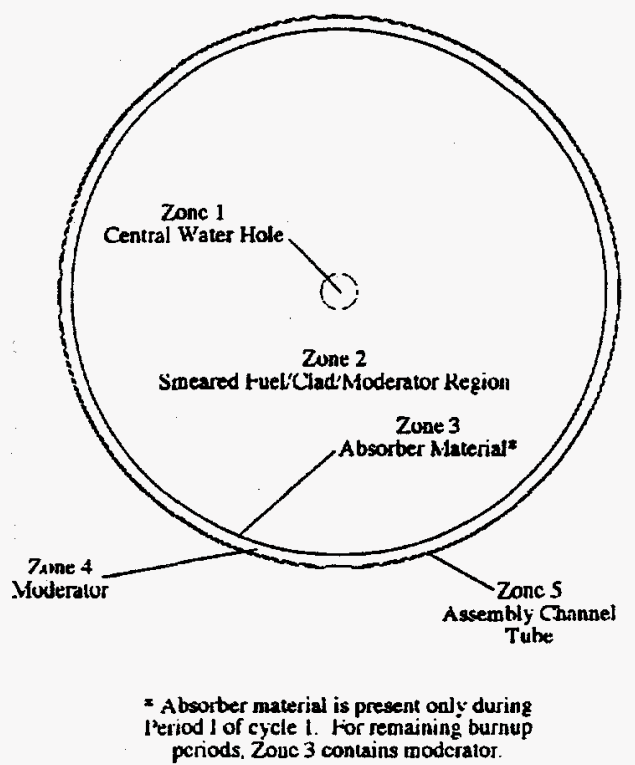

Fig. 2. One-dimensional assembly approximation for Trino Vercelles assemblies.

Table 6. Effective dimensions determined for 1-D SAS2H assembly model

\begin{tabular}{llccc}
\hline $\begin{array}{l}\text { Radial } \\
\text { zone }\end{array}$ & Composition & Area $\left(\mathrm{cm}^{2}\right)$ & $\begin{array}{c}\text { Cumulative } \\
\text { area }\left(\mathrm{cm}^{2}\right)\end{array}$ & $\begin{array}{c}\text { Effective } \\
\text { radius }(\mathrm{cm})\end{array}$ \\
\hline 1 & Borated moderator & 1.698 & 1.698 & 0.735 \\
2 & $\begin{array}{l}\text { Homogenized fuel, } \\
\text { clad, and borated } \\
\text { moderator }\end{array}$ & 363.332 & 365.030 & 10.779 \\
3 & $\begin{array}{l}\text { Period I, Cycle 1: } \\
\text { homogenized Ag- } \\
\text { In-Cd absorber and } \\
\text { clad }\end{array}$ & 2.034 & 367.064 & 10.809 \\
& $\begin{array}{l}\text { Remaining Periods } \\
\text { and Cycles: borated } \\
\text { moderator }\end{array}$ & & & \\
4 & Borated moderator & 32.136 & 399.200 & 11.273 \\
5 & Stainless steel & 4.810 & 404.010 & 11.340 \\
\hline
\end{tabular}


Zone 4 of the radial model accounts for all moderator around and below each control rod. The final radius represents the total thickness of stainless steel in the assembly and cruciform assembly channel tubes. Calculations were performed using a reflective boundary condition beyond the outermost zone.

As was shown in Table 1, spent fuel samples were obtained from a variety of axial locations within the cores. The 14 different Trino Vercelles fuel samples included in this study were taken from the fuel pins identified in Table 1 and located as shown in Fig. 1. From each fuel rod, up to four samples were studied, each at different axial heights. In characterizing the rod axially in the original radiochemical assay work, the length of the rod was subdivided into ten equal-height levels where levels 1 and 10 are located at the top and the bottom of the rod, respectively. The sample pellet locations were identified by level number and were taken from the midpoint of the corresponding level number. The exact axial location of a pellet is not important neutronically since axial uniformity is assumed in depletion calculations; however, efforts were taken to match pellet locations to the expected local temperatures and moderator density corresponding to that height. Axially dependent material temperatures and moderator densities are given in Table 7 for each axial location. Water temperatures were computed using data given in Tables 2 and 5 along with the axially varying temperature formulation used in the previous validation study. ${ }^{9}$ The water densities were derived from correlations ${ }^{1}$ based on cycle operating pressure data and the calculated water temperature. The effective fuel temperatures were computed from resonance-effective temperatures given in operating data for the similar-design Yankee Rowe PWR. ${ }^{20}$

Table 7. Axially dependent effective fuel and water temperature and water densities

\begin{tabular}{l|c|c|c|c|c|c}
\hline \multirow{2}{*}{$\begin{array}{l}\text { Level } \\
\text { No. }\end{array}$} & \multicolumn{2}{|c|}{$\begin{array}{c}\text { Effective fuel } \\
\text { temperature, K }\end{array}$} & \multicolumn{2}{c|}{$\begin{array}{c}\text { Effective water } \\
\text { temperature, K }\end{array}$} & \multicolumn{2}{c}{$\begin{array}{c}\text { Water density, } \\
\mathrm{g} / \mathrm{cm}^{3}\end{array}$} \\
\cline { 2 - 7 } & Cycle 1 & Cycles 1 and 2 & Cycle 1 & Cycles 1 and 2 & Cycle 1 & Cycle 2 \\
\hline 1 & 915 & 915 & 567 & 563 & 0.7365 & 0.7555 \\
2 & 968 & 968 & 565 & 561 & 0.7407 & 0.7595 \\
4 & 1015 & 1015 & 557 & 553 & 0.7554 & 0.7730 \\
7 & 1001 & 1001 & 543 & 540 & 0.7795 & 0.7953 \\
9 & 927 & 927 & 537 & 534 & 0.7885 & 0.8032 \\
\hline
\end{tabular}


Power histories for each sample are listed in Table 8. The burnup given in this table is the burnup at discharge and was determined experimentally from the measured ${ }^{148} \mathrm{Nd}$ concentration. Although burnup estimates were also experimentally determined by other methods, burnup data based on ${ }^{148} \mathrm{Nd}$ measurements were applied in this study for consistency with burnup estimates performed in earlier validation calculations. ${ }^{9}$ The specific powers for each depletion period were calculated using the burnup for each sample and the relative power in each period inferred from the period burnups given in Table 5 .

SAS2H input cases for each of the 14 Trino Vercelles fuel samples are given in Appendix B. These input cases are for calculations using the SCALE 27-group burnup library, known within SCALE as "27BURNUPLIB." Calculations were also performed using the SCALE "44GROUPNDF5" cross-section library, using identical input with the exception of the crosssection library specification, and the material specification for Zircaloy (which must be specified explicitly by nuclide for the 44-group library in SCALE-4.2). Light-element masses were computed based on the assembly's Zircaloy content. (Note: Input specifications for the cadmium component of the Trino Vercelles absorber rods were found to contain an error after completion of these calculations. The error is corrected in the Appendix B listings. The effect of this error was subsequently determined to be negligible. The nature and effect of this error are discussed in Appendix F.)

\subsection{TURKEY POINT UNIT 3 SPENT FUEL DEPLETION MODELS}

The Turkey Point Unit 3 PWR, operated by Florida Power and Light Co., was designed by Westinghouse Electric Corp. The fuel assembly design is based on a $15 \times 15$ square lattice, with 21 positions containing control rod and instrumentation guide tubes. Design and operating parameters ${ }^{15,16,21,22}$ providing the key relevant characteristics of the reactor, fuel, and fuel assembly configurations are given in Table 9.

Radiochemical assay data obtained from the analysis of two fuel assemblies, identified as D01 and D04, were used as a basis for models developed in this study. The initial fuel isotopic compositions for each of the two assemblies is given in Table 10. Initial ${ }^{235} \mathrm{U}$ and ${ }^{238} \mathrm{U}$ enrichments were given in available references; initial ${ }^{234} \mathrm{U}$ and ${ }^{236} \mathrm{U}$ concentrations were estimated using 
Table 8. Fuel burnup and operating power histories for Trino Vercelles PWR pellet samples

\begin{tabular}{|c|c|c|c|c|c|c|c|}
\hline Assembly ID & $509-104$ & $509-032$ & $509-032$ & $509-032$ & $509-069$ & $509-069$ & $509-069$ \\
\hline Fuel rod location & M11 & E11 & E11 & E11 & E11 & E11 & E11 \\
\hline Axial level no. & 7 & 4 & 7 & & & 2 & 4 \\
\hline Burnup, ${ }^{a} \mathrm{GWd} / \mathrm{MTU}$ & 12.042 & 15.377 & 15.898 & 11.529 & $12.859^{b}$ & 20.602 & 23.718 \\
\hline \multicolumn{8}{|l|}{ Powers, ${ }^{c} \mathrm{MW} / \mathrm{MTU}$ : } \\
\hline Cycle 1, Period I & 10.390 & 13.268 & 13.717 & 9.947 & 7.148 & 11.452 & 13.184 \\
\hline Cycle 1, Period II & 16.138 & 20.607 & 21.309 & 15.451 & 11.101 & 17.786 & 20.476 \\
\hline Cycle 1, Period III & 18.663 & 23.831 & 24.639 & 17.868 & 12.840 & 20.571 & 23.683 \\
\hline Cycle 2 & - & - & - & - & 10.997 & 17.619 & 20.283 \\
\hline Assembly ID & $509-069$ & $509-069$ & $509-069$ & $509-069$ & $509-069$ & $509-069$ & $509-069$ \\
\hline Fuel rod location & E11 & E5 & E5 & L11 & L11 & L5 & L5 \\
\hline Axial level no. & 7 & 4 & 7 & 4 & 7 & 4 & 7 \\
\hline Burnup, ${ }^{a} \mathrm{GWd} / \mathrm{MTU}$ & 24.304 & 23.867 & 24.548 & 23.928 & 24.362 & 24.330 & $24.313^{b}$ \\
\hline \multicolumn{8}{|l|}{ Powers, ${ }^{c}$ W/MTU: } \\
\hline Cycle 1, Period I & 13.509 & 13.266 & 13.645 & 13.300 & 13.542 & 13.524 & 13.514 \\
\hline Cycle 1, Period II & 20.982 & 20.605 & 21.193 & 20.657 & 21.032 & 21.004 & 20.990 \\
\hline Cycle 1, Period III & 24.268 & 23.832 & 24.512 & 23.893 & 24.326 & 24.294 & 24.277 \\
\hline Cycle 2 & 20.785 & 20.411 & 20.993 & 20.463 & 20.834 & 20.807 & 20.792 \\
\hline
\end{tabular}

${ }^{a}$ Burnup based on measured ${ }^{148} \mathrm{Nd}$ concentration, unless otherwise specified.

${ }^{6}$ Burnup based on measured ${ }^{137} \mathrm{Cs}$ concentration because there was no analysis of ${ }^{148} \mathrm{Nd}$ for the sample.

Powers determined from the above burnups and the specified uptimes and burnup distributions in Table 5. 


\begin{tabular}{l|l}
\hline \multicolumn{1}{c|}{ Parameter } & \multicolumn{1}{c}{ Data } \\
\hline Assembly general data & Westinghouse \\
Designer & $15 \times 15$ \\
Lattice & 204 \\
Number of fuel rods & 20 \\
Number of guide tubes & 1 \\
Number of instrument tubes & 2083 \\
Average 3-cycle water pressure, psia & $570(567)$ \\
Water temperature at sample axial location, K ( $\left.{ }^{\circ} \mathrm{F}\right)$ & 0.731 \\
Water density at sample axial location, $\mathrm{g} / \mathrm{cm}^{3}$ & 450 \\
Soluble boron, cycle average, ppm (wt) & 456.9 \\
Assembly mass, $\mathrm{kg}$ UO & \\
& \\
Fuel rod data & \\
Type fuel pellet & $\mathrm{UO}{ }_{2}$ \\
Stack density with gap, g/cm ${ }^{3}(\% \mathrm{TD})$ & $10.235(93.38)$ \\
Rod pitch, cm (in.) & $1.4300(0.563)$ \\
Rod OD, cm (in.) & $1.0719(0.422)$ \\
Rod ID, cm (in.) & $0.9484(0.3734)$ \\
Pellet OD, cm (in.) & $0.9296(0.366)$ \\
Active fuel length, cm (in.) & $365.76(144)$ \\
Effective fuel temperature, K & 922 \\
Clad material & Zircaloy-4 \\
Clad temperature, K & 595 \\
& \\
Guide tube data & \\
Inner radius, cm (ID as in.) & $0.6502(0.512)$ \\
Outer radius, cm (OD as in.) & $0.6934(0.546)$ \\
Tube material & Zircaloy-4 \\
\hline
\end{tabular}

${ }^{a}$ Sources: refs. 15, 16, 21, and 22.

Table 10. Initial composition of Turkey Point fuel assemblies

\begin{tabular}{l|c|c}
\hline \multirow{2}{*}{$\begin{array}{l}\text { Uranium } \\
\text { isotope }\end{array}$} & D01 & Assembly ID \\
\cline { 2 - 3 } & 2.556 & D04 \\
\hline wt \% ${ }^{235} \mathrm{U}$ & 0.023 & 2.556 \\
wt $\%{ }^{234} \mathrm{U}$ & 0.012 & 0.023 \\
wt $\%{ }^{236} \mathrm{U}$ & 97.409 & 0.012 \\
wt \% ${ }^{238} \mathrm{U}$ & & 97.409 \\
\hline
\end{tabular}


empirical relationships. ${ }^{21}$ Both assemblies were present in the reactor during fuel cycles 2 through 4; cycle lengths and downtimes are shown in Table 11. In the spent fuel assays, a single sample was taken from each of five different rods; all samples were taken from a location of either 167.0 or $167.6 \mathrm{~cm}$ above the bottom of the fuel, as shown in Table 1. The assembly, rod identification, and burnup for each sample are supplied in Table 12. Figure 3 shows the configuration of the $15 \times 15$ assembly design and illustrates the position of each of the fuel sample pin locations within the assembly. As with the Trino Vercelles measurements and those reported in ref. 9, burnups for the Turkey Point fuel samples were determined based on measured ${ }^{148} \mathrm{Nd}$ concentrations. No data were available indicating the operating power for the assemblies or core on a cycle-by-cycle basis. However, other fuel assemblies for which power histories were available during cycles 2 through 4 varied by less than $8 \%$ from the average power. ${ }^{15}$ Thus it was assumed that the reactor was operated at a constant power over all three cycles; average specific power was then computed for each sample based on the total length of the three cycles and the final burnup of the sample. These average powers are also given in Table 12 .

The 1-D assembly model for the Turkey Point assemblies was developed assuming a waterfilled guide tube surrounded by a cell-equivalent volume of water, surrounded in turn by the equivalent material corresponding to a homogenized fuel-pin cell. Since the full assembly consisted of 21 guide tubes intermixed with fuel cells, the 1-D approximation was based on a single guide tube cell surrounded by the volume equivalent of 9.714 fuel cells. This value was obtained as the ratio of fuel pins to water holes (204/21). This proportion results in the same water cell to fuel cell ratio as existed in the actual assembly.

SAS2H input cases for each of the five Turkey Point fuel samples are given in Appendix C. These input cases are for calculations using the SCALE 27-group burnup library, known within SCALE as "27BURNUPLIB." Calculations were also performed using the SCALE "44GROUPNDF5" cross-section library, using identical input with the exception of the crosssection library specification and the material specification for Zircaloy. 
Table 11. Turkey Point Unit 3 operating history of assemblies D01 and D04

\begin{tabular}{c|c|c|c|c}
\hline Cycle & Cycle start & Cycle end & Uptime, d & Downtime, d \\
\hline 2 & $12 / 16 / 74$ & $10 / 26 / 75$ & 314 & 58 \\
3 & $12 / 23 / 75$ & $11 / 15 / 76$ & 327 & 62 \\
4 & $1 / 16 / 77$ & $11 / 24 / 77$ & 312 & $927^{b}$ \\
\hline
\end{tabular}

${ }^{2}$ Florida Power and Light Co. data provided by E. R. Knuckles.

${ }^{b}$ Cooling time from shutdown to date of radiochemical analyses.

Table 12. Turkey Point pellet sample data

\begin{tabular}{l|c|c|c|c}
\hline $\begin{array}{l}\text { Assembly } \\
\text { ID }\end{array}$ & $\begin{array}{c}\text { Rod } \\
\text { column }\end{array}$ & $\begin{array}{c}\text { Rod } \\
\text { row }\end{array}$ & $\begin{array}{c}\text { Burnup, } \\
\text { GWd/MTU }\end{array}$ & $\begin{array}{c}\text { Power (avg.), } \\
\text { MW/MTU }\end{array}$ \\
\hline D01 & G & 9 & 30.720 & 32.235 \\
D01 & G & 10 & 30.510 & 32.015 \\
D01 & H & 9 & 31.560 & 33.116 \\
D04 & G & 9 & 31.260 & 32.802 \\
D04 & G & 10 & 31.310 & 32.854 \\
\hline
\end{tabular}




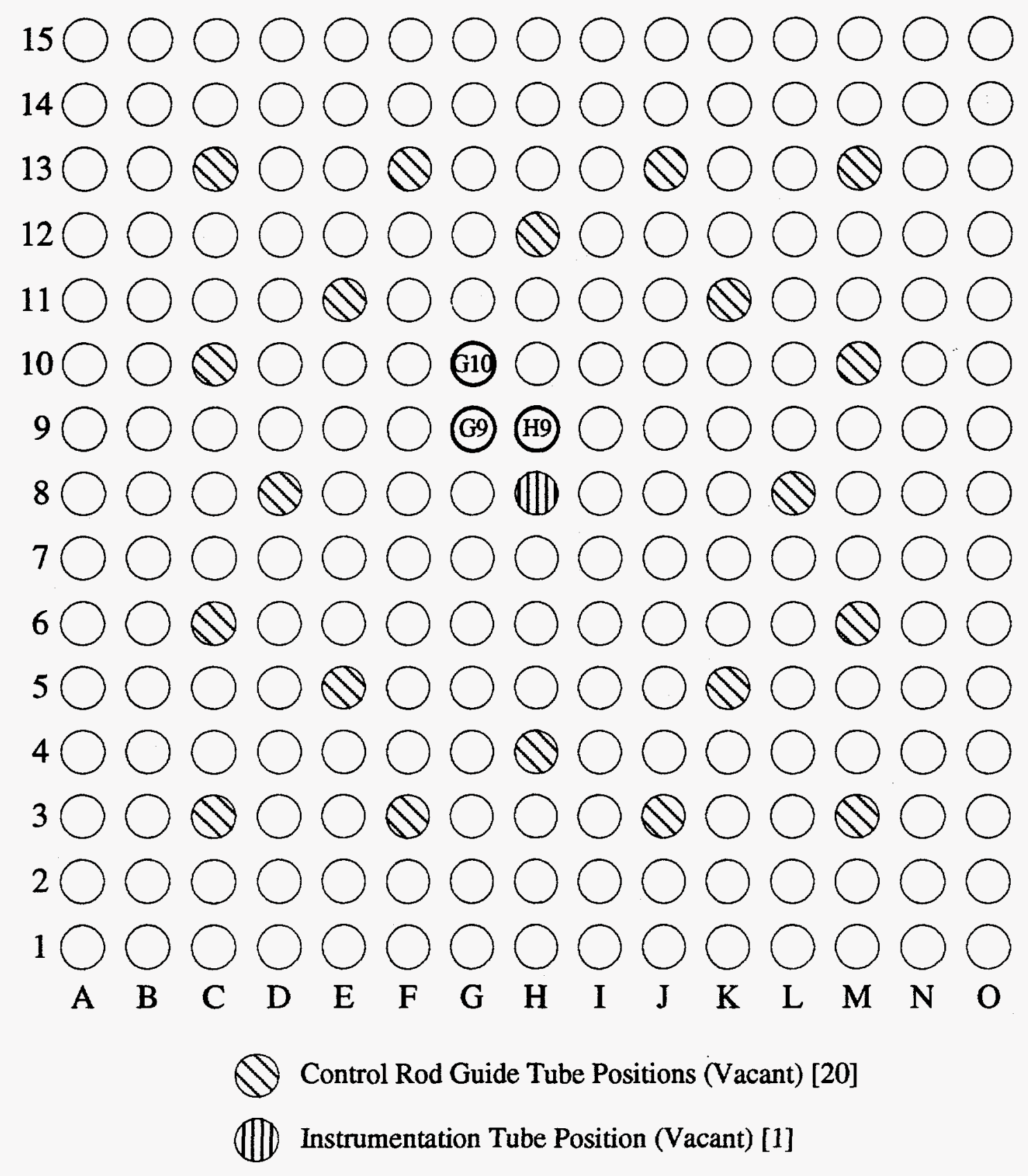

Fig. 3. $15 \times 15$ assembly configuration for Turkey Point Unit 3 PWR. 


\section{PREDICTED AND MEASURED ISOTOPIC COMPOSITIONS}

Comparisons of spent PWR fuel isotopic compositions predicted by SCALE-4 calculations to those measured by radiochemical assay analyses are provided in this section. Percentage differences between the computed and measured values for all isotopes selected for assay analysis are given for each sample. Also included in this section are the average percentage differences for each of the two reactor types, both for the set of analyses included in this study and for the combined results for this and earlier ${ }^{9}$ validation analyses. Comparisons are made based on results obtained using the two different SCALE cross-section libraries described in Sect. 1: the SCALE 27-group burnup library (27BURNUPLIB), and the SCALE 44-group library (44GROUPNDF5). Additional comparisons listing measurements, computed predictions, and percentage differences for each isotope of each sample are included in Appendix D for Trino Vercelles and Appendix E for Turkey Point Unit 3.

\subsection{TRINO VERCELLES PWR ISOTOPIC RESULTS}

Radiochemical nuclide analyses of the Trino Vercelles spent fuel samples were conducted by the Ispra and Karlsruhe facilities of the Joint Research Center. Thirty-nine samples from 14 different fuel rods were analyzed at one or both facilities; approximately half of the cases selected in this study were analyzed at both laboratories. Isotopic concentrations for all the major uranium and plutonium nuclides were measured by both laboratories for most samples. The average concentrations measured for the 14 samples selected for this study are listed in Table 13. This table also indicates the isotopes and samples for which only a single measurement was performed. The compositions were reported in several different types of units; each type of reported concentration is included in the table. However, all data were converted to units of milligrams per initial gram of uranium or curies per initial gram of uranium for consistency with the previous validation study. Measured (sample average) and computed nuclide concentrations are listed in these units in Appendix D for all Trino Vercelles samples. 
Table 13. Average measured irradiation composition ${ }^{a}$ of Trino Vercelles PWR fuel

\begin{tabular}{|c|c|c|c|c|c|c|c|c|}
\hline \multicolumn{2}{|c|}{$\begin{array}{l}\text { Assembly ID } \\
\text { Fuel rod ID } \\
\text { Sample height, level number } \\
\text { Burnup, }{ }^{b} \mathrm{GWd} / \mathrm{MTU}\end{array}$} & $\begin{array}{l}509-104 \\
\text { M11 } \\
7 \\
12.042\end{array}$ & $\begin{array}{l}509-032 \\
\text { E11 } \\
4 \\
15.377^{\circ}\end{array}$ & $\begin{array}{l}509-032 \\
\text { E } 11 \\
7 \\
15.898^{e}\end{array}$ & $\begin{array}{l}509-032 \\
\text { E11 } \\
9 \\
11.529^{\circ}\end{array}$ & $\begin{array}{l}509-069 \\
\mathrm{E} 11 \\
1 \\
12.859^{e}\end{array}$ & $\begin{array}{l}509-069 \\
\text { E11 } \\
2 \\
20.602\end{array}$ & $\begin{array}{l}509-069 \\
\text { E11 } \\
4 \\
23.718\end{array}$ \\
\hline Nuclide & Units of reported analysis & & & & & & & \\
\hline $\begin{array}{l}{ }^{235} \mathrm{U} \\
{ }^{236} \mathrm{U} \\
{ }^{238} \mathrm{U} \\
{ }^{239} \mathrm{Pu}^{d} \\
{ }^{240} \mathrm{Pu} \\
{ }^{241} \mathrm{Pu} \\
{ }^{242} \mathrm{Pu} \\
{ }^{242} \mathrm{Pu} \\
{ }^{242 m} \mathrm{Am} \\
{ }^{243} \mathrm{Am} \\
{ }^{242} \mathrm{Cm} \\
{ }^{244} \mathrm{Cm} \\
{ }^{106} \mathrm{Ru} \\
{ }^{134} \mathrm{Cs} \\
{ }^{137} \mathrm{Cs} \\
{ }^{144} \mathrm{Ce} \\
{ }^{148} \mathrm{Nd} \\
{ }^{154} \mathrm{Eu}\end{array}$ & 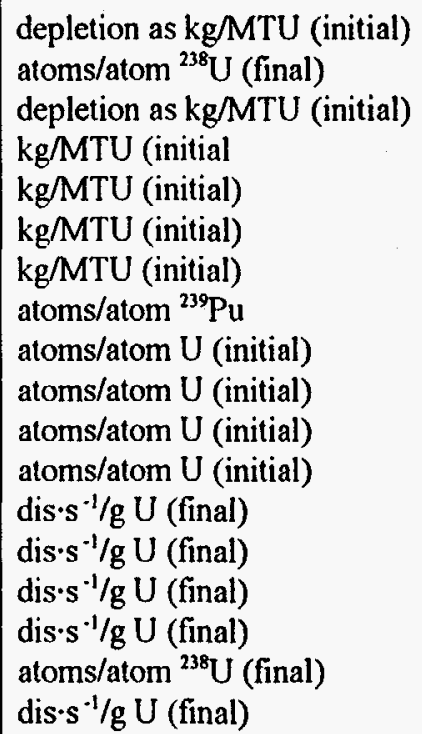 & $\begin{array}{l}1.2345 \times 10^{1} \\
2.900 \times 10^{-3} \\
\overline{4} \\
4.586 \\
7.165 \times 10^{-1} \\
3.475 \times 10^{-1} \\
\overline{6} \\
6.750 \times 10^{-3} \\
- \\
- \\
- \\
\overline{5.291 \times 10^{9 e}} \\
1.029 \times 10^{9 e} \\
1.469 \times 10^{9 e} \\
2.179 \times 10^{10 e} \\
- \\
-\end{array}$ & $\begin{array}{l}1.402 \times 10^{1 e} \\
2.990 \times 10^{-3 e} \\
- \\
5.266^{e} \\
1.118^{e} \\
6.140 \times 10^{-1 e} \\
- \\
1.620 \times 10^{-2 e} \\
- \\
- \\
- \\
- \\
8.029 \times 10^{9 e} \\
1.765 \times 10^{9 e} \\
1.876 \times 10^{9 e} \\
2.716 \times 10^{10 e} \\
- \\
-\end{array}$ & $\begin{array}{l}1.469 \times 10^{1 e} \\
2.890 \times 10^{-3 e} \\
\overline{5.234^{\circ}} \\
1.137^{\circ} \\
6.180 \times 10^{.1 e} \\
\overline{1} \\
1.790 \times 10^{-2 e} \\
- \\
- \\
- \\
\overline{8} .584 \times 10^{9 e} \\
1.869 \times 10^{9 e} \\
1.902 \times 10^{9 e} \\
2.660 \times 10^{10 e} \\
- \\
-\end{array}$ & $\begin{array}{l}1.113 \times 10^{1 e} \\
2.630 \times 10^{-3 e} \\
- \\
4.418^{e} \\
7.550 \times 10^{-1 e} \\
3.690 \times 10^{-1 e} \\
- \\
8.500 \times 10^{-3 e} \\
- \\
- \\
- \\
- \\
5.846 \times 10^{9 e} \\
1.021 \times 10^{9 e} \\
1.369 \times 10^{9 e} \\
2.098 \times 10^{10 e} \\
- \\
-\end{array}$ & $\begin{array}{l}1.184 \times 10^{1 e} \\
2.580 \times 10^{-3 e} \\
9.610^{\circ} \\
4.580^{e} \\
8.400 \times 10^{-1 e} \\
4.000 \times 10^{-1 e} \\
4.600 \times 10^{-2 e} \\
- \\
- \\
- \\
- \\
- \\
- \\
9.410 \times 10^{8 e} \\
1.486 \times 10^{9 e} \\
- \\
- \\
5.170 \times 10^{7 e}\end{array}$ & $\begin{array}{l}1.694 \times 10^{1} \\
3.515 \times 10^{-3} \\
1.6495 \times 10^{1} \\
5.755 \\
1.520 \\
8.850 \times 10^{-1} \\
1.720 \times 10^{-1} \\
- \\
1.365 \times 10^{-6} \\
2.345 \times 10^{-5} \\
1.740 \times 10^{-5} \\
4.560 \times 10^{-6} \\
- \\
2.312 \times 10^{9 e} \\
2.418 \times 10^{9 e} \\
- \\
3.900 \times 10^{-45} \\
1.398 \times 10^{8 e}\end{array}$ & $\begin{array}{l}1.882 \times 10^{1} \\
3.835 \times 10^{-3} \\
1.894 \times 10^{1} \\
5.895 \\
1.755 \\
1.030 \\
2.435 \times 10^{-1} \\
- \\
2.090 \times 10^{-65} \\
4.440 \times 10^{-55} \\
2.395 \times 10^{-5} \\
8.795 \times 10^{-6} \\
- \\
2.914 \times 10^{98} \\
2.775 \times 10^{96} \\
- \\
4.500 \times 10^{-4 f} \\
1.779 \times 10^{84}\end{array}$ \\
\hline
\end{tabular}


Table 13 (continued)

\begin{tabular}{|c|c|c|c|c|c|c|c|c|}
\hline \multicolumn{2}{|c|}{$\begin{array}{l}\text { Assembly ID } \\
\text { Fuel rod ID } \\
\text { Sample height, level number } \\
\text { Bumup, }{ }^{b} \text { GWd/MTU }\end{array}$} & $\begin{array}{l}509-069 \\
\text { E11 } \\
7 \\
24.304\end{array}$ & $\begin{array}{l}509-069 \\
\text { E5 } \\
4 \\
23.867^{\circ}\end{array}$ & $\begin{array}{l}509-069 \\
\text { ES } \\
7 \\
24.548\end{array}$ & $\begin{array}{l}509-069 \\
\mathrm{~L} 11 \\
4 \\
23.928^{\circ}\end{array}$ & $\begin{array}{l}509-069 \\
\text { L11 } \\
7 \\
24.362 \\
\end{array}$ & $\begin{array}{l}509-069 \\
\text { L5 } \\
4 \\
24.330^{e}\end{array}$ & $\begin{array}{l}509-069 \\
\text { L5 } \\
7 \\
24.313^{C}\end{array}$ \\
\hline Nuclide & Units of reported analysis & & & & & & & \\
\hline $\begin{array}{l}{ }^{235} \mathrm{U} \\
{ }^{236} \mathrm{U} \\
{ }^{238} \mathrm{U} \\
{ }^{239} \mathrm{Pu} \\
{ }^{240} \mathrm{Pu} \\
{ }^{241} \mathrm{Pu} \\
{ }^{242} \mathrm{Pu} \\
{ }^{242 m} \mathrm{Am} \\
{ }^{243} \mathrm{Am} \\
{ }^{242} \mathrm{Cm} \\
{ }^{244} \mathrm{Cm} \\
{ }^{106} \mathrm{Ru} \\
{ }^{134} \mathrm{Cs} \\
{ }^{139} \mathrm{Cs} \\
{ }^{144} \mathrm{Ce} \\
{ }^{148} \mathrm{Nd} \\
{ }^{154} \mathrm{Eu}\end{array}$ & 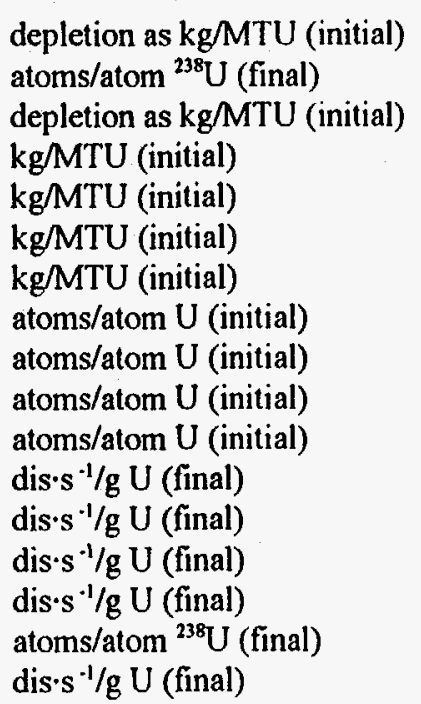 & $\begin{array}{l}1.8955 \times 10^{1} \\
3.865 \times 10^{-3} \\
1.912 \times 10^{1} \\
6.070 \\
1.825 \\
1.060 \\
2.575 \times 10^{-1} \\
2.220 \times 10^{-65} \\
4.490 \times 10^{-5 f} \\
2.620 \times 10^{-9} \\
9.660 \times 10^{-6} \\
- \\
2.987 \times 10^{9 e} \\
2.818 \times 10^{9 e} \\
- \\
4.610 \times 10^{-4 f} \\
1.650 \times 10^{8 e}\end{array}$ & $\begin{array}{l}1.839 \times 10^{1 e} \\
3.740 \times 10^{-3 e} \\
1.913 \times 10^{1 e} \\
5.950^{e} \\
1.760^{e} \\
1.050^{e} \\
2.400 \times 10^{-1 e} \\
- \\
- \\
2.280 \times 10^{-5 e} \\
8.740 \times 10^{-6 e} \\
\overline{2.939 \times 10^{9 e}} \\
2.788 \times 10^{9 e} \\
\overline{4} .520 \times 10^{-4 e} \\
1.765 \times 10^{8 e}\end{array}$ & $\begin{array}{l}1.909 \times 10^{1} \\
3.765 \times 10^{-3} \\
1.9955 \times 10^{1} \\
5.980 \\
1.785 \\
1.055 \\
2.540 \times 10^{-1} \\
2.400 \times 10^{-6} \\
4.520 \times 10^{-5} \\
2.470 \times 10^{-5} \\
9.190 \times 10^{-6} \\
- \\
3.054 \times 10^{9 e} \\
2.909 \times 10^{9 e} \\
- \\
4.650 \times 10^{-45} \\
1.919 \times 10^{8 e}\end{array}$ & $\begin{array}{l}1.848 \times 10^{\mathrm{V}} \\
3.990 \times 10^{-35} \\
1.980 \times 10^{\mathrm{V}} \\
6.060^{\prime} \\
1.790^{\prime} \\
1.050^{\prime} \\
2.470 \times 10^{-65} \\
1.930 \times 10^{-6 f} \\
4.360 \times 10^{-5 f} \\
2.750 \times 10^{-5 f} \\
8.930 \times 10^{-65} \\
- \\
- \\
- \\
- \\
4.540 \times 10^{-4 f} \\
-\end{array}$ & $\begin{array}{l}1.905 \times 10^{1} \\
3.685 \times 10^{-3} \\
2.010 \times 10^{1} \\
5.995 \\
1.810 \\
1.055 \\
2.590 \times 10^{-1} \\
2.155 \times 10^{-6} \\
4.160 \times 10^{-5} \\
2.425 \times 10^{-5} \\
9.495 \times 10^{-6} \\
- \\
3.048 \times 10^{9 e} \\
2.881 \times 10^{9 e} \\
- \\
4.620 \times 10^{-4 e} \\
1.718 \times 10^{8 e}\end{array}$ & $\begin{array}{l}1.833 \times 10^{1 e} \\
3.690 \times 10^{-3 e} \\
1.960 \times 10^{1 e} \\
6.060^{e} \\
1.770^{e} \\
1.060^{\circ} \\
2.440 \times 10^{-16} \\
- \\
- \\
2.480 \times 10^{-5 e} \\
9.290 \times 10^{-6 e} \\
\overline{2.939 \times 10^{96}} \\
2.821 \times 10^{9 e} \\
\overline{4} \\
4.590 \times 10^{-4 e} \\
1.768 \times 10^{8 e}\end{array}$ & $\begin{array}{l}1.899 \times 10^{10} \\
3.800 \times 10^{-3 \mathrm{e}} \\
2.109 \times 10^{1 \mathrm{e}} \\
5.970^{\circ} \\
1.790^{\circ} \\
1.060^{\circ} \\
2.500 \times 10^{-1 \mathrm{e}} \\
- \\
- \\
2.440 \times 10^{-5 e} \\
8.570 \times 10^{-6 \mathrm{e}} \\
- \\
3.005 \times 10^{96} \\
2.862 \times 10^{9 \mathrm{e}} \\
- \\
- \\
1.849 \times 10^{8 \mathrm{ee}}\end{array}$ \\
\hline
\end{tabular}

${ }^{\circ}$ Adjusted to the shutdown composition, except for ${ }^{239} \mathrm{Pu}$.

${ }^{b}$ Burnup, based on measured ${ }^{148} \mathrm{Nd}$ concentration, unless otherwise specified.

'Bumup, based on measured ${ }^{137} \mathrm{Cs}$ concentration.

${ }^{d}$ Compositions of ${ }^{239} \mathrm{Pu}$ include ${ }^{239} \mathrm{U}$ and ${ }^{239} \mathrm{~Np}$ at shutdown. Source: Ref. 12.

'Measured at Ispra only.

Measured at Karlsruhe only. 
The percentage differences between measured and calculated concentrations for each isotope of each sample are given in Tables 14 and 15 for the results of calculations using the 27-group and the 44-group cross-section libraries, respectively. These tables also provide the average difference for all samples.

As was noted earlier, an error was identified in the specification of the absorber rod contents for all Trino Vercelles calculations, and has an effect on the values reported in Tables 14 and 15 . However, the effect is very minor and may be neglected. The nature of the error and its effect are described in Appendix F.

\subsection{TURKEY POINT UNIT 3 PWR ISOTOPIC RESULTS}

Radiochemical isotopic analyses of five pellet samples from two spent fuel assemblies of the Turkey Point Unit 3 PWR were analyzed by BCL for the Climax Spent Fuel Test. ${ }^{15}$ The measured post-irradiation nuclide concentrations are listed in Table 16 as reported, in terms of atomic percentages or as ratios to ${ }^{238} \mathrm{U}$ atomic content. Again, the concentration data were converted to units of milligrams of the nuclide per gram of initial uranium; measured and computed concentrations are given in these units in Appendix $\mathrm{E}$ for all Turkey Point samples. The percentage differences between measured and calculated concentrations for each isotope of each sample are given in Tables 17 and 18 for the results of calculations using the 27-group and the 44-group crosssection libraries, respectively. These tables also provide the average difference for all samples.

\subsection{SUMMARY OF COMBINED ISOTOPIC RESULTS}

Average percentage differences between measured and computed isotopic concentrations combined from both Trino Vercelles and Turkey Point data are given in Table 19. This table also provides the number of samples used to calculate the average and the minimum and maximum differences for all cases. These results are also illustrated in Figs. 4 and 5 for 27 -group and 44-group results, respectively. The results for all samples described herein were combined with those reported in ref. 9; Table 20 summarizes averages from the current study, the earlier study, and the combined average, for both cross-section libraries. Figures 6 and 7 illustrate the results for the combined samples for each isotope for 27-group and 44-group results, respectively. 
Table 14. Percentage difference between measured and computed nuclide compositions for Trino Vercelles PWR samples and averages (27BURNUPLIB library)

\begin{tabular}{|c|c|c|c|c|c|c|c|c|c|c|c|c|c|c|c|}
\hline \multirow{2}{*}{$\begin{array}{l}\text { Assembly } \\
\left(\text { wt } \%{ }^{235} \mathrm{U}\right) \\
\text { Burnup, } \\
\text { GWd/MTU }\end{array}$} & \multirow{2}{*}{$\begin{array}{c}\begin{array}{c}509-104 \\
(3.897)\end{array} \\
12.042\end{array}$} & \multicolumn{3}{|c|}{$\begin{array}{c}509-032 \\
(3.13)\end{array}$} & \multicolumn{10}{|c|}{$\begin{array}{c}509-069 \\
(3.13)\end{array}$} & \multirow{2}{*}{ Average } \\
\hline & & 15.377 & 15.898 & 11.529 & 12.859 & 20.602 & 23.718 & 24.304 & 23.867 & 24.548 & 23.928 & 24.362 & 24.330 & 24.313 & \\
\hline$\frac{\text { Nuclide }}{{ }^{235} \mathrm{U}}$ & 12 & 34 & & & & & & & & & & & & & \\
\hline${ }^{236} \mathrm{U}$ & -10.4 & $\begin{array}{r}5.4 \\
-7.8\end{array}$ & $\begin{array}{r}J .1 \\
-2.4\end{array}$ & $\begin{array}{r}1.4 \\
-14.5\end{array}$ & $\begin{array}{l}-0.1 \\
-5.4\end{array}$ & $\begin{array}{r}1.9 \\
-5.0\end{array}$ & $\begin{array}{r}3.8 \\
-5.5\end{array}$ & $\begin{array}{r}1.7 \\
-4.9\end{array}$ & $\begin{array}{l}-0.2 \\
-2.8\end{array}$ & $\begin{array}{r}1.8 \\
-1.8\end{array}$ & $\begin{array}{r}0.2 \\
-8.7\end{array}$ & $\begin{array}{r}2.2 \\
-0.1\end{array}$ & $\begin{array}{l}-2.4 \\
-0.4\end{array}$ & $\begin{array}{r}1.9 \\
-3.1\end{array}$ & $\begin{array}{r}1.6 \\
-5.2\end{array}$ \\
\hline${ }^{238} \mathrm{U}$ & 0.1 & $<0.1$ & $<0.1$ & $<0.1$ & -0.1 & $<0.1$ & $<0.1$ & $<0.1$ & $<0.1$ & $<0.1$ & $<0.1$ & 0.1 & $<0.1$ & 0.2 & $<0.1$ \\
\hline${ }^{239} \mathrm{Pu}$ & -3.7 & -1.2 & -1.3 & -1.8 & 2.5 & 0.9 & 2.4 & -2.1 & 1.7 & -0.4 & -0.1 & -0.8 & 0.4 & -0.5 & -0.3 \\
\hline${ }^{240} \mathrm{Pu}$ & -7.0 & -4.4 & -3.1 & -4.0 & 1.7 & -3.6 & -4.1 & -6.2 & -3.8 & -3.2 & -5.2 & -5.3 & -2.6 & -4.4 & -3.9 \\
\hline${ }^{241} \mathrm{Pu}$ & -4.5 & 2.9 & 5.7 & -0.2 & 7.7 & 3.2 & 6.3 & 4.5 & 5.1 & 6.4 & 5.5 & 5.3 & 6.7 & 4.6 & 4.2 \\
\hline${ }^{242} \mathrm{Pu}$ & -19.2 & -11.3 & -12.3 & -12.6 & -3.4 & -8.3 & -8.5 & -8.5 & -5.8 & -5.0 & -7.9 & -8.5 & -3.0 & -5.6 & -8.6 \\
\hline${ }^{242 \mathrm{~m}} \mathrm{Am}$ & - & - & - & - & - & 60.4 & 23.4 & 15.3 & - & 7.8 & 35.0 & 19.1 & - & - & 26.8 \\
\hline${ }^{243} \mathrm{Am}$ & - & - & - & - & - & -4.2 & -18.0 & -13.4 & - & -11.0 & -14.0 & -5.8 & - & - & -11.1 \\
\hline${ }^{242} \mathrm{Cm}$ & - & - & - & - & - & -21.4 & -21.7 & -25.8 & -16.6 & -19.5 & -30.5 & -19.4 & -20.0 & -20.2 & -21.7 \\
\hline${ }^{244} \mathrm{Cm}$ & - & - & - & - & - & -27.5 & -28.4 & -29.2 & -25.8 & -22.0 & -26.5 & -27.1 & -23.7 & -20.0 & -25.6 \\
\hline${ }^{106} \mathrm{Ru}$ & -7.8 & 1.5 & -1.0 & -10.5 & - & - & - & - & - & - & - & - & - & - & -4.5 \\
\hline${ }^{134} \mathrm{Cs}$ & -23.3 & -19.5 & -19.9 & -23.0 & -23.3 & -20.2 & -16.8 & -15.7 & -37.7 & -15.8 & - & -16.9 & -13.3 & -15.9 & -20.1 \\
\hline${ }^{137} \mathrm{Cs}$ & 1.1 & 1.4 & 3.5 & 3.5 & 0.7 & 0.3 & 1.1 & 2.0 & 1.2 & -0.1 & - & 0.2 & 2.0 & 0.7 & 1.4 \\
\hline${ }^{144} \mathrm{Ce}$ & -2.6 & -3.9 & 1.5 & -5.0 & - & - & - & - & - & - & - & - & - & - & -2.5 \\
\hline${ }^{148} \mathrm{Nd}$ & - & - & - & - & - & -1.6 & -1.7 & -1.6 & -1.5 & -1.4 & -1.6 & -1.5 & -1.0 & - & -1.5 \\
\hline${ }^{154} \mathrm{Eu}$ & - & - & - & - & 8.7 & 13.0 & 19.0 & 33.6 & 21.5 & 17.4 & - & 29.1 & 26.2 & 19.6 & 20.9 \\
\hline
\end{tabular}

"(Calculated/measured -1$) \times 100 \%$.

'Using SAS2H/ORIGEN-S analysis sequence and 27-group cross-section library of SCALE-4. 
Table 15. Percentage difference ${ }^{a}$ between measured and computed ${ }^{b}$ nuclide compositions for Trino Vercelles PWR samples and averages (44GROUPNDF5 library)

\begin{tabular}{|c|c|c|c|c|c|c|c|c|c|c|c|c|c|c|c|}
\hline \multirow{2}{*}{$\begin{array}{l}\text { Assembly } \\
\left.\text { (wt \% }{ }^{235} \mathrm{U}\right) \\
\text { Burmup, } \\
\text { GWd/MTU }\end{array}$} & \multirow{2}{*}{$\begin{array}{c}509-004 \\
(3.897) \\
12.042\end{array}$} & \multicolumn{3}{|c|}{$\begin{array}{c}509-032 \\
(3.13)\end{array}$} & \multicolumn{10}{|c|}{$\begin{array}{c}509-069 \\
(3.13)\end{array}$} & \multirow[t]{2}{*}{ Average } \\
\hline & & 15.377 & 15.898 & 11.529 & 12.859 & 20.602 & 23.718 & 24.304 & 23.867 & 24.548 & 23.928 & 24.362 & 24.330 & 24.313 & \\
\hline Nuclide & & & & & & & & & & & & & & & \\
\hline${ }^{235} \mathrm{U}$ & 1.2 & 3.9 & 4.8 & 1.3 & 0.5 & 2.5 & 4.5 & 1.0 & 0.5 & 1.1 & 1.0 & 1.5 & -1.7 & 1.2 & 1.7 \\
\hline${ }^{236} \mathrm{U}$ & -10.6 & -8.1 & -2.6 & -14.6 & -5.8 & -5.2 & -5.7 & -5.0 & $-3,0$ & -1.9 & -8.9 & -0.1 & -0.6 & -3.1 & -5.4 \\
\hline${ }^{238} \mathrm{U}$ & 0.1 & $<0.1$ & $<0.1$ & $<0.1$ & $<0.1$ & $<0.1$ & $<0.1$ & $<0.1$ & $<0.1$ & $<0.1$ & 0.1 & 0.1 & $<0.1$ & 0.2 & $<0.1$ \\
\hline${ }^{239} \mathrm{Pu}$ & -4.1 & -5.3 & -1.2 & -2.0 & -1.5 & -3.6 & -2.4 & -1.7 & -3.1 & $<0.1$ & -4.8 & -0.4 & -4.3 & -0.1 & -2.5 \\
\hline${ }^{240} \mathrm{Pu}$ & -6.4 & 1.7 & -1.8 & -3.5 & 8.2 & 2.3 & 1.6 & -4.4 & 1.9 & -1.3 & 0.5 & -3.4 & 3.2 & -2.5 & -0.3 \\
\hline${ }^{241} \mathrm{Pu}$ & -11.9 & -1.4 & -2.2 & -8.1 & 3.6 & -1.6 & 1.1 & -2.5 & $<0.1$ & -0.8 & 0.3 & -1.7 & 1.5 & -2.4 & -1.9 \\
\hline${ }^{242} \mathrm{Pu}$ & -14.5 & 1.6 & -7.4 & -8.6 & 10.3 & 4.0 & 3.5 & -2.9 & 6.6 & 0.8 & 4.2 & -2.9 & 9.8 & 0.1 & 0.3 \\
\hline${ }^{242 \mathrm{~m}} \mathrm{Am}$ & - & - & - & - & - & 19.3 & -9.0 & -19.4 & - & -24.6 & -0.5 & -16.7 & - & - & -8.5 \\
\hline${ }^{243} \mathrm{Am}$ & - & - & - & - & - & 7.3 & -8.7 & -10.3 & - & -7.8 & -4.2 & -2.4 & - & - & -4.3 \\
\hline${ }^{242} \mathrm{Cm}$ & - & - & - & - & - & -28.0 & -28.1 & -35.5 & $-23,4$ & -30.0 & -36.2 & -29.9 & -26.5 & -30.7 & -29.8 \\
\hline${ }^{244} \mathrm{Cm}$ & - & - & - & - & - & -9.6 & -11.6 & -19.4 & -8.5 & -11.3 & -9.4 & -17.1 & -6.0 & -9.0 & -11.3 \\
\hline${ }^{106} \mathrm{Ru}$ & -8.7 & 2.3 & -2.1 & -11.5 & - & - & - & - & - & - & - & - & - & - & -5.0 \\
\hline${ }^{134} \mathrm{Cs}$ & -26.0 & -22.5 & -22.7 & -25.5 & -25.9 & -23.2 & -20.1 & -18.7 & -40.2 & -18.8 & - & -19.9 & -16.7 & -19.0 & -23.0 \\
\hline${ }^{137} \mathrm{Cs}$ & 1.1 & 1.4 & 3.5 & 3.5 & 0.7 & 0.3 & 1.0 & 2.0 & 1.2 & -0.1 & - & 0.2 & 2.0 & 0.7 & 1.3 \\
\hline${ }^{144} \mathrm{Ce}$ & -2.5 & -4.0 & 1.6 & -4.9 & - & - & - & - & - & - & - & - & - & - & -2.4 \\
\hline${ }^{148} \mathrm{Nd}$ & - & - & - & - & - & -1.5 & -1.6 & -1.5 & -1.4 & -1.3 & -1.5 & -1.4 & -1.0 & - & -1.4 \\
\hline${ }^{154} \mathrm{Eu}$ & - & - & - & - & -25.6 & -26.2 & -23.8 & -12.8 & -22.3 & -23.5 & - & -15.8 & -19.4 & -22.0 & -21.3 \\
\hline
\end{tabular}

${ }^{a}($ Calculated/measured -1$) \times 100 \%$.

${ }^{b}$ Using SAS2H/ORIGEN-S analysis sequence and a 44-group ENDF/B-V cross-section library with data for ${ }^{154}$ Eu and ${ }^{135}$ Eu taken from ENDF/B-VI. 
Table 16. Measured irradiation composition ${ }^{a}$ of Turkey Point Unit 3 PWR fuel

\begin{tabular}{|c|c|c|c|c|c|}
\hline $\begin{array}{l}\text { Assembly ID } \\
\text { Fuel rod ID } \\
\text { Sample ID } \\
\text { Sample height, cm } \\
\text { Burnup, }{ }^{b} \mathrm{GWd} / \mathrm{MTU} \\
\text { Atom \% burnup }\end{array}$ & $\begin{array}{l}\text { D01 } \\
\text { G9 } \\
15 \\
167.6 \\
30.720 \\
3.200\end{array}$ & $\begin{array}{l}\text { D01 } \\
\text { G10 } \\
4 \\
167.0 \\
30.510 \\
3.179\end{array}$ & $\begin{array}{l}\text { D01 } \\
\text { H9 } \\
7 \\
167.0 \\
31.560 \\
3.288\end{array}$ & $\begin{array}{l}\text { D04 } \\
\text { G9 } \\
9 \\
167.6 \\
31.260 \\
3.256\end{array}$ & $\begin{array}{l}\text { D04 } \\
\text { G10 } \\
7 \\
167.0 \\
31.310 \\
3.262\end{array}$ \\
\hline $\begin{array}{l}{ }^{234} \mathrm{U} \text { atom } \% \\
{ }^{235} \mathrm{U} \text { atom } \% \\
{ }^{236} \mathrm{U} \text { atom } \% \\
{ }^{238} \mathrm{U} \text { atom } \% \\
{ }^{238} \mathrm{Pu} \text { atom } \% \\
{ }^{239} \mathrm{Pu} \text { atom } \% \\
{ }^{240} \mathrm{Pu} \text { atom } \% \\
{ }^{241} \mathrm{Pu} \text { atom } \% \\
{ }^{242} \mathrm{Pu} \text { atom } \% \\
{ }^{148} \mathrm{Nd} /{ }^{33} \mathrm{U} \text { atom ratio } \\
{ }^{239} \mathrm{Pu} /{ }^{238} \mathrm{U} \text { atom ratio }\end{array}$ & $\begin{array}{l}0.014 \\
0.619 \\
0.342 \\
99.025 \\
1.561 \\
55.107 \\
25.701 \\
11.984 \\
5.647 \\
5.66 \times 10^{-4} \\
5.07 \times 10^{-3}\end{array}$ & $\begin{array}{l}0.014 \\
0.599 \\
0.342 \\
99.045 \\
1.545 \\
54.757 \\
25.846 \\
11.988 \\
5.864 \\
5.62 \times 10^{-4} \\
5.07 \times 10^{-3}\end{array}$ & $\begin{array}{l}0.013 \\
0.590 \\
0.334 \\
99.063 \\
1.592 \\
54.806 \\
25.411 \\
12.177 \\
6.014 \\
5.82 \times 10^{-4} \\
5.17 \times 10^{-3}\end{array}$ & $\begin{array}{l}0.012 \\
0.582 \\
0.332 \\
99.074 \\
1.535 \\
54.654 \\
25.553 \\
12.329 \\
5.929 \\
5.76 \times 10^{-4} \\
5.18 \times 10^{-3}\end{array}$ & $\begin{array}{l}0.014 \\
0.598 \\
0.342 \\
99.046 \\
1.570 \\
54.574 \\
25.851 \\
12.113 \\
5.892 \\
5.77 \times 10^{-4} \\
5.02 \times 10^{-3}\end{array}$ \\
\hline
\end{tabular}

Radiochemical analyses conducted after a cooling time of 927 days.

${ }^{6}$ Based on measured ${ }^{148} \mathrm{Nd}$ concentration.

Per final ${ }^{238} \mathrm{U}$ atom. 
Table 17. Percentage difference ${ }^{a}$ between measured and computed ${ }^{b}$ nuclide compositions for Turkey Point Unit 3 PWR samples and averages (27BURNUPLIB library)

\begin{tabular}{|c|c|c|c|c|c|c|}
\hline \multirow{2}{*}{ 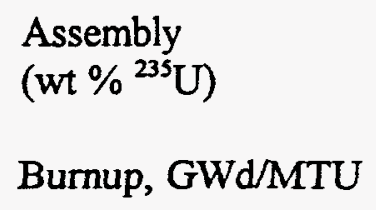 } & \multicolumn{3}{|c|}{$\begin{array}{c}\mathrm{D} 01 \\
(2.556)\end{array}$} & \multicolumn{2}{|c|}{$\begin{array}{c}\text { D04 } \\
(2.556)\end{array}$} & \multirow{2}{*}{ Average } \\
\hline & 30.720 & 30.510 & 31.560 & 31.260 & 31.310 & \\
\hline Nuclide & & & & & & \\
\hline${ }^{234} \mathrm{U}$ & 4.4 & 4.8 & 10.9 & 20.8 & 3.4 & 8.9 \\
\hline${ }^{235} \mathrm{U}$ & -7.1 & -2.9 & -7.1 & -4.2 & -7.0 & -5.6 \\
\hline${ }^{236} \mathrm{U}$ & 3.0 & 2.8 & 6.5 & 6.8 & 3.7 & 4.6 \\
\hline${ }^{238} \mathrm{U}$ & -0.1 & -0.1 & -0.1 & -0.1 & -0.1 & -0.1 \\
\hline${ }^{238} \mathrm{Pu}$ & 7.3 & 6.2 & 8.5 & 9.8 & 11.0 & 8.6 \\
\hline${ }^{239} \mathrm{Pu}$ & 5.0 & 4.9 & 3.3 & 3.0 & 6.3 & 4.5 \\
\hline${ }^{240} \mathrm{Pu}$ & -5.2 & -6.9 & -4.7 & -6.3 & -4.5 & -5.5 \\
\hline${ }^{241} \mathrm{Pu}$ & 9.4 & 8.1 & 7.4 & 4.7 & 10.0 & 7.9 \\
\hline${ }^{242} \mathrm{Pu}$ & 2.5 & -3.4 & -0.6 & -1.6 & 2.3 & -0.2 \\
\hline${ }^{148} \mathrm{Nd}$ & 1.6 & 1.6 & 1.6 & 1.6 & 1.6 & 1.6 \\
\hline
\end{tabular}

${ }^{a}($ Calculated/measured - 1) $\times 100 \%$.

${ }^{b}$ Using SAS2H/ORIGEN-S analysis sequence and 27-group cross-section library of SCALE-4. 
Table 18. Percentage difference ${ }^{a}$ between measured and computed ${ }^{b}$ nuclide compositions for Turkey Point Unit 3 PWR samples and averages (44GROUPNDF5 library)

\begin{tabular}{|c|c|c|c|c|c|c|}
\hline \multirow{2}{*}{$\begin{array}{l}\text { Assembly } \\
\text { (wt } \%{ }^{235} \mathrm{U} \text { ) } \\
\text { Burnup, GWd/MTU }\end{array}$} & \multicolumn{3}{|c|}{$\begin{array}{c}\text { D01 } \\
(2.556)\end{array}$} & \multicolumn{2}{|c|}{$\begin{array}{c}\text { D04 } \\
(2.556)\end{array}$} & \multirow{2}{*}{ Average } \\
\hline & 30.720 & 30.510 & 31.560 & 31.260 & 31.310 & \\
\hline \multicolumn{7}{|l|}{ Nuclide } \\
\hline${ }^{234} \mathrm{U}$ & 1.8 & 2.2 & 8.1 & 17.7 & 0.8 & 6.1 \\
\hline${ }^{235} \mathrm{U}$ & -5.8 & -1.5 & -5.7 & -2.8 & -5.7 & -4.3 \\
\hline${ }^{236} \mathrm{U}$ & 3.0 & 2.7 & 6.5 & 6.7 & 3.6 & 4.5 \\
\hline${ }^{238} \mathrm{U}$ & -0.1 & -0.1 & -0.1 & -0.1 & -0.1 & -0.1 \\
\hline${ }^{238} \mathrm{Pu}$ & 1.4 & 0.4 & 2.6 & 3.8 & 4.9 & 2.6 \\
\hline${ }^{239} \mathrm{Pu}$ & -0.6 & -0.7 & -2.3 & -2.6 & 0.6 & -1.1 \\
\hline${ }^{240} \mathrm{Pu}$ & 0.5 & -1.2 & 1.1 & -0.6 & 1.3 & 0.2 \\
\hline${ }^{241} \mathrm{Pu}$ & 2.8 & 1.6 & 0.9 & -1.6 & 3.3 & 1.4 \\
\hline${ }^{242} \mathrm{Pu}$ & 13.9 & 7.3 & 10.4 & 9.2 & 13.6 & 10.9 \\
\hline${ }^{148} \mathrm{Nd}$ & 1.7 & 1.6 & 1.6 & 1.7 & 1.7 & 1.7 \\
\hline
\end{tabular}

${ }^{a}($ Calculated/measured - 1) $\times 100 \%$.

${ }^{b}$ Using SAS2H/ORIGEN-S analysis sequence and 44-group cross-section library with data for ${ }^{154} \mathrm{Eu}$ and ${ }^{155} \mathrm{Eu}$ taken from ENDF/B-VI. 
Table 19. Summary of percentage differences ${ }^{\alpha}$ between measured and computed compositions in this study as averages and spreads

\begin{tabular}{|c|c|c|c|c|c|c|c|}
\hline \multirow[b]{2}{*}{ Nuclide } & \multirow{2}{*}{$\begin{array}{c}\text { Number } \\
\text { of } \\
\text { cases }\end{array}$} & \multicolumn{3}{|c|}{ 27BURNUPLIB data } & \multicolumn{3}{|c|}{ 44GROUPNDF5 data } \\
\hline & & Average & $\operatorname{Max}$ & Min & Average & $\operatorname{Max}$ & Min \\
\hline${ }^{234} \mathrm{U}$ & 5 & 8.9 & 20.8 & 3.4 & 6.1 & 17.7 & 0.8 \\
\hline${ }^{235} \mathrm{U}$ & 19 & -0.3 & 5.1 & -7.1 & 0.1 & 4.8 & -5.8 \\
\hline${ }^{236} \mathrm{U}$ & 19 & -2.6 & 6.8 & -14.5 & -2.8 & 6.7 & -14.6 \\
\hline${ }^{238} \mathrm{U}$ & 19 & $<0.1$ & 0.2 & -0.1 & $<0.1$ & 0.2 & -0.1 \\
\hline${ }^{238} \mathrm{Pu}$ & 5 & 8.6 & 11.0 & 6.2 & 2.6 & 4.9 & 0.4 \\
\hline${ }^{239} \mathrm{Pu}$ & 19 & 1.0 & 6.3 & -3.7 & -2.1 & 0.6 & -5.3 \\
\hline${ }^{240} \mathrm{Pu}$ & 19 & -4.4 & 1.7 & -7.0 & -0.2 & 8.2 & -6.4 \\
\hline${ }^{241} \mathrm{Pu}$ & 19 & 5.2 & 10.0 & -4.5 & -1.0 & 3.6 & -11.9 \\
\hline${ }^{242} \mathrm{Pu}$ & 19 & -6.3 & 2.5 & -19.2 & 3.1 & 13.9 & -14.5 \\
\hline${ }^{242 m} \mathrm{Am}$ & 6 & 26.8 & 60.4 & 7.8 & -8.5 & 19.3 & -24.6 \\
\hline${ }^{243} \mathrm{Am}$ & 6 & -11.1 & -4.2 & -18.0 & -4.3 & 7.3 & -10.3 \\
\hline${ }^{242} \mathrm{Cm}$ & 9 & -21.7 & -16.6 & -30.5 & -29.8 & -23.4 & -36.2 \\
\hline${ }^{244} \mathrm{Cm}$ & 9 & -25.6 & -20.0 & -29.2 & -11.3 & -6.0 & -19.4 \\
\hline${ }^{106} \mathrm{Ru}$ & 4 & -4.5 & 1.5 & -10.5 & -5.0 & 2.3 & -11.5 \\
\hline${ }^{134} \mathrm{Cs}$ & 13 & -20.1 & -13.3 & -37.7 & -23.0 & -16.7 & -40.2 \\
\hline${ }^{137} \mathrm{Cs}$ & 13 & 1.4 & 3.5 & -0.1 & 1.3 & 3.5 & -0.1 \\
\hline${ }^{144} \mathrm{Ce}$ & 4 & -2.5 & 1.5 & -5.0 & -2.4 & 1.6 & -4.9 \\
\hline${ }^{148} \mathrm{Nd}$ & 13 & -0.3 & 1.6 & -1.7 & -0.2 & 1.7 & -1.6 \\
\hline${ }^{154} \mathrm{Eu}$ & 9 & 20.9 & 33.6 & 8.7 & -21.3 & -12.8 & -26.2 \\
\hline
\end{tabular}

${ }^{a}($ Calculated $/$ measured -1$) \times 100 \%$. 


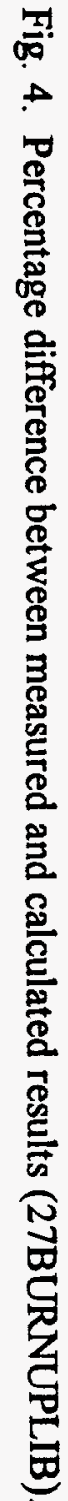

Percent Difference (Calculated/Measured-1)x100\%

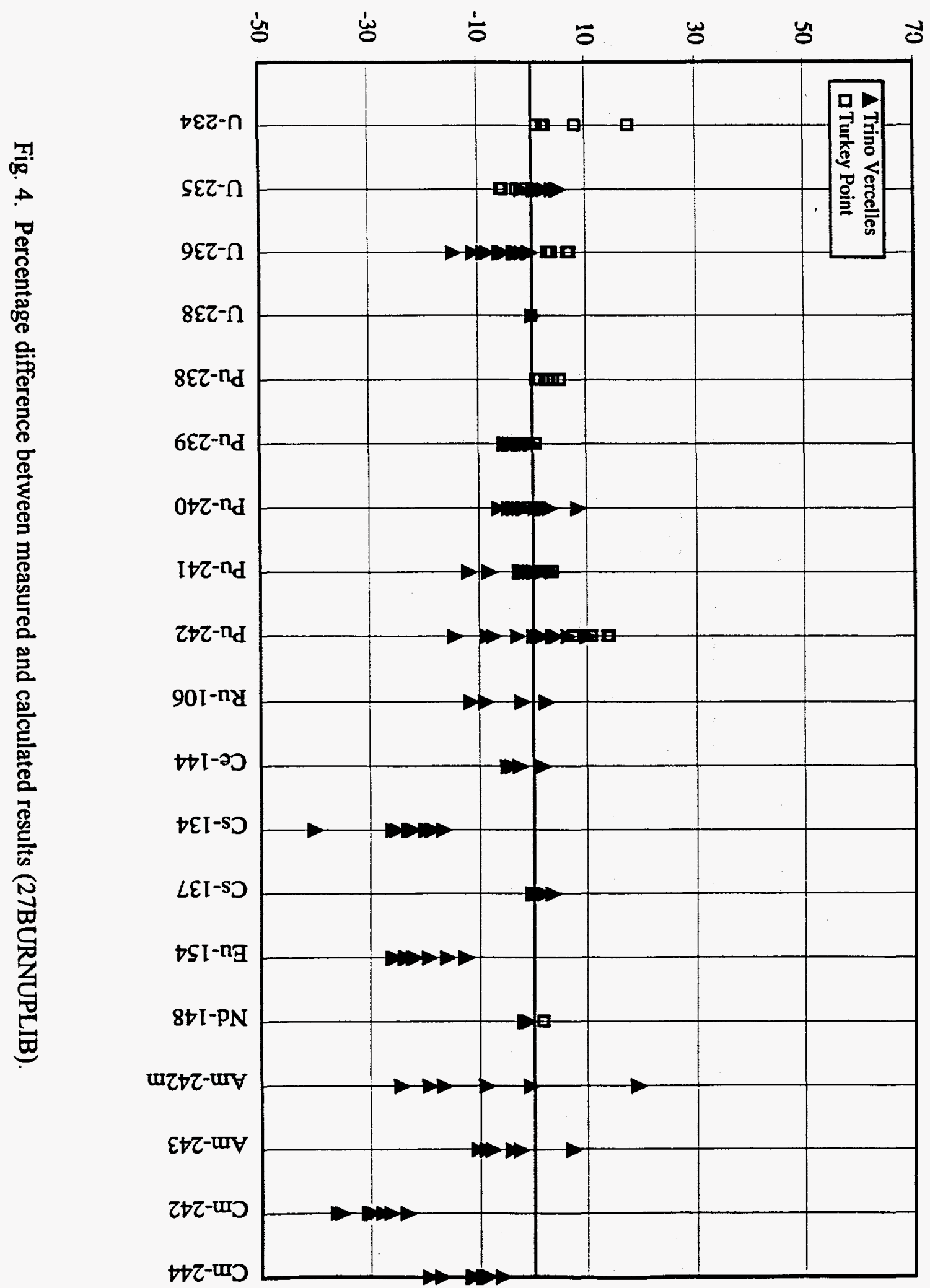




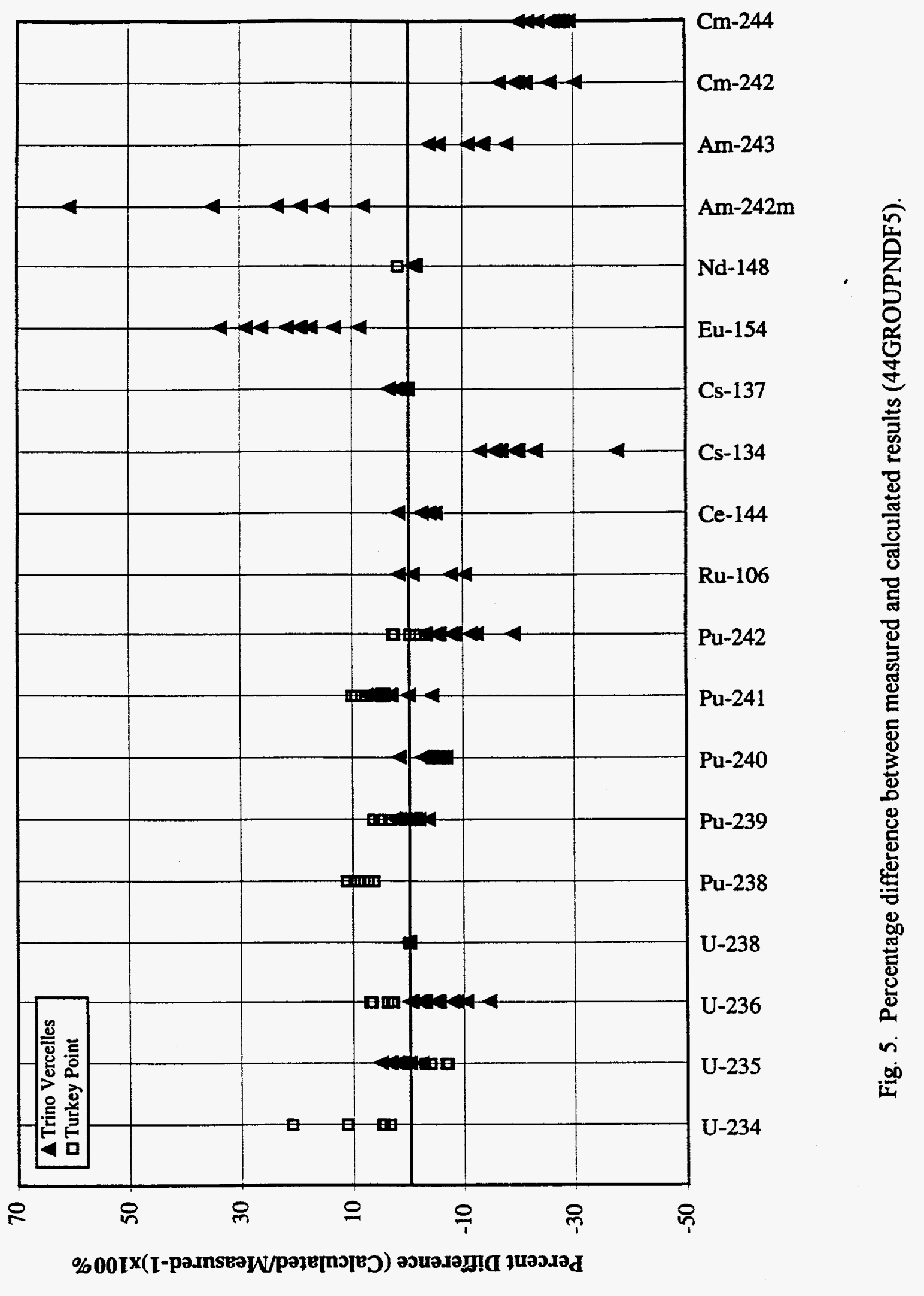


Table 20. Combination of the current and previous validation summaries, listing percentage differences between measured and computed compositions

\begin{tabular}{|c|c|c|c|c|c|c|c|c|}
\hline \multirow[b]{3}{*}{ No. } & \multirow{3}{*}{$\begin{array}{l}\text { Nuclide, } \\
\text { isobar, or sum } \\
\text { of nuclides }\end{array}$} & \multirow{3}{*}{$\begin{array}{l}\text { Total } \\
\text { cases }\end{array}$} & \multicolumn{6}{|c|}{ Average percentage differences ${ }^{a}$} \\
\hline & & & \multicolumn{3}{|c|}{ 27BURNUPLIB data } & \multicolumn{3}{|c|}{ 44GROUPNDF5 data } \\
\hline & & & Current $^{b}$ & Previous ${ }^{\circ}$ & Combined & Current $^{b}$ & Previous ${ }^{\circ}$ & Combined \\
\hline 1 & ${ }^{234} \mathrm{U}$ & 14 & 8.9 & 4.7 & 6.2 & 6.1 & 1.8 & 3.3 \\
\hline 2 & ${ }^{235} \mathrm{U}$ & 38 & -0.3 & -2.9 & -1.6 & 0.1 & -1.9 & -0.9 \\
\hline 3 & ${ }^{236} \mathrm{U}$ & 38 & -2.6 & 0.7 & -1.0 & -2.8 & 0.6 & -1.1 \\
\hline 4 & ${ }^{238} \mathrm{U}$ & 32 & $<0.1$ & -0.6 & -0.3 & $<0.1$ & -0.6 & -0.3 \\
\hline 5 & ${ }^{238} \mathrm{Pu}$ & 24 & 8.6 & 0.7 & 2.4 & 2.6 & -4.6 & -3.1 \\
\hline 6 & ${ }^{239} \mathrm{Pu}$ & 38 & 1.0 & 5.3 & 3.1 & -2.1 & -0.6 & -1.3 \\
\hline 7 & ${ }^{240} \mathrm{Pu}$ & 38 & -4.4 & -5.8 & -5.1 & -0.2 & -0.3 & -0.2 \\
\hline 8 & ${ }^{241} \mathrm{Pu}$ & 38 & 5.2 & 5.0 & 5.1 & -1.0 & -1.2 & -1.1 \\
\hline 9 & ${ }^{242} \mathrm{Pu}$ & 34 & -6.3 & -10.3 & -8.1 & 3.1 & -0.2 & 1.7 \\
\hline 10 & ${ }^{237} \mathrm{~Np}$ & 13 & - & 19.2 & 19.2 & - & 6.4 & 6.4 \\
\hline 11 & ${ }^{241} \mathrm{Am}$ & 9 & - & -5.9 & -5.9 & - & -11.0 & -11.0 \\
\hline 12 & ${ }^{242 m} \mathrm{Am}$ & 6 & 26.8 & - & 26.8 & -8.5 & - & -8.5 \\
\hline 13 & ${ }^{243} \mathrm{Am}$ & 6 & -11.1 & - & -11.1 & -4.3 & - & -4.3 \\
\hline 14 & ${ }^{242} \mathrm{Cm}$ & 15 & -21.7 & -18.7 & -20.5 & -29.8 & -25.0 & -27.9 \\
\hline 15 & ${ }^{243} \mathrm{Cm}+{ }^{244} \mathrm{Cm}$ & 9 & - & -15.8 & -15.8 & - & -2.3 & -2.3 \\
\hline 16 & ${ }^{244} \mathrm{Cm}$ & 15 & -25.6 & -22.7 & -24.4 & -11.3 & -7.1 & -9.6 \\
\hline 17 & ${ }^{14} \mathrm{C}$ & 3 & - & -14.2 & -14.2 & - & -13.8 & -13.8 \\
\hline 18 & ${ }^{79} \mathrm{Se}$ & 9 & - & 14.1 & 14.1 & - & 14.0 & 14.0 \\
\hline 19 & ${ }^{90} \mathrm{Sr}$ & 9 & - & 6.1 & 6.1 & - & 6.0 & 6.0 \\
\hline 20 & ${ }^{99} \mathrm{Tc}$ & 13 & - & 15.8 & 15.8 & - & 16.3 & 16.3 \\
\hline 21 & ${ }^{106} \mathrm{Ru}$ & 4 & -4.5 & - & -4.5 & -5.0 & - & -5.0 \\
\hline 22 & ${ }^{126} \mathrm{Sn}$ & 6 & - & 230.3 & 230.3 & - & 229.8 & 229.8 \\
\hline 23 & ${ }^{129} \mathrm{I}$ & 3 & - & -10.8 & -10.8 & - & -10.8 & -10.8 \\
\hline 24 & ${ }^{133} \mathrm{Cs}$ & 3 & - & 1.9 & 1.9 & - & 2.5 & 2.5 \\
\hline 25 & ${ }^{134} \mathrm{Cs}$ & 16 & -20.1 & -8.1 & -17.8 & -23.0 & -11.4 & -20.8 \\
\hline
\end{tabular}


Table 20 (continued)

\begin{tabular}{|c|c|c|c|c|c|c|c|c|}
\hline \multirow[b]{3}{*}{ No. } & \multirow{3}{*}{$\begin{array}{l}\text { Nuclide, } \\
\text { isobar, or sum } \\
\text { of nuclides }\end{array}$} & \multirow{3}{*}{$\begin{array}{l}\text { Total } \\
\text { cases }\end{array}$} & \multicolumn{6}{|c|}{ Average percentage differences ${ }^{a}$} \\
\hline & & & \multicolumn{3}{|c|}{ 27BURNUPLIB data } & \multicolumn{3}{|c|}{ 44GROUPNDF5 data } \\
\hline & & & Current $^{b}$ & Previous $^{c}$ & Combined & Current $^{b}$ & Previous $^{c}$ & Combined \\
\hline 26 & ${ }^{135} \mathrm{Cs}$ & 9 & - & 10.9 & 10.9 & - & 5.7 & 5.7 \\
\hline 27 & ${ }^{137} \mathrm{Cs}$ & 26 & 1.4 & 0.9 & 1.1 & 1.3 & 0.8 & 1.1 \\
\hline 28 & ${ }^{144} \mathrm{Ce}$ & 4 & -2.5 & - & -2.5 & -2.4 & - & -2.4 \\
\hline 29 & ${ }^{143} \mathrm{Nd}$ & 3 & - & 1.3 & 1.3 & - & 0.4 & 0.4 \\
\hline 30 & ${ }^{144} \mathrm{Nd}$ & 3 & - & 0.1 & 0.1 & - & 0.5 & 0.5 \\
\hline 31 & ${ }^{145} \mathrm{Nd}$ & 3 & - & 0.4 & 0.4 & - & -0.3 & -0.3 \\
\hline 32 & ${ }^{146} \mathrm{Nd}$ & 3 & - & 0.4 & 0.4 & - & 1.1 & 1.1 \\
\hline 33 & ${ }^{148} \mathrm{Nd}$ & 16 & -0.3 & 0.3 & -0.2 & -0.2 & 0.4 & -0.1 \\
\hline 34 & ${ }^{150} \mathrm{Nd}$ & 3 & - & 3.2 & 3.2 & - & 3.4 & 3.4 \\
\hline 35 & ${ }^{147} \mathrm{Pm} . .{ }^{147} \mathrm{Sm}$ & 3 & - & -4.5 & -4.5 & - & -2.8 & -2.8 \\
\hline 36 & ${ }^{148} \mathrm{Sm}$ & 3 & - & -15.9 & -15.9 & - & -16.9 & -16.9 \\
\hline 37 & ${ }^{149} \mathrm{Sm}$ & 3 & - & -30.3 & -30.3 & - & -35.9 & -35.9 \\
\hline 38 & ${ }^{150} \mathrm{Sm}$ & 3 & - & -0.5 & -0.5 & - & -1.5 & -1.5 \\
\hline 39 & ${ }^{151} \mathrm{Sm} . .{ }^{151} \mathrm{Eu}$ & 3 & - & 26.1 & 26.1 & - & 28.1 & 28.1 \\
\hline 40 & ${ }^{152} \mathrm{Sm}$ & 3 & - & 17.3 & 17.3 & - & 20.2 & 20.2 \\
\hline 41 & ${ }^{153} \mathrm{Eu}$ & 3 & - & -4.8 & -4.8 & - & 5.0 & 5.0 \\
\hline 42 & ${ }^{154} \mathrm{Eu}$ & 9 & 20.9 & - & 20.9 & -21.3 & - & -21.3 \\
\hline 43 & ${ }^{154} \mathrm{Eu} . . .{ }^{154} \mathrm{Gd}$ & 3 & - & 30.8 & 30.8 & - & -2.1 & -2.1 \\
\hline 44 & ${ }^{155} \mathrm{Eu} . . .{ }^{155} \mathrm{Gd}$ & 3 & - & 96.0 & 96.0 & - & -24.4 & -24.4 \\
\hline
\end{tabular}

${ }^{a}$ (Calculated/measured - 1) $\times 100 \%$.

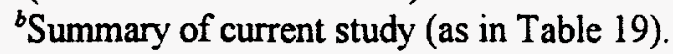

'Summary of previous study, in ref. 9. 


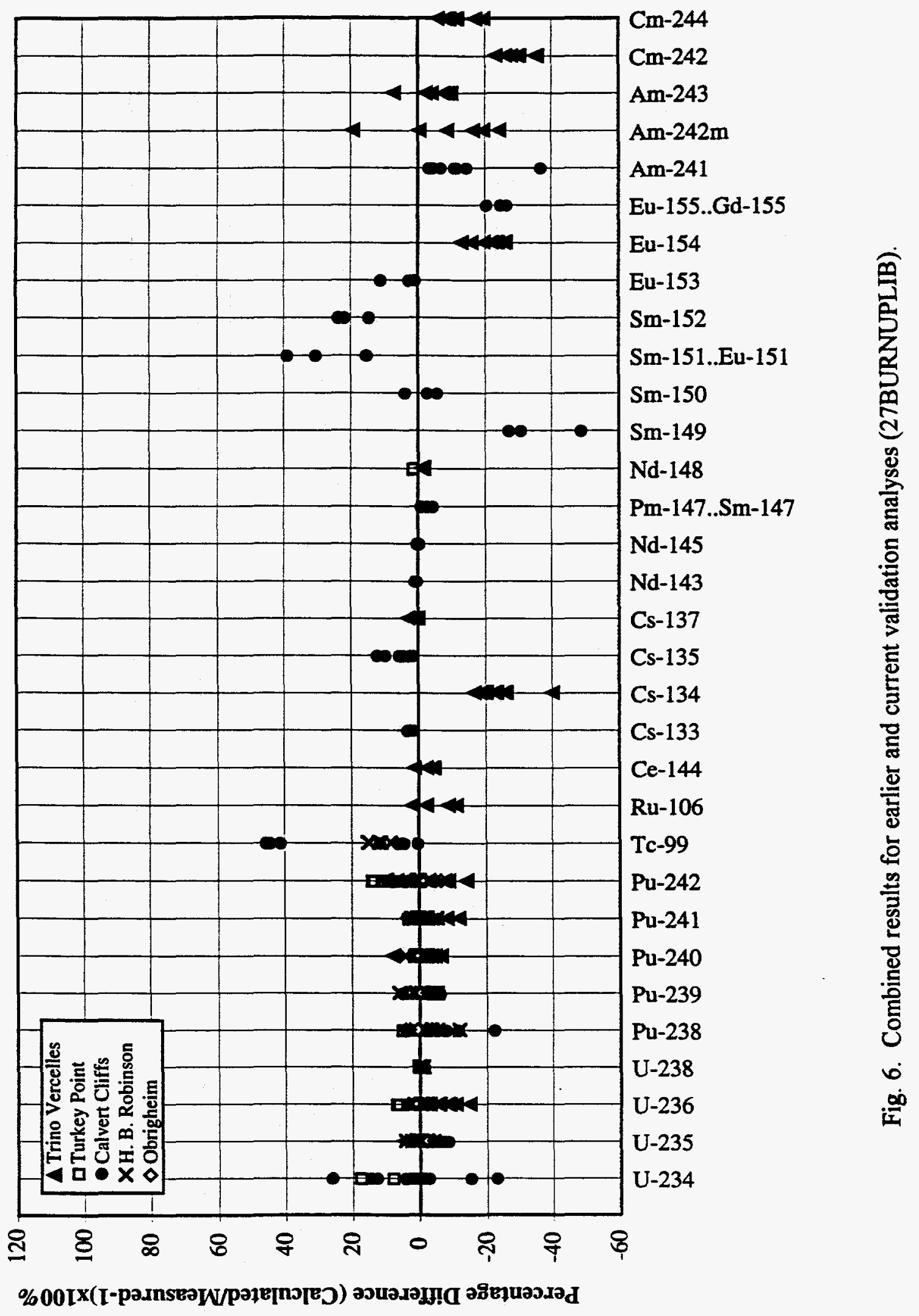




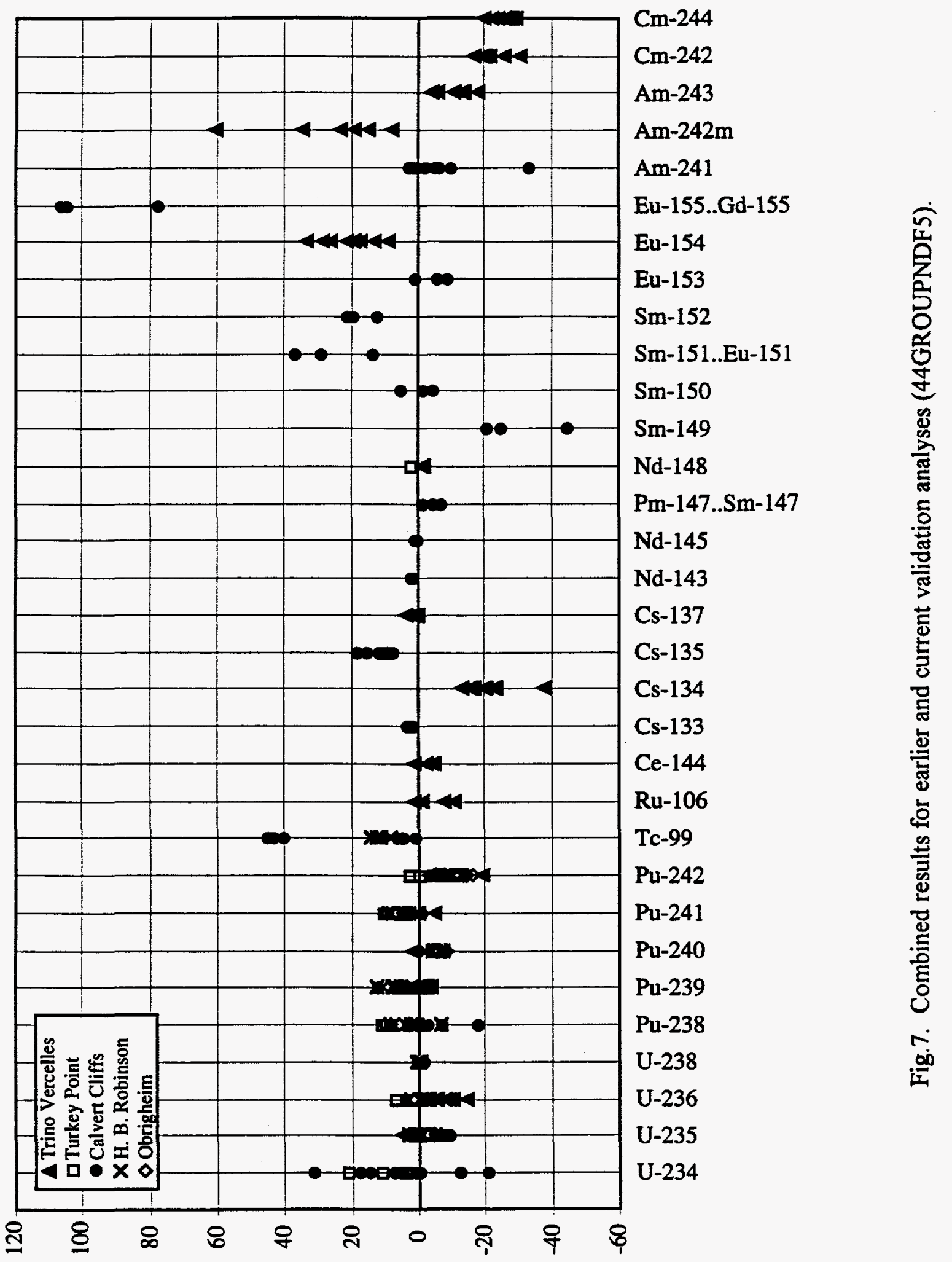

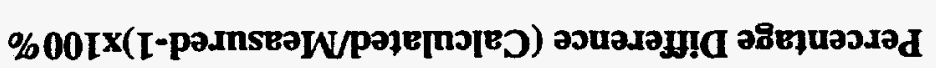




\section{STATISTICAL COMBINATION OF MEASURED-TO-COMPUTED ISOTOPIC RATIOS}

Differences between calculated and measured isotopic concentrations for any given fuel sample result from biases and uncertainties in both the calculational method and in the original experimental measurement. Isotopic uncertainty is a consequence of the variation of physical parameters in a random fashion relative to modeled parameters, combined with the random error associated with experimental measurements. Isotopic bias, on the other hand, is the offset between the measured nuclide concentration for a given nuclide and the corresponding calculational prediction of the concentration of that nuclide after accounting for uncertainties. Isotopic bias can result from both the method used in experimental measurements and from the assumptions, data, and method used in computational prediction of nuclide densities.

Reference 3 describes a statistical approach in which the bias and uncertainty terms associated with the prediction of the concentration of a given isotope are estimated from a set of measured-to-calculated ratios. Although the details of this statistical approach are provided in ref. 3 , the key aspects are summarized here to provide a basic understanding of the computed parameters provided later in this section.

In this statistical approach, calculational bias is represented by the term $\bar{x}$, which is defined as the average measured $(\mathrm{M})$ to calculated $(\mathrm{C})$ ratio for a number of comparisons ( $\mathrm{n}$ ) made for a given isotope [i.e., $\left.\bar{x}=(1 \mathrm{~m}) \sum_{i} M_{i} / C_{i}\right]$. Thus, based on a sufficient number of measured-to-calculated ratios, the "expected" isotopic concentration, $e$, that would be experimentally measured for an additional fuel sample may be estimated from a calculated concentration for that sample, $\mathrm{C}$, by the relationship $e=\mathrm{C} \cdot \overline{\mathrm{x}}$. This is a bestestimate approach for predicting actual spent fuel contents; however, this does not account for the effect of the uncertainty associated with $\bar{x}$. The upper and lower bounds on $e, \epsilon^{ \pm}$, are defined as $\epsilon^{ \pm}=C \cdot(\bar{x} \pm T \cdot s)$, where $s$ is the standard deviation associated with $\bar{x}$, and $T$ is a tolerance factor selected for a desired confidence level; the definition and significance of these terms are provided in ref. 3 . The term $(\bar{x} \pm T \cdot s)$ is a bounding correction factor for $\mathrm{C}$ and is often referred to simply as $f$.

In a criticality calculation, conservatism would require selecting an upper bound for estimates of productive $\left(v \sigma_{\mathrm{f}} / \sigma_{\mathrm{a}}>1\right)$ isotopes (also called fissile isotopes) and a lower bound for nonproductive $\left(v \sigma_{\mathrm{f}} / \sigma_{\mathrm{a}}\right.$ $<1$ ), or absorber, nuclides. Thus there are two definitions of $f$, depending on whether it is calculated for a fissile or absorber nuclide: $f_{\text {fissile }}=\bar{x}+T \cdot s$, and $f_{\text {absorber }}=\bar{x}-T \cdot s$.

Additional conservatism can be included in this approach by prohibiting compensating effects. (Compensating effects can occur when the correction of one nuclide results in a positive increase in system 
reactivity, while the correction of another nuclide results in a negative offsetting change in reactivity. Hence the negative contribution compensates for the positive effect.) It is mathematically possible that the most conservative correction factor for a given isotope will result in a value of $\epsilon$ that is less conservative (in a relative sense) than the calculated concentration. In other words, for a fissile material, if $f_{\text {tissile }}<1$, then $\in$ will be less than $C$, and $C$ represents the more conservative value (because $C$ would result in increased neutron production). Conversely, for absorber isotopes, $f_{\text {absorber }}>1$ means that $\epsilon$ will be greater than $\mathrm{C}$, and again $\mathrm{C}$ represents the more conservative value (in this case, $C$ would result in less neutron absorption). Thus to disallow compensating effects, a modified correction factor, $f^{\prime}$, is defined as $f_{\text {fissile }}^{\prime}=\max [(\overline{\mathrm{x}}+\mathrm{T} \cdot \mathrm{s}), 1]$ for fissile isotopes, and $f_{\text {absorber }}^{\prime}=\min [(\overline{\mathrm{x}}-\mathrm{T} \cdot \mathrm{s}), 1]$ for absorber isotopes. The modified correction factor, $f^{\prime}$, has been developed specifically for the needs of burnup credit applications. ${ }^{3}$

Based on the measured and computed nuclides provided in Appendices D and E for Trino Vercelles and Turkey Point Unit 3 fuel samples, respectively, and those provided in ref. 9 for 19 other fuel samples, Table 21 provides the values of $n$ (number of independent fuel samples), $\bar{x}, \mathrm{~s}, \mathrm{~T}, f$, and $f^{\prime}$ for each of the isotopes for which both calculated and measured values are available; calculated values were obtained using the SCALE 27-group cross-section library. Table 22 lists the same parameters with calculated values obtained using the more recently developed SCALE 44-group cross-section library. Note that in both tables $T$ is a tabulated value determined as a function of $n$ for a $95 \% / 95 \%$ confidence level. The value of $n$ ranges from as few as 3 samples to as many as 38 spent fuel samples. The value of $f$ calculated based on the earlier subset of measurements (for a more limited set of nuclides) is given in the final column of each table. Note that because no additional measurements were included for most fission products in the current work, $f$ remains unchanged for these nuclides. However, for nuclides for which additional measurements were available, $f$ is seen to improve, for the most part. (Improvement is determined as a revised $f$ value that is closer to 1.0 than the earlier value.) 
Table 21. Best-estimate and conservative correction factors for 27BURNUPBLIB results

\begin{tabular}{|c|c|c|c|c|c|c|c|}
\hline Isotope & $n$ & $\overline{\bar{x}}$ & $s$ & $\mathrm{~T}_{95 / 95}$ & $f$ & $f^{\prime}$ & $f$ (earlier work) \\
\hline${ }^{14} \mathrm{C}$ & $3^{b}$ & 1.1726 & 0.109 & 7.656 & 0.338 & 0.338 & \\
\hline${ }^{79} \mathrm{Se}$ & $9^{b}$ & 0.8842 & 0.087 & 3.031 & 0.621 & 0.621 & \\
\hline${ }^{90} \mathrm{Sr}$ & $9^{b}$ & 0.9422 & 0.011 & 3.031 & 0.909 & 0.909 & \\
\hline${ }^{99} \mathrm{Tc}$ & $13^{b}$ & 0.8767 & 0.106 & 2.671 & 0.594 & 0.594 & 0.594 \\
\hline${ }^{106} \mathrm{Ru}$ & $4^{c}$ & 1.0494 & 0.062 & 5.144 & 0.730 & 0.730 & \\
\hline${ }^{126} \mathrm{Sn}$ & $6^{b}$ & 0.3085 & 0.046 & 3.708 & 0.138 & 0.138 & \\
\hline${ }^{129} \mathrm{I}$ & $3^{b}$ & 1.1230 & 0.055 & 7.656 & 0.702 & 0.702 & \\
\hline${ }^{133} \mathrm{Cs}$ & $3^{6}$ & 0.9814 & 0.007 & 7.656 & 0.928 & 0.928 & 0.928 \\
\hline${ }^{134} \mathrm{Cs}$ & 16 & 1.2285 & 0.128 & 2.524 & 0.905 & 0.905 & \\
\hline${ }^{135} \mathrm{Cs}$ & $9^{b}$ & 0.9022 & 0.027 & 3.031 & 0.820 & 0.820 & 0.820 \\
\hline${ }^{137} \mathrm{Cs}$ & 26 & 0.9892 & 0.014 & 2.275 & 0.957 & 0.957 & \\
\hline${ }^{144} \mathrm{Ce}$ & $4^{c}$ & 1.0264 & 0.029 & 5.144 & 0.877 & 0.877 & \\
\hline${ }^{143} \mathrm{Nd}$ & $3^{b}$ & 0.9909 & 0.008 & 7.656 & 0.930 . & 0.930 & 0.930 \\
\hline${ }^{144} \mathrm{Nd}$ & $3^{b}$ & 1.0034 & 0.006 & 7.656 & 0.957 & 0.957 & \\
\hline${ }^{145} \mathrm{Nd}$ & $3^{b}$ & 0.9961 & 0.002 & 7.656 & 0.981 & 0.981 & 0.981 \\
\hline${ }^{146} \mathrm{Nd}$ & $3^{b}$ & 0.9993 & 0.006 & 7.656 & 0.953 & 0.953 & \\
\hline${ }^{148} \mathrm{Nd}$ & 16 & 0.9997 & 0.018 & 2.524 & 0.954 & 0.954 & \\
\hline${ }^{150} \mathrm{Nd}$ & $3^{b}$ & 0.9549 & 0.017 & 7.656 & 0.825 & 0.825 & \\
\hline${ }^{147} \mathrm{Pm} . .{ }^{147} \mathrm{Sm}$ & $3^{b}$ & 1.0346 & 0.047 & 7.656 & 0.675 & 0.675 & 0.675 \\
\hline${ }^{148} \mathrm{Sm}$ & $3^{b}$ & 1.1755 & 0.031 & 7.656 & 0.938 & 0.938 & \\
\hline${ }^{149} \mathrm{Sm}$ & $3^{b}$ & 1.3892 & 0.378 & 7.656 & $0.000^{d}$ & $0.000^{d}$ & 0.000 \\
\hline${ }^{150} \mathrm{Sm}$ & $3^{b}$ & 0.9923 & 0.048 & 7.656 & 0.625 & 0.625 & 0.625 \\
\hline${ }^{152} \mathrm{Sm}$ & $3^{b}$ & 0.8361 & 0.008 & 7.656 & 0.775 & 0.775 & 0.775 \\
\hline${ }^{151} \mathrm{Sm} . .{ }^{151} \mathrm{Eu}$ & $3^{b}$ & 0.7703 & 0.036 & 7.656 & 0.495 & 0.495 & 0.495 \\
\hline${ }^{153} \mathrm{Eu}$ & $3^{b}$ & 1.0369 & 0.057 & 7.656 & 0.601 & 0.601 & 0.601 \\
\hline${ }^{154} \mathrm{Eu}$ & $9^{c}$ & 0.8301 & 0.053 & 3.031 & 0.669 & 0.669 & \\
\hline${ }^{154} \mathrm{Sm} . .{ }^{154} \mathrm{Gd}$ & $3^{b}$ & 0.7603 & 0.041 & 7.656 & 0.446 & 0.446 & \\
\hline${ }^{155} \mathrm{Eu} . . .{ }^{155} \mathrm{Gd}$ & $3^{b}$ & 0.5272 & 0.069 & 7.656 & $0.000^{d}$ & $0.000^{d}$ & 0.000 \\
\hline $234 \mathrm{U}$ & 14 & 0.9564 & 0.128 & 2.614 & 0.622 & 0.622 & 0.509 \\
\hline${ }^{235} \mathrm{U}^{a}$ & 38 & 1.0175 & 0.039 & 2.141 & 1.101 & 1.101 & 1.115 \\
\hline $236 \mathrm{U}$ & 38 & 1.0119 & 0.048 & 2.141 & 0.909 & 0.909 & 0.955 \\
\hline${ }^{238} \mathrm{U}$ & 32 & 1.0027 & 0.005 & 2.197 & 0.992 & 0.992 & 0.990 \\
\hline${ }^{237} \mathrm{~Np}$ & $13^{6}$ & 0.8467 & 0.084 & 2.671 & 0.622 & 0.622 & \\
\hline${ }^{238} \mathrm{Pu}$ & 24 & 0.9780 & 0.071 & 2.309 & 0.814 & 0.814 & 0.830 \\
\hline${ }^{239} \mathrm{Pu}^{a}$ & 38 & 0.9708 & 0.036 & 2.141 & 1.048 & 1.048 & 1.033 \\
\hline${ }^{240} \mathrm{Pu}$ & 38 & 1.0536 & 0.021 & 2.141 & 1.009 & 1.000 & 1.013 \\
\hline${ }^{241} \mathrm{Pu}^{a}$ & 38 & 0.9522 & 0.029 & 2.141 & 1.014 & 1.014 & 1.016 \\
\hline${ }^{242} \mathrm{Pu}$ & 34 & 1.0908 & 0.059 & 2.176 & 0.962 & 0.962 & 1.006 \\
\hline${ }^{241} \mathrm{Am}$ & $9^{b}$ & 1.0800 & 0.164 & 3.031 & 0.583 & 0.583 & 0.583 \\
\hline${ }^{242 \mathrm{~m}} \mathrm{Am}$ & $6^{c}$ & 0.8016 & 0.107 & 3.708 & 0.405 & 0.405 & \\
\hline${ }^{243} \mathrm{Am}$ & $6^{c}$ & 1.1279 & 0.066 & 3.708 & 0.883 & 0.883 & \\
\hline${ }^{242} \mathrm{Cm}$ & 15 & 1.2609 & 0.068 & 2.566 & 1.086 & 1.000 & \\
\hline${ }^{243} \mathrm{Cm}+{ }^{244} \mathrm{Cm}$ & $9^{b}$ & 1.1934 & 0.094 & 3.031 & 0.908 & 0.908 & \\
\hline${ }^{244} \mathrm{Cm}$ & 15 & 1.3250 & 0.052 & 2.566 & 1.192 & 1.000 & \\
\hline
\end{tabular}

${ }^{a}$ Fissile isotope.

${ }^{b}$ Based on measurements reported in ref. 9 only; not measured in current work.

'Based on measurements reported herein; not included in ref. 9.

$d$ Factors less than zero are set to zero, as negative concentrations are meaningless.

'From ref. 8. 
Table 22. Best-estimate and conservative correction factors for 44GROUPNDF5 results

\begin{tabular}{|c|c|c|c|c|c|c|c|}
\hline Isotope & $n$ & $\overline{\bar{x}}$ & s & $\mathrm{T}_{95 / 95}$ & $f$ & $f^{\prime}$ & $f($ earlier work) \\
\hline${ }^{14} \mathrm{C}$ & $3^{b}$ & 1.1677 & 0.108 & 7.656 & 0.341 & 0.341 & \\
\hline${ }^{79} \mathrm{Se}$ & $9^{b}$ & 0.8850 & 0.087 & 3.031 & 0.621 & 0.621 & \\
\hline${ }^{90} \mathrm{Sr}$ & $9^{b}$ & 0.9432 & 0.011 & 3.031 & 0.910 & 0.910 & \\
\hline${ }^{99} \mathrm{Tc}$ & $13^{b}$ & 0.8732 & 0.106 & 2.671 & 0.590 & 0.590 & 0.590 \\
\hline${ }^{106} \mathrm{Ru}$ & $4^{e}$ & 1.0563 & 0.070 & 5.144 & 0.696 & 0.696 & \\
\hline${ }^{126} \mathrm{Sn}$ & $6^{b}$ & 0.3088 & 0.045 & 3.708 & 0.142 & 0.142 & \\
\hline${ }^{129} \mathrm{I}$ & $3^{b}$ & 1.1224 & 0.055 & 7.656 & 0.701 & 0.701 & \\
\hline${ }^{133} \mathrm{Cs}$ & $3^{b}$ & 0.9759 & 0.009 & 7.656 & 0.907 & 0.907 & 0.910 \\
\hline${ }^{134} \mathrm{Cs}$ & 16 & 1.2752 & 0.133 & 2.524 & 0.940 & 0.940 & \\
\hline${ }^{135} \mathrm{Cs}$ & $9^{b}$ & 0.9471 & 0.029 & 3.031 & 0.859 & 0.859 & 0.859 \\
\hline${ }^{137} \mathrm{Cs}$ & 26 & 0.9894 & 0.014 & 2.275 & 0.958 & 0.958 & \\
\hline${ }^{144} \mathrm{Ce}$ & $4^{c}$ & 1.0256 & 0.030 & 5.144 & 0.871 & 0.871 & \\
\hline${ }^{143} \mathrm{Nd}$ & $3^{b}$ & 1.0000 & 0.005 & 7.656 & 0.962 & 0.962 & 0.962 \\
\hline${ }^{144} \mathrm{Nd}$ & $3^{b}$ & 0.9993 & 0.007 & 7.656 & 0.946 & 0.946 & \\
\hline${ }^{145} \mathrm{Nd}$ & $3^{b}$ & 1.0032 & 0.004 & 7.656 & 0.973 & 0.973 & 0.973 \\
\hline${ }^{146} \mathrm{Nd}$ & $3^{b}$ & 0.9925 & 0.007 & 7.656 & 0.939 & 0.939 & \\
\hline${ }^{148} \mathrm{Nd}$ & 16 & 0.9992 & 0.018 & 2.524 & 0.954 & 0.954 & \\
\hline${ }^{150} \mathrm{Nd}$ & $3^{b}$ & 0.9535 & 0.017 & 7.656 & 0.823 & 0.823 & \\
\hline${ }^{147} \mathrm{Pm} . .{ }^{147} \mathrm{Sm}$ & $3^{b}$ & 1.0170 & 0.042 & 7.656 & 0.695 & 0.695 & \\
\hline${ }^{148} \mathrm{Sm}$ & $3^{b}$ & 1.1891 & 0.029 & 7.656 & 0.967 & 0.967 & \\
\hline${ }^{149} \mathrm{Sm}$ & $3^{b}$ & 1.5095 & 0.406 & 7.656 & $0.000^{d}$ & $0.000^{d}$ & 0.000 \\
\hline${ }^{150} \mathrm{Sm}$ & $3^{b}$ & 1.0018 & 0.050 & 7.656 & 0.619 & 0.619 & 0.619 \\
\hline${ }^{152} \mathrm{Sm}$ & $3^{b}$ & 0.8162 & 0.008 & 7.656 & 0.755 & 0.755 & 0.755 \\
\hline${ }^{151} \mathrm{Sm} .{ }^{151} \mathrm{Eu}$ & $3^{b}$ & 0.7584 & 0.033 & 7.656 & 0.506 & 0.506 & 0.506 \\
\hline${ }^{153} \mathrm{Eu}$ & $3^{b}$ & 0.9395 & 0.039 & 7.656 & 0.641 & 0.641 & 0.641 \\
\hline${ }^{154} \mathrm{Eu}$ & $9^{c}$ & 1.2735 & 0.070 & 3.031 & 1.061 & 1.000 & \\
\hline${ }^{154} \mathrm{Sm} \ldots{ }^{154} \mathrm{Gd}$ & $3^{b}$ & 1.0144 & 0.035 & 7.656 & 0.746 & 0.746 & \\
\hline${ }^{155} \mathrm{Eu} . . .{ }^{155} \mathrm{Gd}$ & $3^{b}$ & 1.3586 & 0.109 & 7.656 & 0.524 & 0.524 & 0.524 \\
\hline${ }^{234} \mathrm{U}$ & 14 & 0.9829 & 0.133 & 2.614 & 0.635 & 0.635 & 0.519 \\
\hline${ }^{235} \mathrm{U}^{a}$ & 38 & 1.0104 & 0.035 & 2.141 & 1.085 & 1.085 & 1.104 \\
\hline${ }^{236} \mathrm{U}$ & 38 & 1.0132 & 0.048 & 2.141 & 0.910 & 0.910 & 0.956 \\
\hline${ }^{238} \mathrm{U}$ & 32 & 1.0026 & 0.005 & 2.197 & 0.992 & 0.992 & 0.991 \\
\hline${ }^{237} \mathrm{~Np}$ & $13^{b}$ & 0.9484 & 0.094 & 2.671 & 0.697 & 0.697 & \\
\hline${ }^{238} \mathrm{Pu}$ & 24 & 1.0338 & 0.077 & 2.309 & 0.856 & 0.856 & 0.871 \\
\hline${ }^{239} \mathrm{Pu}^{a}$ & 38 & 1.0142 & 0.029 & 2.141 & 1.076 & 1.076 & 1.092 \\
\hline${ }^{240} \mathrm{Pu}$ & 38 & 1.0030 & 0.027 & 2.141 & 0.945 & 0.945 & 0.957 \\
\hline${ }^{241} \mathrm{Pu}^{a}$ & 38 & 1.0119 & 0.035 & 2.141 & 1.087 & 1.087 & 1.080 \\
\hline${ }^{242} \mathrm{Pu}$ & 34 & 0.9875 & 0.064 & 2.176 & 0.848 & 0.848 & 0.911 \\
\hline${ }^{241} \mathrm{Am}$ & $9^{b}$ & 1.1420 & 0.176 & 3.031 & 0.609 & 0.609 & 0.609 \\
\hline${ }^{242 \mathrm{~m}} \mathrm{Am}$ & $6^{c}$ & 1.1181 & 0.177 & 3.708 & 0.462 & 0.462 & \\
\hline${ }^{243} \mathrm{Am}$ & $6^{c}$ & 1.0491 & 0.066 & 3.708 & 0.804 & 0.804 & \\
\hline${ }^{242} \mathrm{Cm}$ & 15 & 1.3916 & 0.087 & 2.566 & 1.168 & 1.000 & \\
\hline${ }^{243} \mathrm{Cm}+{ }^{244} \mathrm{Cm}$ & $9^{b}$ & 1.0266 & 0.063 & 3.031 & 0.836 & 0.836 & \\
\hline${ }^{244} \mathrm{Cm}$ & 15 & 1.1090 & 0.053 & 2.566 & 0.973 & 0.973 & \\
\hline
\end{tabular}

Fissile isotope.

Based on measurements reported in ref. 9 only; not measured in current work.

Based on measurements reported herein; not included in ref. 9.

Factors less than zero are set to zero. as negative concentrations are meaningless.

From ref. 8. 


\section{SUMMARY}

Knowledge of the isotopic composition of spent commercial LWR fuel is important in many aspects of transportation and storage of the fuel. Because it is not feasible to destructively assay every spent fuel element removed from a reactor, it is necessary to use computational methods to estimate spent fuel contents. The ultimate goal is to provide an adequate prediction of isotopic contents of PWR spent fuel assemblies based solely on calculational methods and to provide an estimate of the uncertainty in that prediction. Thus it is necessary to perform validation studies to assess the accuracy of a computational method relative to reality, where reality is gauged by experimental measurements.

The results presented in Sect. 3 of this report demonstrate the accuracy of the SAS2H sequence in SCALE-4.2 for prediction of isotopic concentrations. As illustrated in Table 20, in comparing the current and the earlier work, no major differences in the ability to predict specific nuclide concentrations are noted. In other words, those nuclides which were predicted within a few percent in the earlier work were predicted within a few percent in the current work, and isotopes for which errors were greater than a few percent in the earlier work were found to be in error by comparable amounts in the current work. This consistency was observed for results obtained from each of the two different cross-section libraries that have been used in the validation studies. This consistency suggests that the estimated biases determined for each of the isotopes in the earlier work are reasonably good estimates, as the additional measurement/calculated ratios resulting from the current work tend to confirm these estimates. The fact that the more recent results are taken from different reactor types and facilities and were based on measurements performed by different organizations than those of the earlier work indicates that the biases are largely independent of other factors or modeling.

In general, the prediction of nuclide inventories for uranium isotopes is within about $1 \%$, with the exception of ${ }^{234} \mathrm{U}$, which is generally predicted in the range of 2 to $6 \%$ (this relatively broad variation may result from the correlation used to estimate the initial loading of this isotope, since these data are not generally directly provided in available references). Predictions for plutonium isotopic concentrations vary by isotope. Plutonium-238 and -242 show the largest variation between measurements; hence these isotopes show the most significant variation between earlier and current 
averages. This may be due in part to the small amount of each nuclide present in spent fuel relative to the other plutonium nuclides. Plutonium-239, -240 , and -241 are predicted on the order of about $5 \%$ using the 27 -group library, and within 1 to $2 \%$ based on calculations using the 44-group library. Much of the improvement in plutonium prediction for these nuclides using the 44-group library may result from the fact that the group structure for this cross-section library was specifically tailored to capture the $0.3-\mathrm{eV}$ resonance in ${ }^{239} \mathrm{Pu}$ (which, due to low energy and lack of resonance data, cannot be properly modeled via the SCALE Nordheim Integral Treatment module NITAWL-II). This improved cross-section representation not only improves the prediction of ${ }^{239} \mathrm{Pu}$ depletion, but also the production of ${ }^{240} \mathrm{Pu}$ and ${ }^{241} \mathrm{Pu}$, which are daughter products by absorption.

This study has provided calculation-to-measurement comparisons for a number of important actinides not included in earlier work. Specifically, data are available in the current work for ${ }^{242 m} \mathrm{Am}$ and ${ }^{243} \mathrm{Am}$, both daughter products of plutonium isotopes by beta decay, and additional measurements for ${ }^{244} \mathrm{Cm}$ are included. The majority of earlier measurements of ${ }^{244} \mathrm{Cm}$ also contained ${ }^{243} \mathrm{Cm}$; the current work contains nine new measurements of ${ }^{244} \mathrm{Cm}$ only. Unfortunately, little measurement data are available for fission-product nuclides so that the range of validation data for most fission products is unchanged in this work; however, additional data were included for ${ }^{134} \mathrm{Cs}$, ${ }^{137} \mathrm{Cs}$, and ${ }^{148} \mathrm{Nd}$, and data for three new fission products, ${ }^{106} \mathrm{Ru},{ }^{144} \mathrm{Ce}$, and ${ }^{154} \mathrm{Eu}$, were introduced.

Section 4 of this report provided the means by which spent fuel nuclide concentrations calculated using SCALE-4.2/SAS2H and either of the two cross-section libraries (27BURNUPLIB or 44GROUPNDF5) could be converted to a best-estimate prediction for actual spent fuel contents or a conservative representation of the spent fuel isotopic concentration. The latter is conservative in terms of a subsequent criticality analysis (i.e., use of conservative correction factors would result in an upper limit in the multiplication factor computed based on spent fuel contents). Use of bestestimate isotopics (i.e., isotopics corrected via multiplication by $\bar{x}$ ) should provide a more realistic estimate for the reactivity of a given spent fuel system; however, it must be recognized that (1) nuclides for which no measurement data exist cannot be validated and are of unknown error, and (2) omission of such nuclides would result in a conservative estimate in total neutron multiplication as these nuclides are neutron absorbers and act to reduce the reactivity worth of the system.

Much work remains in the arena of validation for spent fuel isotopic prediction methods. Although the primary actinides are considered to be well characterized by the up to 38 comparisons 
performed, trending analysis as a function of burnup, initial enrichment, and cooling time have not been performed rigorously; such trending analysis may highlight functional dependencies in the data. In addition, large uncertainties are associated with the prediction of fission-product inventories. Calculation of fission-product concentrations have greater uncertainties due to larger uncertainties in fission-product cross-section data. Thus it is imperative that many more measurements of fission-product nuclides be performed for spent fuel samples in order to validate computational methods and data for estimating fission-product contents in spent fuel. 


\section{REFERENCES}

1. SCALE: A Modular Code System for Performing Standardized Computer Analyses for Licensing Evalwation, NUREG/CR-0200, Rev. 4 (ORNL/NUREG/CSD-2/R4), Vols. I, II, and III (April 1995). Available from Radiation Shielding Information Center, Oak Ridge National Laboratory, as CCC-545.

2. T. L. Sanders and R. M. Westfall, "Feasibility and Incentives for Burnup Credit in Spent Fuel Transport Casks," Nucl. Sci. Eng. 10466 (1990).

3. M. D. DeHart, Sensitivity and Parametric Evaluations of Significam Aspects of Burmup Credit for PWR Spent Fuel Packages, ORNL/TM-12973, Lockheed Martin Energy Research Corp., Oak Ridge Natl. Lab., 1996.

4. M. C. Brady, T. L. Sanders, K. D. Seager, and W. H. Lake, "Burnup Credit Issues in Transportation and Storage, Proc. Tenth International Symposium on the Packaging and Transportation of Radioactive Materials, September 13-18, 1992, Yokohama City, Japan.

5. S. M. Bowman, M. D. DeHart, and C. V. Parks, "Validation of SCALE-4 for Burnup Credit Applications," Nucl. Tech. 11053 (April 1995).

6. M. D. DeHart and C. V. Parks, "Issues Related to Criticality Safety Analysis for Burnup Credit," ICNC '95 Fifth International Conference on Nuclear Criticality Safety, Albuquerque, N.M., September 17-21, 1995, Vol. 1, pp. 1B·26-36 (1995).

7. "American National Standard for Nuclear Criticality Safety in Operations with Fissionable Materials Outside Reactors," ANSU/ANS-8.1-1983, American Nuclear Society, 1983.

8. M. D. DeHart, O. W. Hermann, and C. V. Parks, "Validation of a Method for Prediction of Isotopic Concentrations in Burnup Credit Applications," Fifth International Conference on Nuclear Criticality Safety, Albuquerque, N.M., September 17-21, 1995, Vol. 1, pp. 5·26-34 (1995).

9. O. W. Hermann, S. M. Bowman, M. C. Brady, and C. V. Parks, Validation of the SCALE System for PWR Spent Fuel Isotopic Composition Analyses, ORNL/TM-12667, Martin Marietta Energy Systems, Inc., Oak Ridge Natl. Lab., 1995.

10. O. W. Hermann and C. V. Parks, "SAS2H: The SCALE-4 Analysis Sequence for LWR Fuel Depletion," Proc. Seminar on SCALE-4 and Related Modular Systems for the Evaluation of Nuclear Fuel Facilities and Package Design Featuring Criticality, Shielding, and Heat Transfer Capabilities, September 17-19, 1991, OECD NEA Data Bank, Saclay, 1995. 
11. O. W. Hermann and R. M. Westfall, "ORIGEN-S: SCALE System Module to Calculate Fuel Depletion, Actinide Transmutation, Fission Product Buildup and Decay, and Associated Radiation Source Terms," Sect. F7 of SCALE: A Modular Code System for Performing Standardized Computer Analyses for Licensing Evaluation, Vols. I-III, NUREG/CR-0200, Rev. 4 (ORNL/NUREG/CSD-2/R4) (April 1995). Available from Radiation Shielding Information Center at Oak Ridge National Laboratory as CCC-545.

12. Y. Naito, M. Kurosawa, and T. Kaneko, Data Book of the Isotopic Composition of Spent Fuel in Light Water Reactors, JAERI-M 94-034, Japan Atomic Energy Research Institute, 1994.

13. A. M. Bresesti et al., Post-Irradiation Analysis of Trino Vercelles Reactor Fuel Elements, EUR-4909e, Joint Nuclear Research Centre Ispra and Karlsruhe Establishments, 1972.

14. P. Barbero et al., Post-Irradiation Examination of the Fuel Discharged from the Trino Vercelles Reactor After the 2nd Irradiation Cycle, Nuclear Science and Technology, EUR5605e, Joint Research Centre Ispra and Karlsruhe Establishments, 1977.

15. S. D. Atkin, Destructive Examination of 3-Cycle LWR Fuel Rods from Turkey Point Unit 3 for the CLIMAX-Spent Fuel Test, HEDL-TME 80-89, Hanford Engineering Development Laboratory, 1981.

16. J. C. Ryman et al., Fuel Inventory and Afterheat Power Studies of Uranium-Fueled Pressurized Water Reactor Fuel Assemblies Using the SAS2 and ORIGEN-S Modules of SCALE with an ENDF/B-V Updated Cross Section Library, NUREG/CR-2397 (ORNL/CSD-90), U.S. Nuclear Regulatory Commission, September 1982.

17. The Evaluated Nuclear Data File, Versions $I V, V$, and $V I$ (ENDF'B-IV, $V$, and VI), maintained by the National Data Center at Brookhaven National Laboratory.

18. M. D. DeHart and S. M. Bowman, Validation of the SCALE Broad Structure 44-Group ENDF/B-V Cross-Section Library for Use in Criticality Safety Analyses, NUREG/CR-6102 (ORNL/TM-12460), U.S. Nuclear Regulatory Commission, 1994.

19. R. Q. Wright, "Fission Product Evaluations for ENDF/B-VI," Trans. Am. Nucl. Soc. 61, 398-399 (1990).

20. J. B. Melehan, Yankee Core Evaluation Program Final Report, WCAP-3017-6094, Westinghouse Electric Corp., 1971

21. O. W. Hermann, C. V. Parks, and J. P. Renier, "A Proposed Regulatory Guide Basis for Spent Fuel Decay Heat," Proc. Second Anmual International Conference on High Level Radioactive Waste Management, Vol. 2, Las Vegas, Nevada, April 28-May 3, 1991; also see O. W. Hermann, C. V. Parks, and J. P. Renier, Technical Support for a Proposed Decay 
Heat Guide Using SAS2H/ORIGEN-S Data, NUREG/CR-5625 (ORNL-6698), U.S. Nuclear Regulatory Commission, 1994.

22. J. W. Roddy et al., Physical and Decay Characteristics of Commercial LWR Spent Fuel, ORNL/TM-9591, Martin Marietta Energy Systems, Inc., Oak Ridge Natl. Lab., October 1985. 


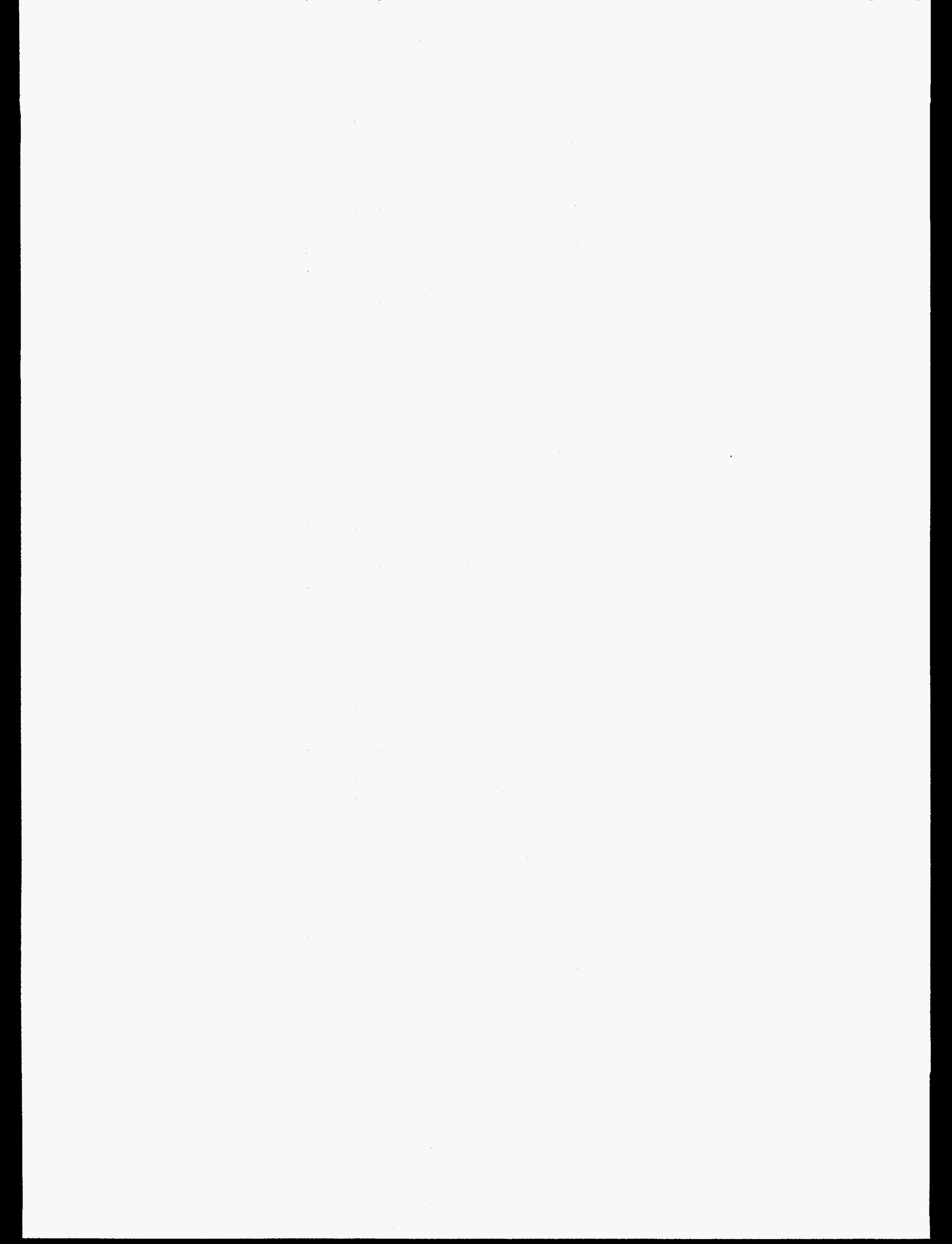




\section{APPENDIX A}

\section{DESCRIPTION OF THE SCALE SAS2H DEPLETION APPROACH}

SCALE is a well-established code system that has been widely used in away-from-reactor (AFR) applications for spent fuel characterization via the SAS2H analysis sequence. ${ }^{A .1}$ SAS2H is a multicode sequence that determines the isotopic composition of spent fuel using the ORIGEN-S code ${ }^{A .2}$ for depletion and decay calculations and a 1-D neutronics model of an LWR fuel assembly to prepare burnup-dependent cross sections for ORIGEN-S. Isotopic concentrations used in the subsequent spent fuel criticality calculations are based on the results of SAS2H calculations.

The SAS2H control module was originally developed for the SCALE code system to provide a sequence that generated radiation source terms for spent fuel and subsequently utilized these sources with a 1-D shielding analysis of a shipping cask. However, in addition to the calculation of source terms, SAS2H is now often used to obtain decay heat and spent fuel isotopics. Within the scope of validation activities described in this report, SAS2H is used solely for the prediction of spent fuel isotopics.

Six different modules are invoked by the SAS2H sequence for performing a complete fuel depletion analysis. The SCALE-4 system driver provides automated data handling and code execution for each step of the process. This procedure begins with the SCALE Material Information Processor ${ }^{A .3}$ which generates number densities and related information, prepares geometry data for resonance self-shielding and flux-weighting cell calculations, and creates data input files for the cross-section processing codes. BONAMI ${ }^{\mathrm{A} .4}$ applies the Bondarenko method of resonance self-shielding for nuclides which have Bondarenko data included in the cross-section library. NITAWL-II ${ }^{\text {A.S }}$ performs Nordheim resonance self-shielding corrections for nuclides that have resonance parameters included with their cross-section data. XSDRNPM ${ }^{\text {A.6 }}$ is a 1-D discrete ordinates code that performs radiation transport calculations based on geometric data passed to it by SAS2H and produces cell-weighted cross sections for fuel depletion calculations. The COUPLE code $^{\mathrm{A} .7}$ updates cross-section constants included on the ORIGEN-S nuclear data library with data from the cell-weighted cross-section library produced by XSDRNPM. COUPLE also uses the XSDRNPM-computed weighting spectrum to update nuclide cross 
sections for remaining nuclides. Finally, the ORIGEN-S code is used to perform nuclide generation and depletion calculations for a specified reactor fuel history.

The process used by $\mathrm{SAS} 2 \mathrm{H}$ in calculation of spent fuel isotopics is illustrated schematically in Fig. A.1. The calculation starts with input-specified data describing a fuel assembly as it is initially loaded into a reactor. The initial composition, average temperatures, geometry, and time-dependent specific power of the fuel assembly are required. The SAS2H sequence performs 1-D neutron transport analysis of the reactor fuel assembly using XSDRNPM and a two-part procedure with two separate unit-cell-lattice models. The first model (Path A of Fig. 1) is a unit fuel-pin cell from which cell-weighted cross sections are obtained. The second model (Path B of Fig. 1) represents a larger unit cell (e.g., an assembly) within an infinite lattice. The larger unit cell zones can be structured for different assembly designs to account for assembly-specific attributes (i.e., water holes, burnable poison rods, etc.). Problemdependent resonance self-shielding of cross sections is performed prior to each XSDRNPM calculation using the BONAMI and NITAWL-II codes. The neutron flux spectrum obtained from the second (assembly) unit-cell model is used to determine the appropriate nuclide cross sections for the burnup-dependent fuel composition. The cross sections derived from XSDRNPM calculations at each time step are used in an ORIGEN-S point-depletion computation that produces the burnup-dependent fuel compositions to be used in the next spectrum calculation. This sequence is repeated in user-specified burnup steps for a complete assembly operating history. The buildup and decay of nuclides in the fuel assembly is then computed by ORIGEN-S in a final pass based on the assembly's cooling time (i.e., the period of time after final exposure time). Note that ORIGEN-S calculations have no spatial dependence. The neutron flux used to produce the ORIGEN-S cross sections is based on a radial average of an infinitely long uniform assembly with characteristics per input specifications. These specifications (e.g., burnup, specific power, moderator temperature, etc.) can be representative of any axial location along the fuel assembly or an axial average of the fuel assembly.

More than 1000 nuclides are tracked by ORIGEN-S during depletion and decay calculations. (Note that ORIGEN-S tracks all decay chains, but does not account for the loss of volatile isotopes; however, any released nuclides represent an insignificant fraction of the total fission-product inventory, and their inclusion should have an insignificant effect on the isotopic 


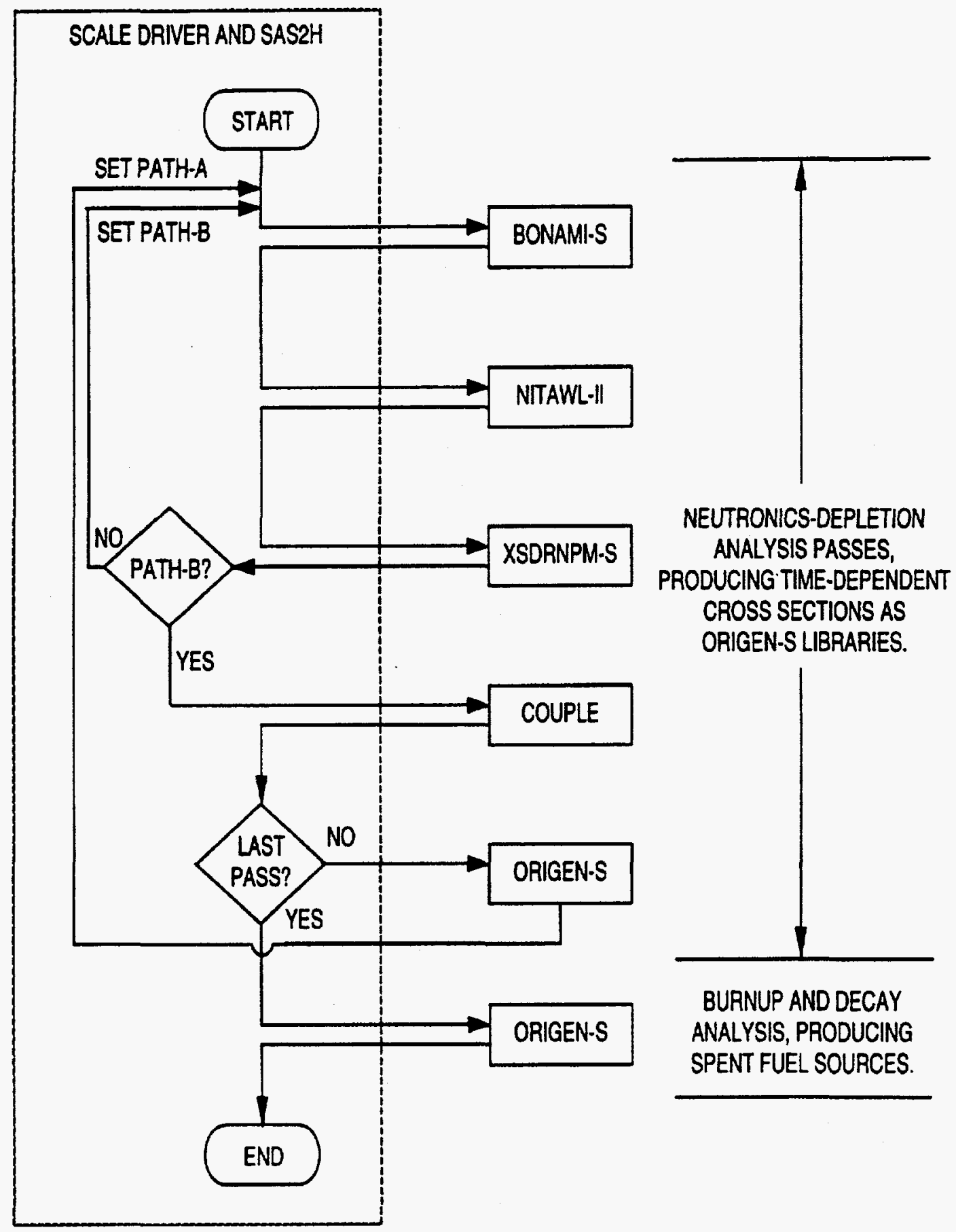

Fig. A.1. Flow path invoked in SAS2H depletion and decay sequences. 
calculations.) Burnup-dependent cross sections are processed by SAS2H only for a select set of user-specified nuclides. These nuclides are those found to be most important for depletion calculations in LWR fuels and are listed in Table A.1. Cross sections for remaining isotopes are obtained from the ORIGEN-S one-group LWR library and are adjusted with burnup using ORIGEN-S spectral parameters (THERM, RES, and FAST) ${ }^{\text {A.2 }}$ calculated using fluxes determined by XSDRNPM. The ORIGEN-S one-group LWR library available in SCALE-4 has been updated to use cross sections from the SCALE-4 27-group burnup library for all 193 nuclides in that library. The update was performed by extracting one-group cross sections from the output of a lowburnup LWR-type fuel.

Table A.1. List of fuel nuclides automatically included by SAS2 for neutronics processing ${ }^{a}$

\begin{tabular}{lcc}
\hline${ }^{135} \mathrm{Xe}$ & ${ }^{238} \mathrm{Pu}$ & ${ }^{242 \mathrm{~m}} \mathrm{Am}$ \\
${ }^{133} \mathrm{Cs}$ & ${ }^{399} \mathrm{Pu}$ & ${ }^{243} \mathrm{Am}$ \\
${ }^{234} \mathrm{U}$ & ${ }^{240} \mathrm{Pu}$ & ${ }^{242} \mathrm{Cm}$ \\
${ }^{255} \mathrm{U}$ & ${ }^{241} \mathrm{Pu}$ & ${ }^{243} \mathrm{Cm}$ \\
${ }^{236} \mathrm{U}$ & ${ }^{242} \mathrm{Cm}$ \\
${ }^{238} \mathrm{U}$ & ${ }^{241} \mathrm{Pu}$ & $1 /$-absorber \\
\hline
\end{tabular}

aUnless overridden by user input, these nuclides are added to the initial fuel mixture with a number density of $10^{-20}$ atoms $/ \mathrm{b}-\mathrm{cm}$.

${ }^{b}$ Used to calculate the THERM parameters applied in ORIGEN-S (see Sect. F7 of ref. 1). 


\section{References}

A.1 O. W. Hermann and C. V. Parks, "SAS2H: A Coupled One-Dimensional Depletion and Shielding Analysis Code," Sect. S2 of SCALE: A Modular Code System for Performing Standardized Computer Analyses for Licensing Evaluation, NUREG/CR-0200, Rev. 4 (ORNL/NUREG/CSD-2/R4), Vols. I, II, and III (April 1995). Available from Radiation Shielding Information Center as CCC-545.

A.2 O. W. Hermann and R. M. Westfall, "ORIGEN-S: A SCALE System Module to Calculate Fuel-Depletion, Actinide Transmutation, Fission Product Buildup and Decay, and Associated Radiation Source Terms," Sect. F7 of SCALE: A Modular Code System for Performing Standardized Computer Analyses for Licensing Evaluation, NUREG/CR-0200, Rev. 4 (ORNL/NUREG/CSD-2/R4), Vols. I, II, and III (April 1995). Available from Radiation Shielding Information Center as CCC-545.

A.3 N. F. Landers et al., "The Material Information Processor for SCALE," Sect. M7 of SCALE: A Modular Code System for Performing Standardized Computer Analyses for Licensing Evaluation, NUREG/CR-0200, Rev. 4 (ORNL/NUREG/CSD-2/R4), Vols. I, II, and III (April 1995). Available from Radiation Shielding Information Center as CCC-545.

A.4 N. M. Greene, "BONAMI: Resonance Self-Shielding by the Bondarenko Method," Sect. F1 of SCALE: A Modular Code System for Performing Standardized Computer Analyses for Licensing Evaluation, NUREG/CR-0200, Rev. 4 (ORNL/NUREG/CSD-2/R4), Vols. I, II, and III (April 1995). Available from Radiation Shielding Information Center as CCC-545.

A.5 N. M. Greene, "NITAWL-II: SCALE System Module for Performing Resonance Shielding and Working Library Production," Sect. F2 of SCALE: A Modular Code System for Performing Standardized Computer Analyses for Licensing Evalwation, NUREG/CR-0200, Rev. 4 (ORNL/NUREG/CSD-2/R4), Vols. I, II, and III (April 1995). Available from Radiation Shielding Information Center as CCC-545.

A.6 N. M. Greene and L. M. Petrie, "XSDRNPM: A One-Dimensional Discrete-Ordinates Code for Transport Analysis," Sect. F3 of SCALE: A Modular Code System for Performing Standardized Computer Analyses for Licensing Evaluation, NUREG/CR-0200, Rev. 4 (ORNL/NUREG/CSD-2/R4), Vols. I, II, and III (April 1995). Available from Radiation Shielding Information Center as CCC-545.

A.7 O. W. Hermann, "COUPLE: SCALE System Module to Process Problem-Dependent Cross Sections and Neutron Spectral Data for ORIGEN-S Analyses," Sect. F6 of SCALE: A Modular Code System for Performing Standardized Computer Analyses for Licensing Evaluation, NUREG/CR-0200, Rev. 4 (ORNL/NUREG/CSD-2/R4), Vols. I, II, and III (April 1995). Available from Radiation Shielding Information Center as CCC-545. 


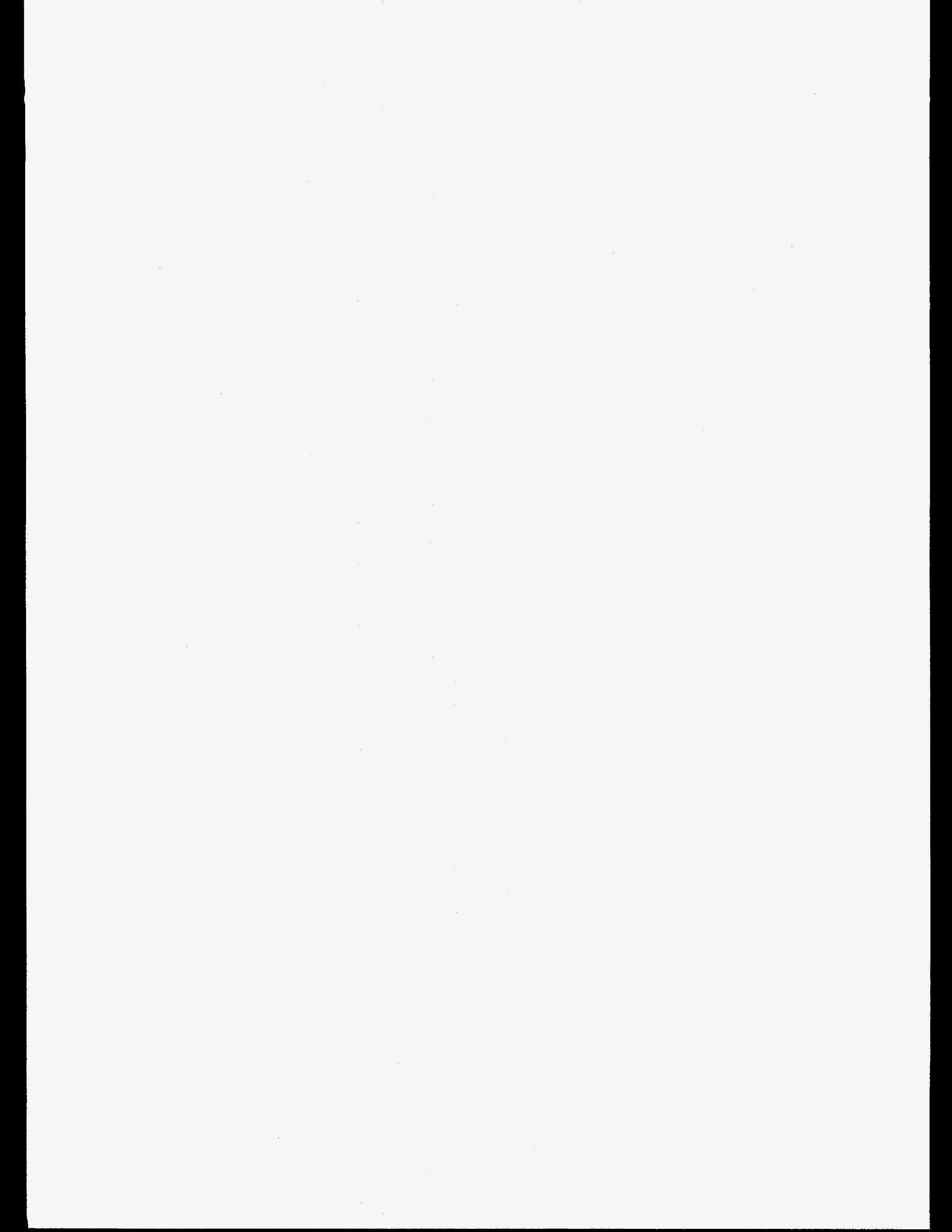




\section{APPENDIX B}

\section{INPUT LISTINGS FOR TRINO VERCELLES SAS2H DEPLETION CALCULATION}

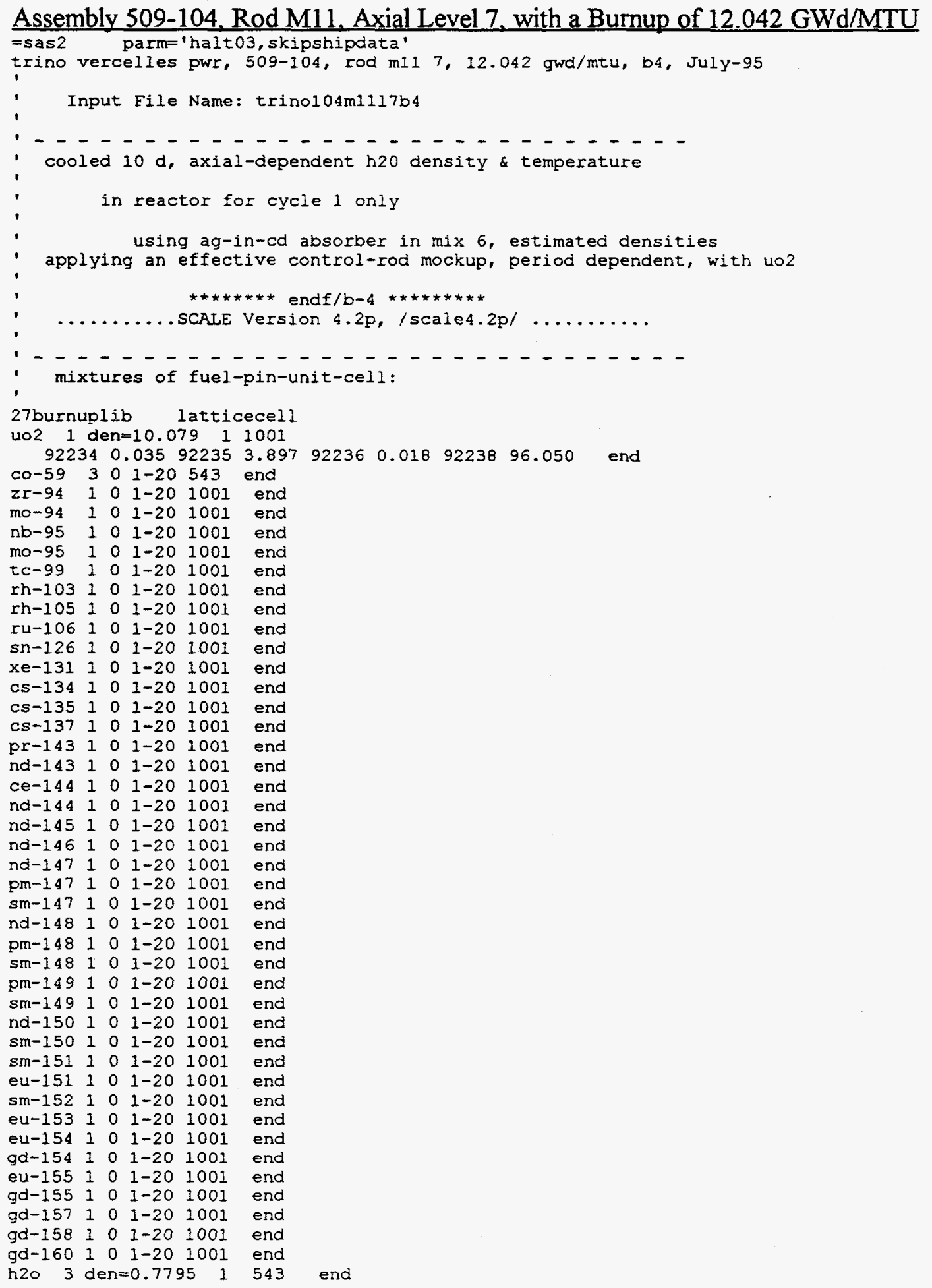




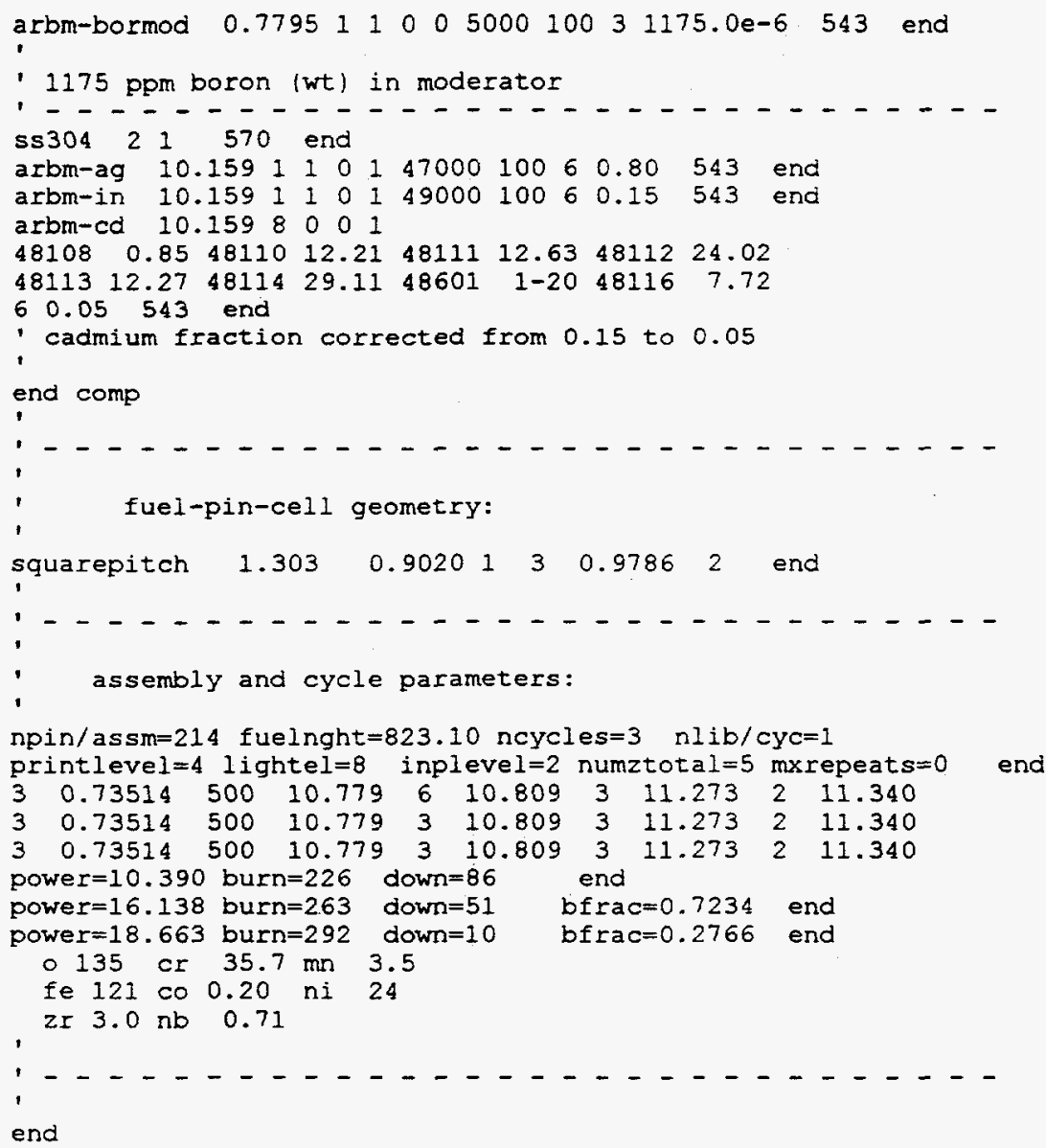




\section{Assembly 509-032, Rod E11, Axial Level 4, with a Burnup of 15.377 GWd/MTU}

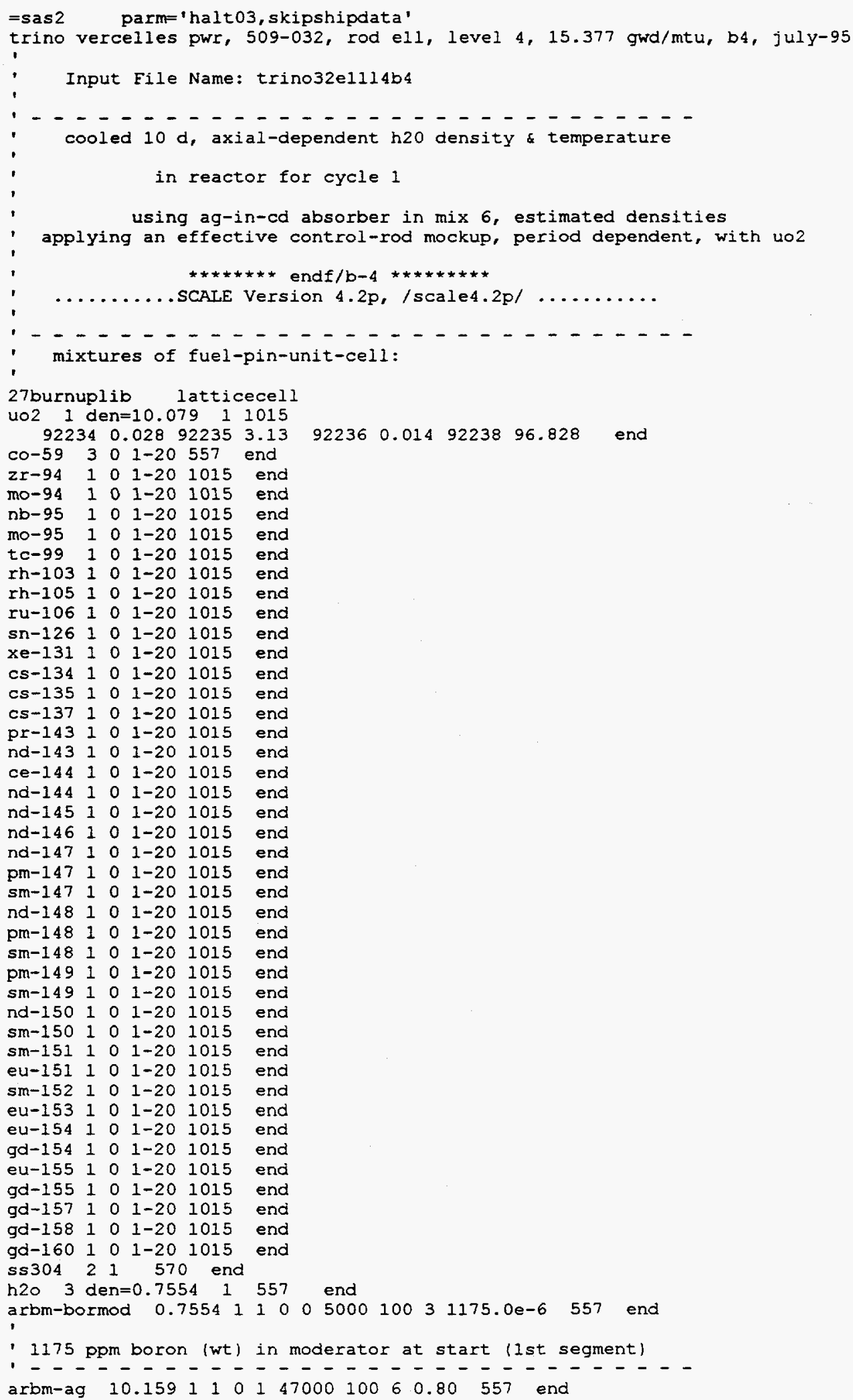




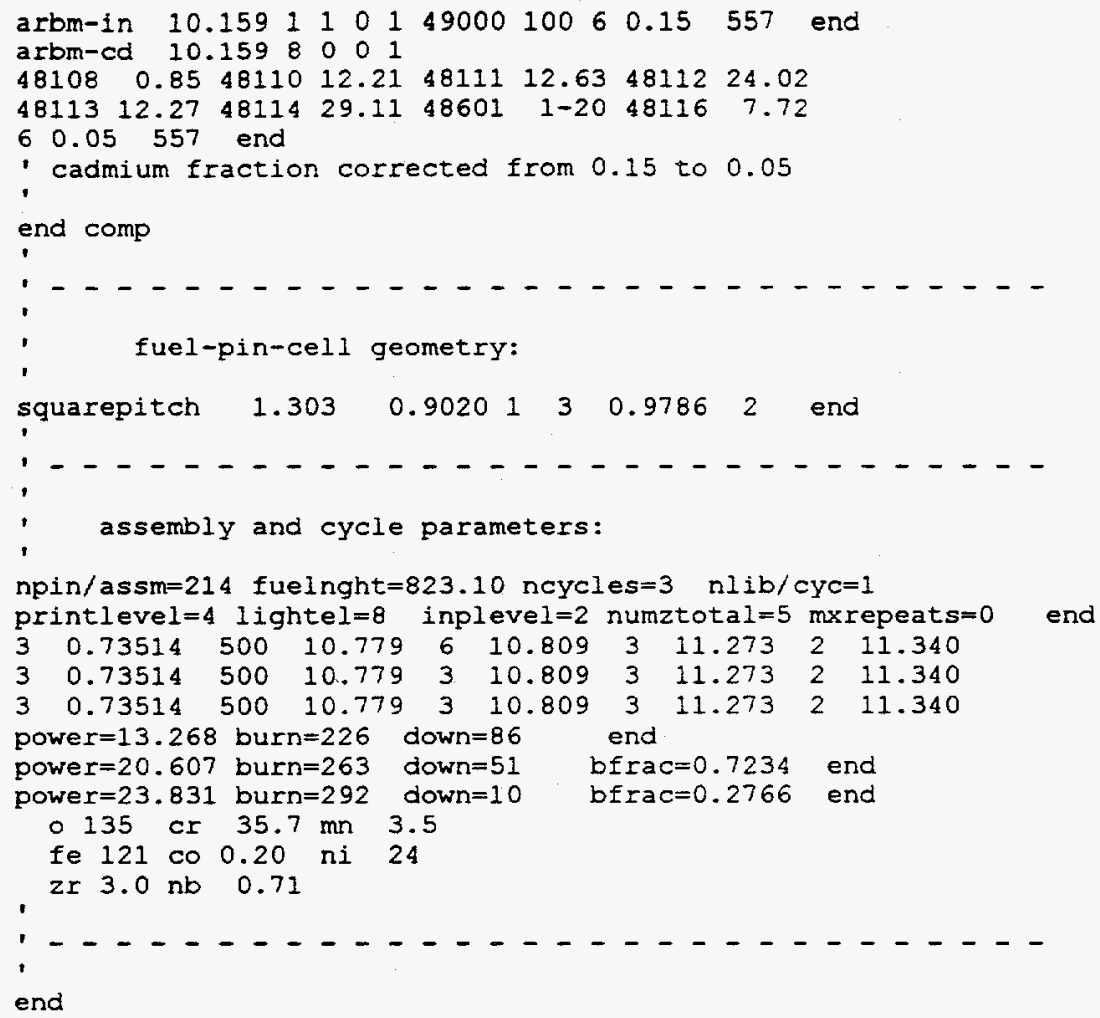




\section{Assembly 509-032. Rod E11. Axial Level 7, with a Burnup of $15.898 \mathrm{GWd} / \mathrm{MTU}$}

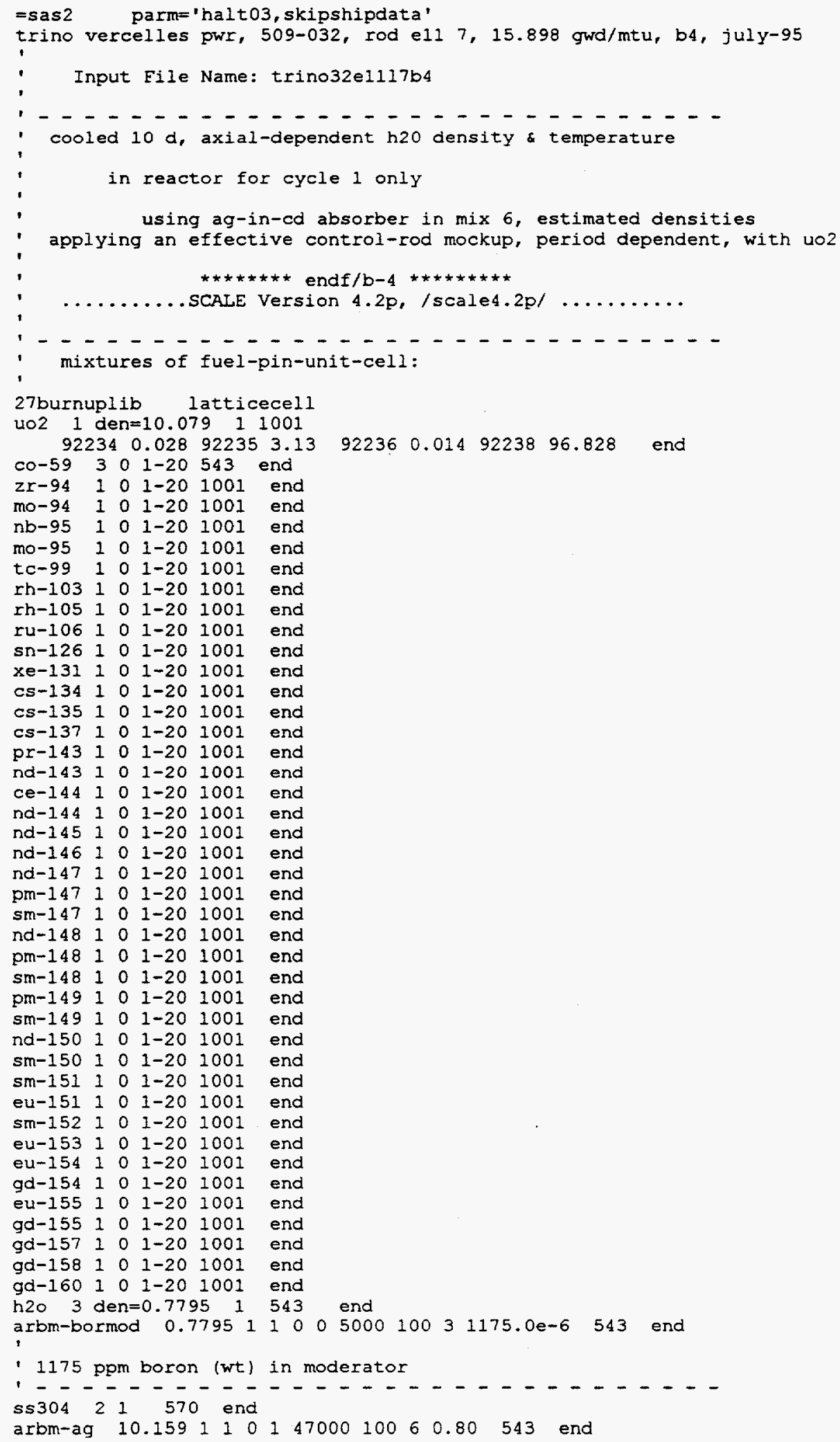




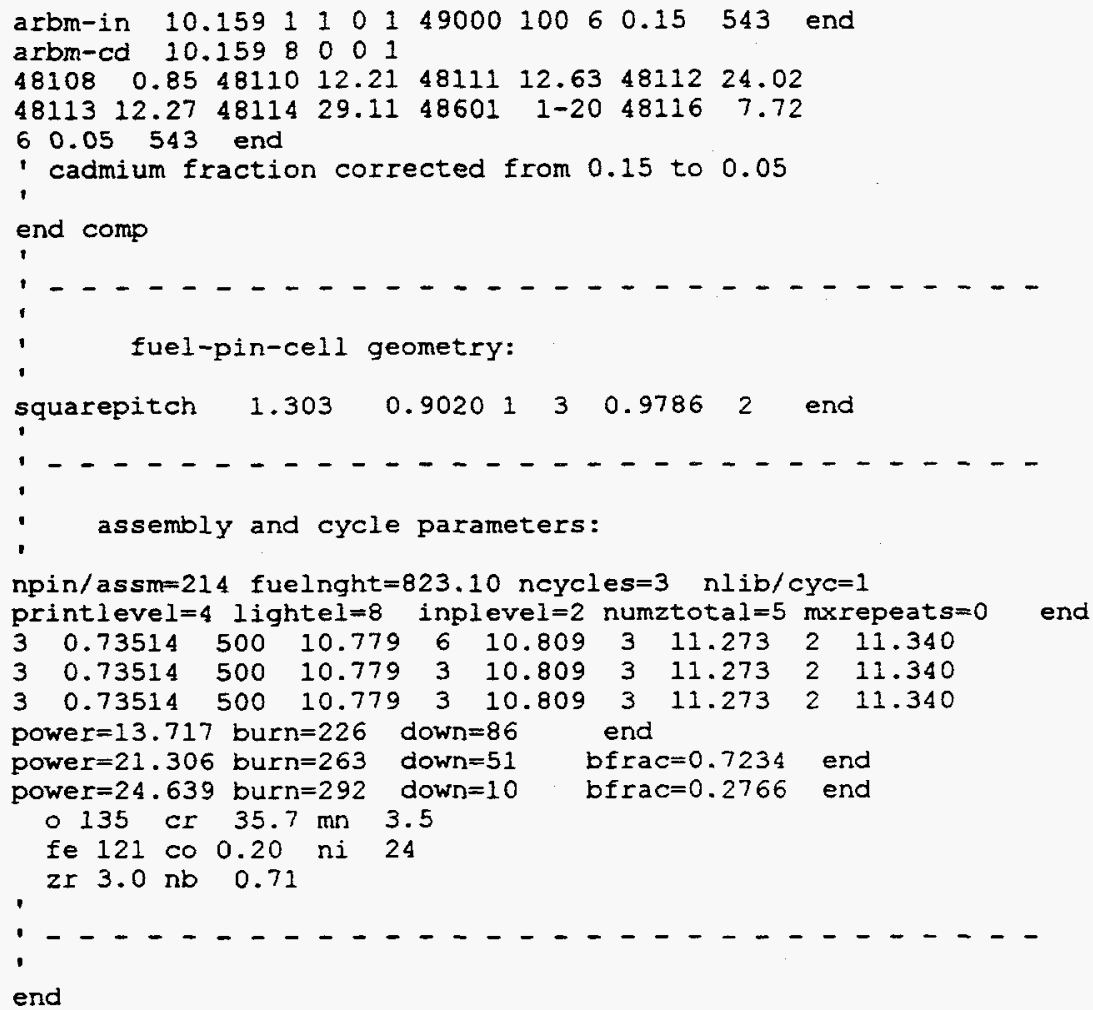




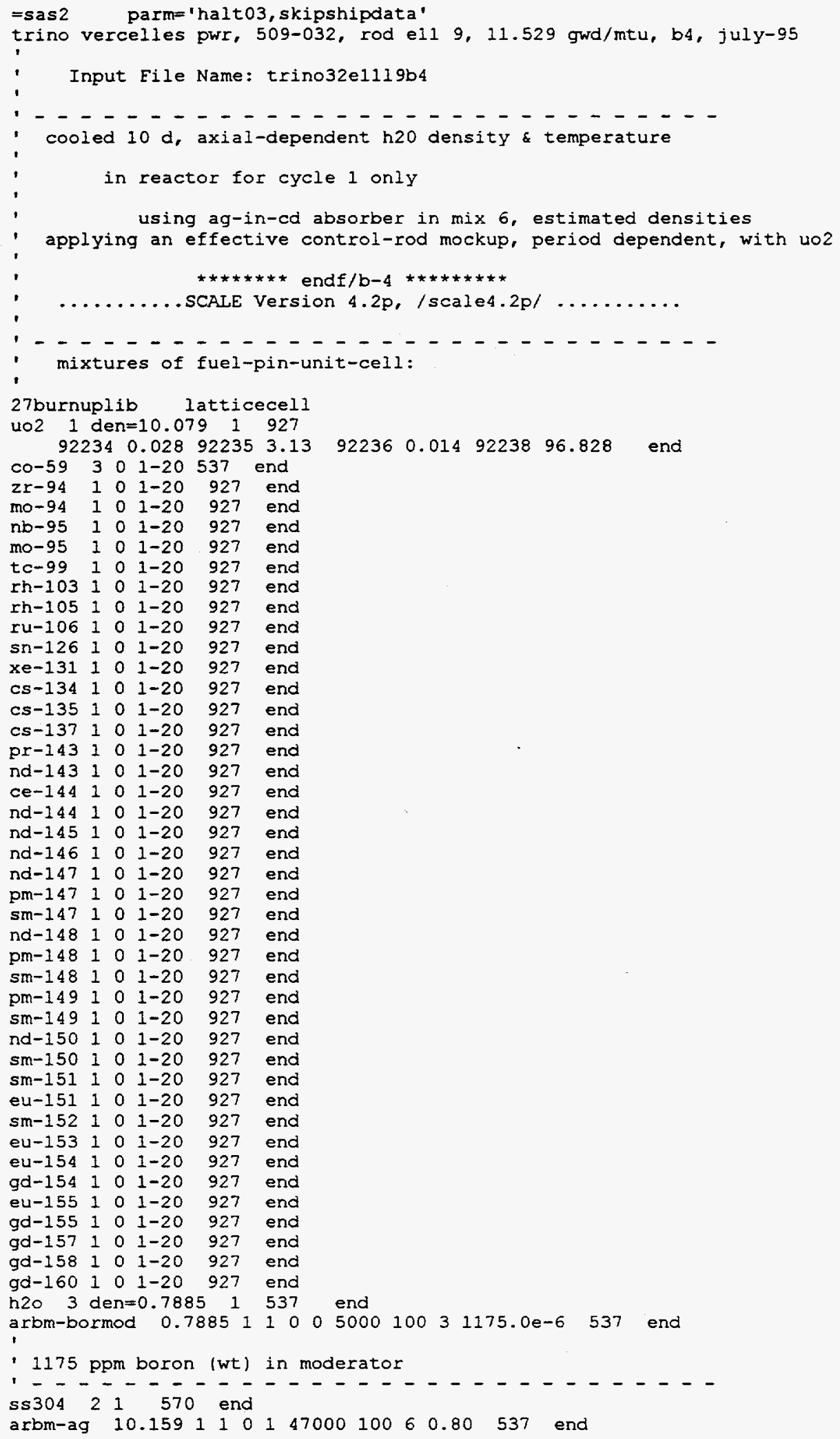




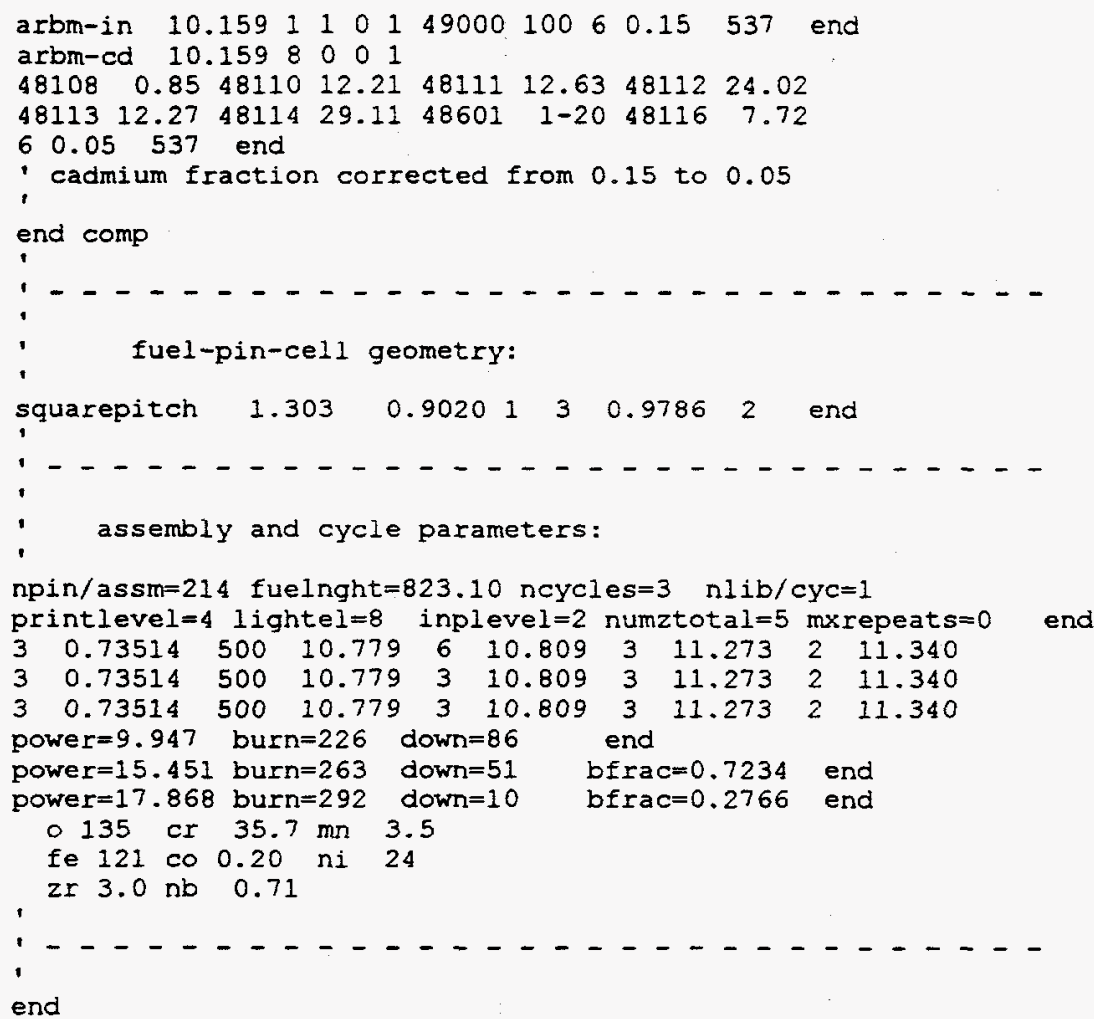




\section{Assembly 509-069. Rod E11, Axial Level 1, with a Burnup of 12.859 GWd/MTU}

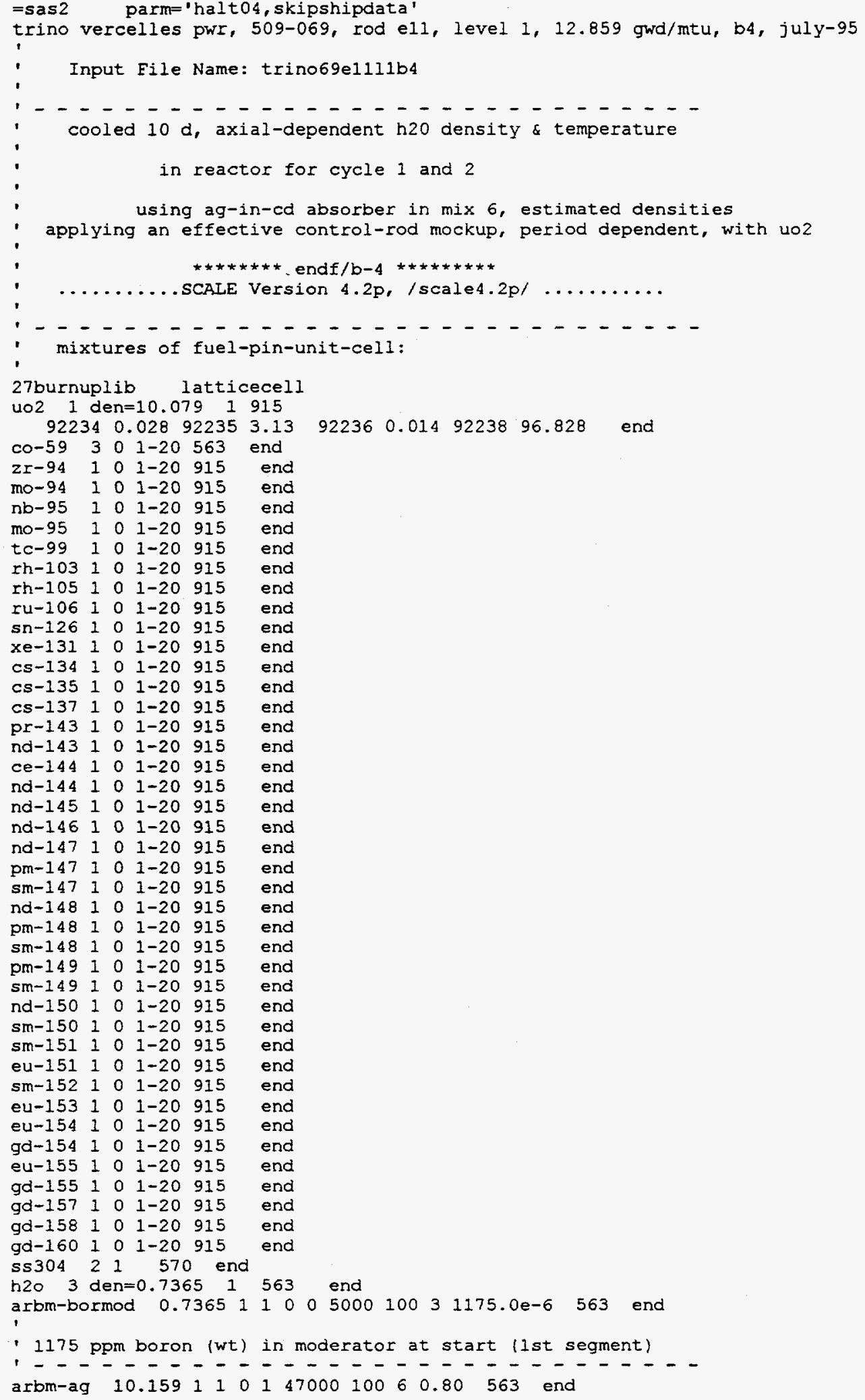




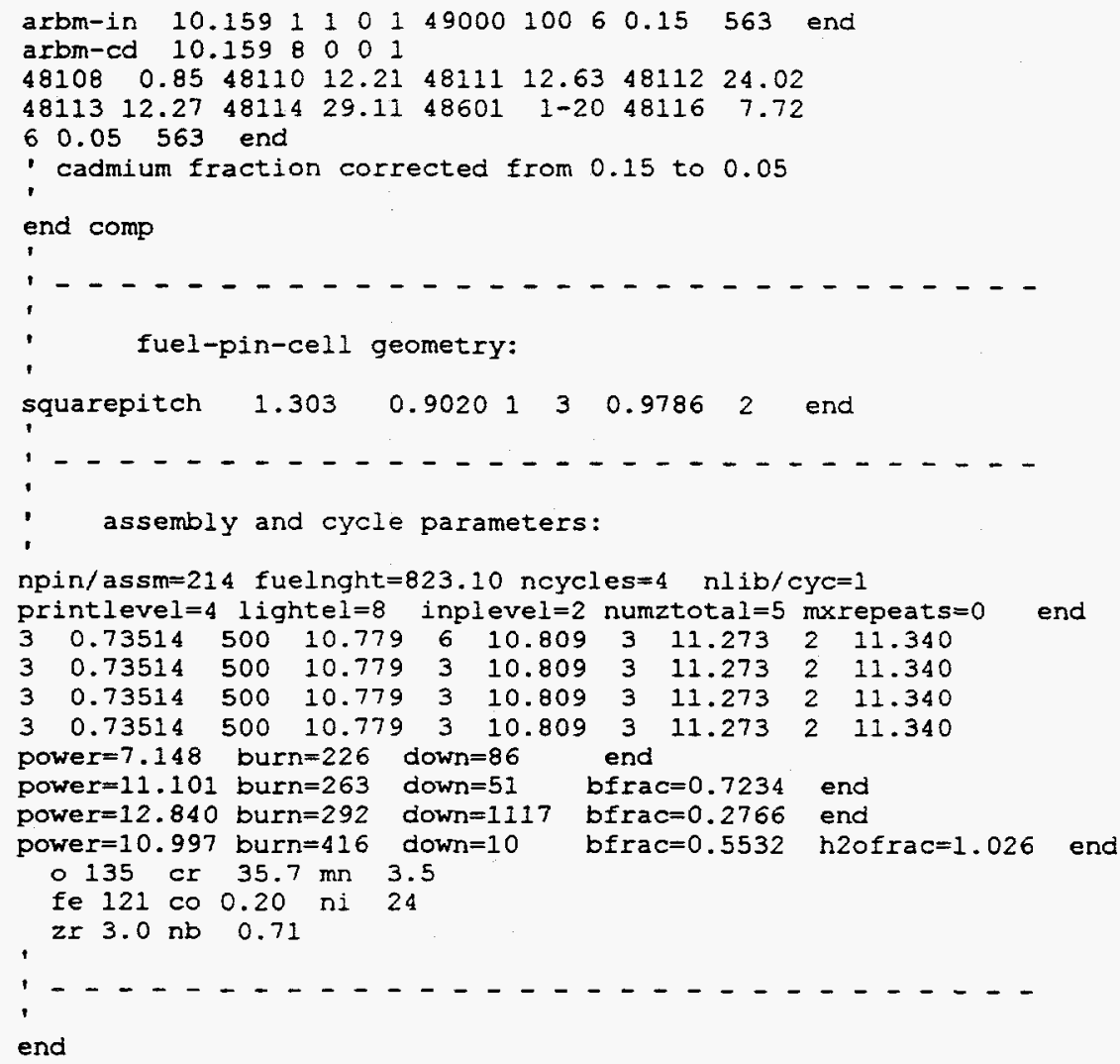




\section{Assembly 509-069, Rod E11, Axial Level 2, with a Burnup of 20.602 GWd/MTU}

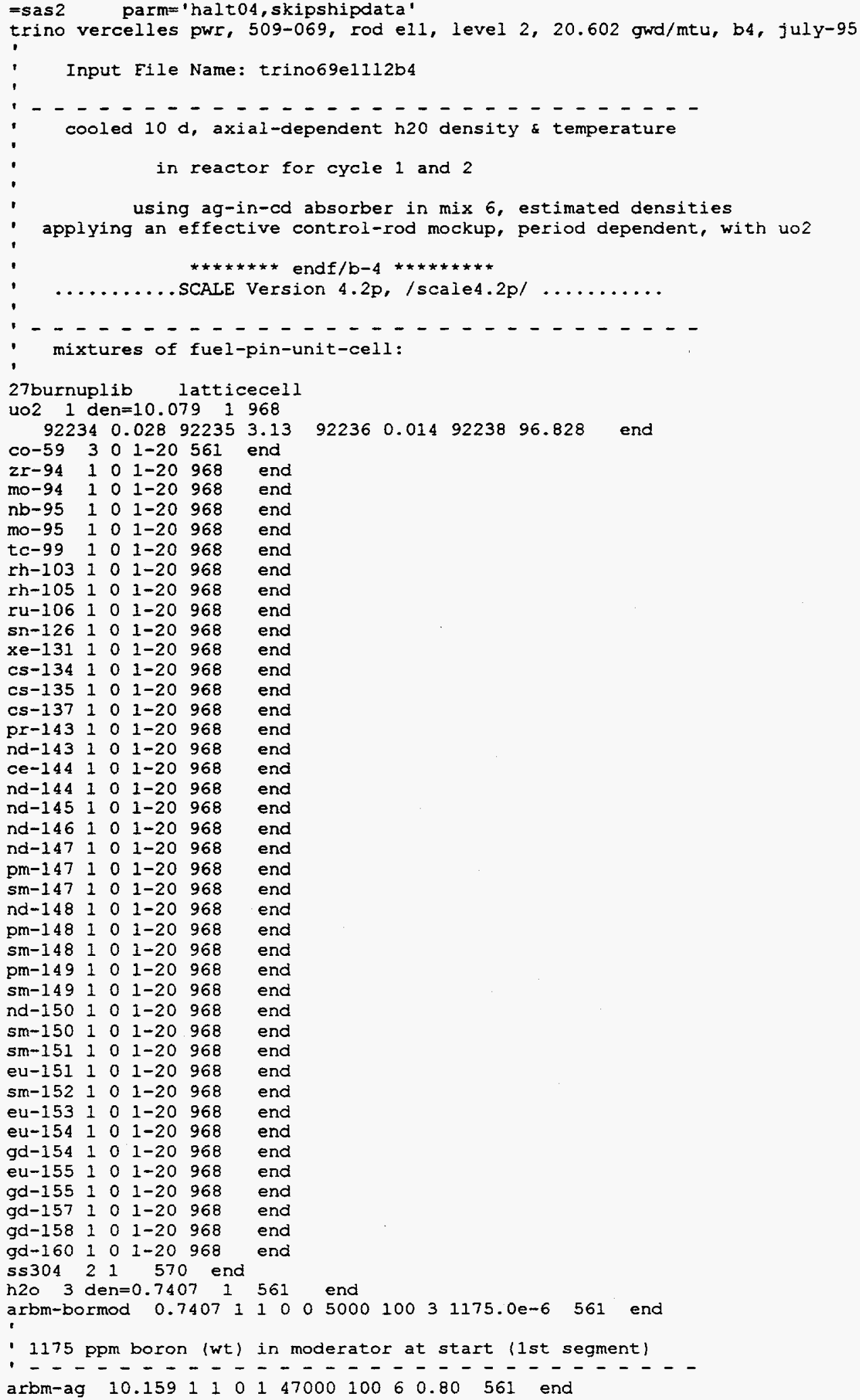




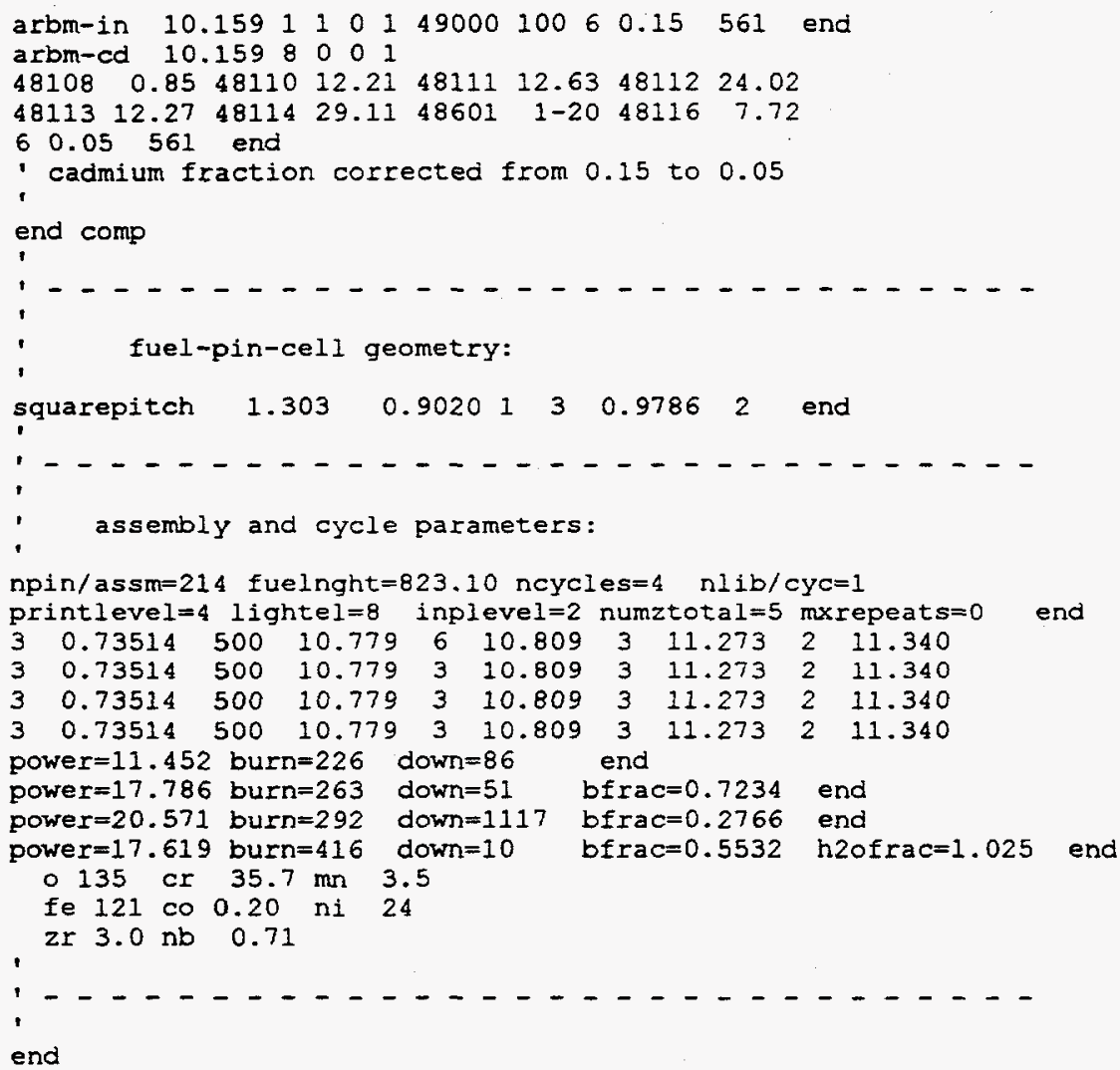




\section{Assembly 509-069. Rod E11. Axial Level 4, with a Burnup of 23.718 GWd/MTU}

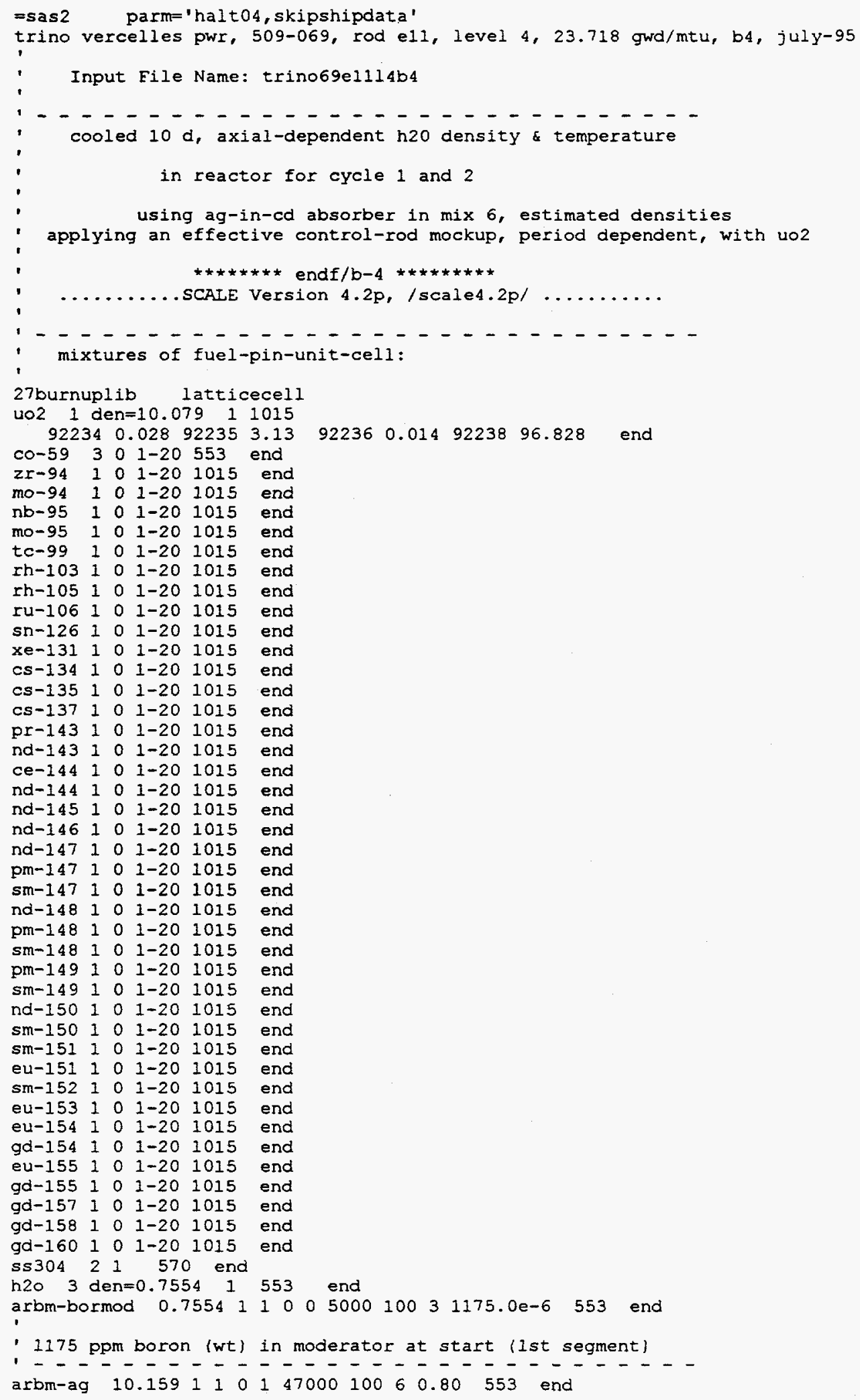




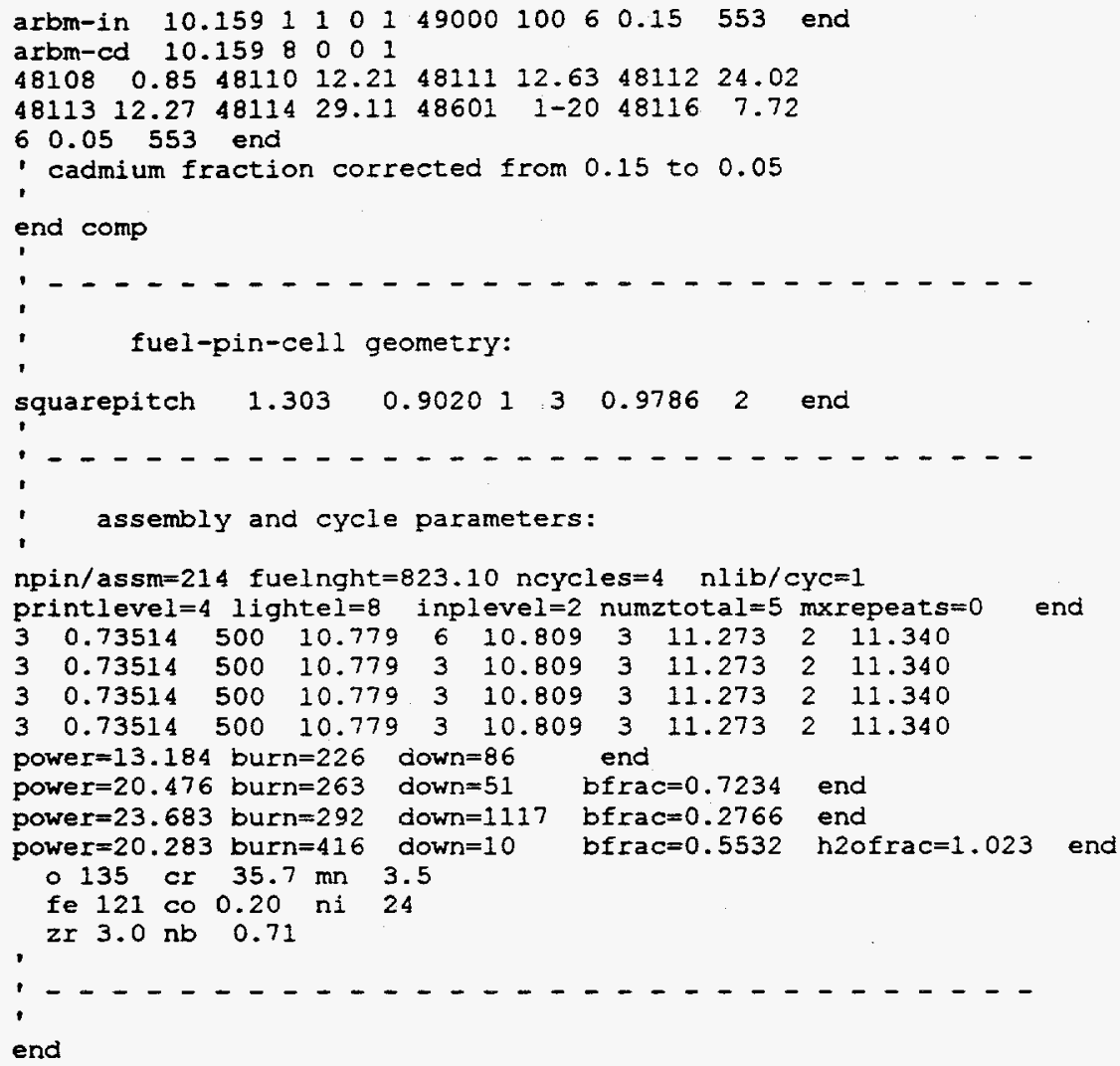




\section{Assembly 509-069, Rod E11, Axial Level 7, with a Burnup of 24.304 GWd/MTU}

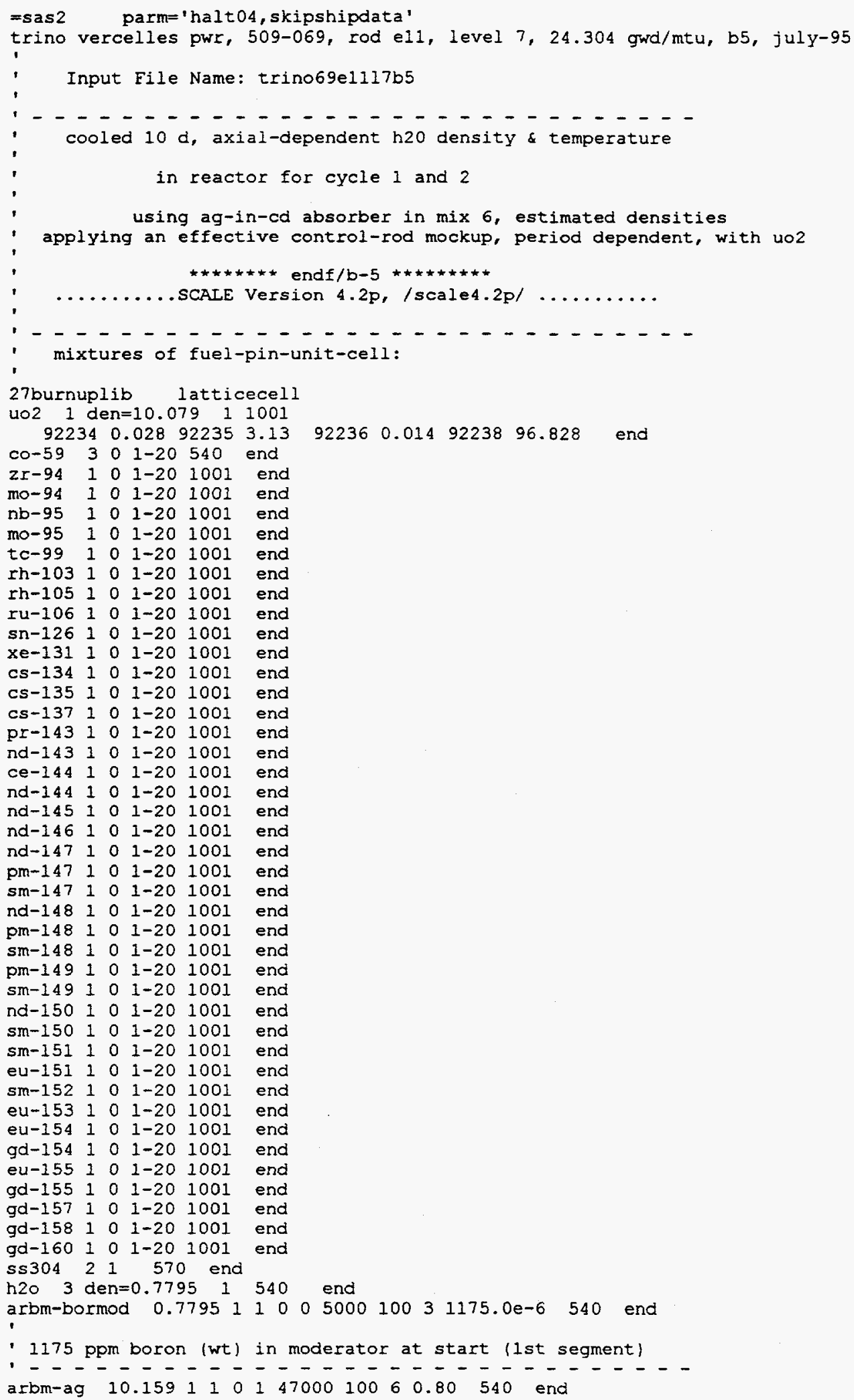




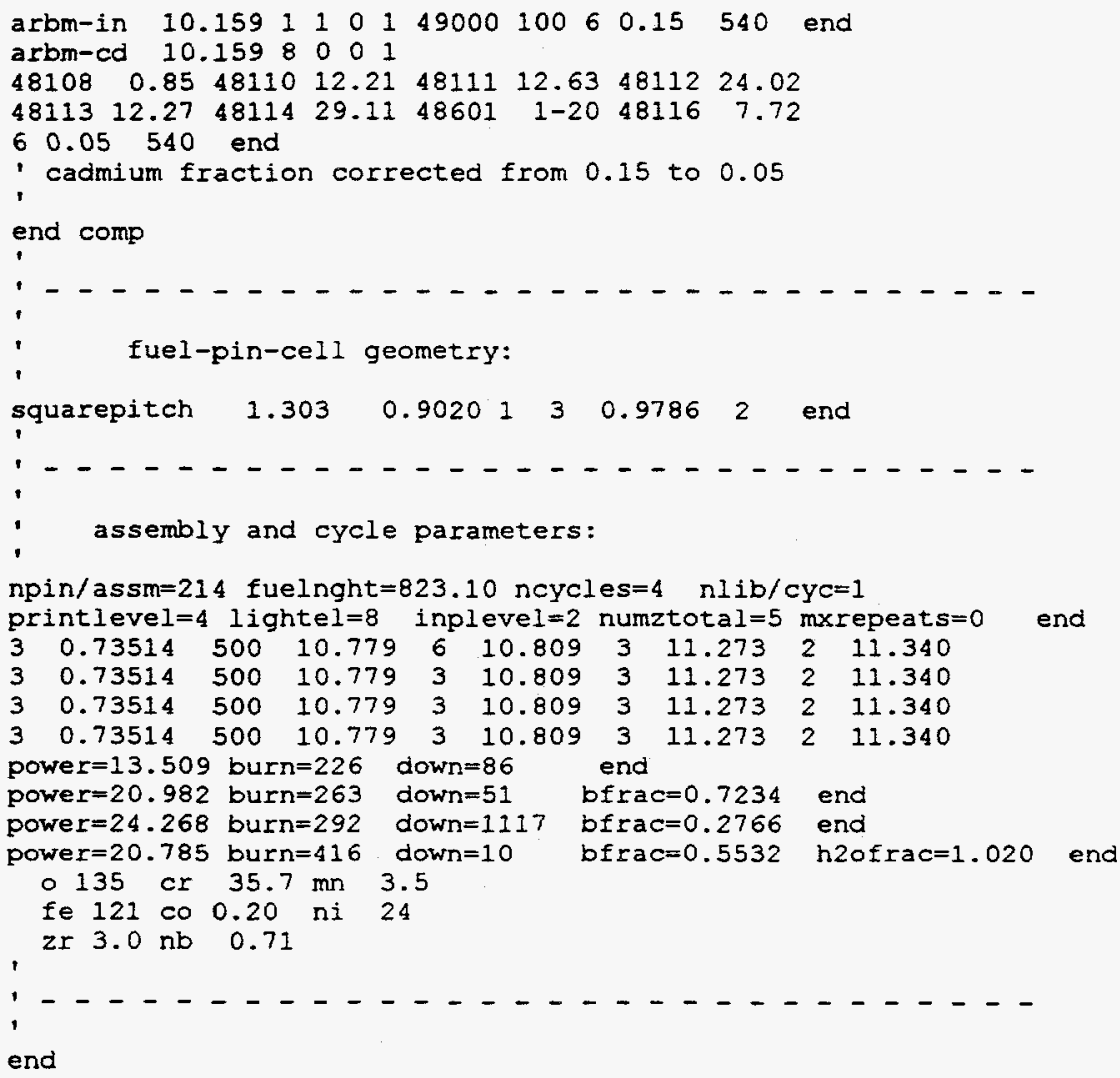




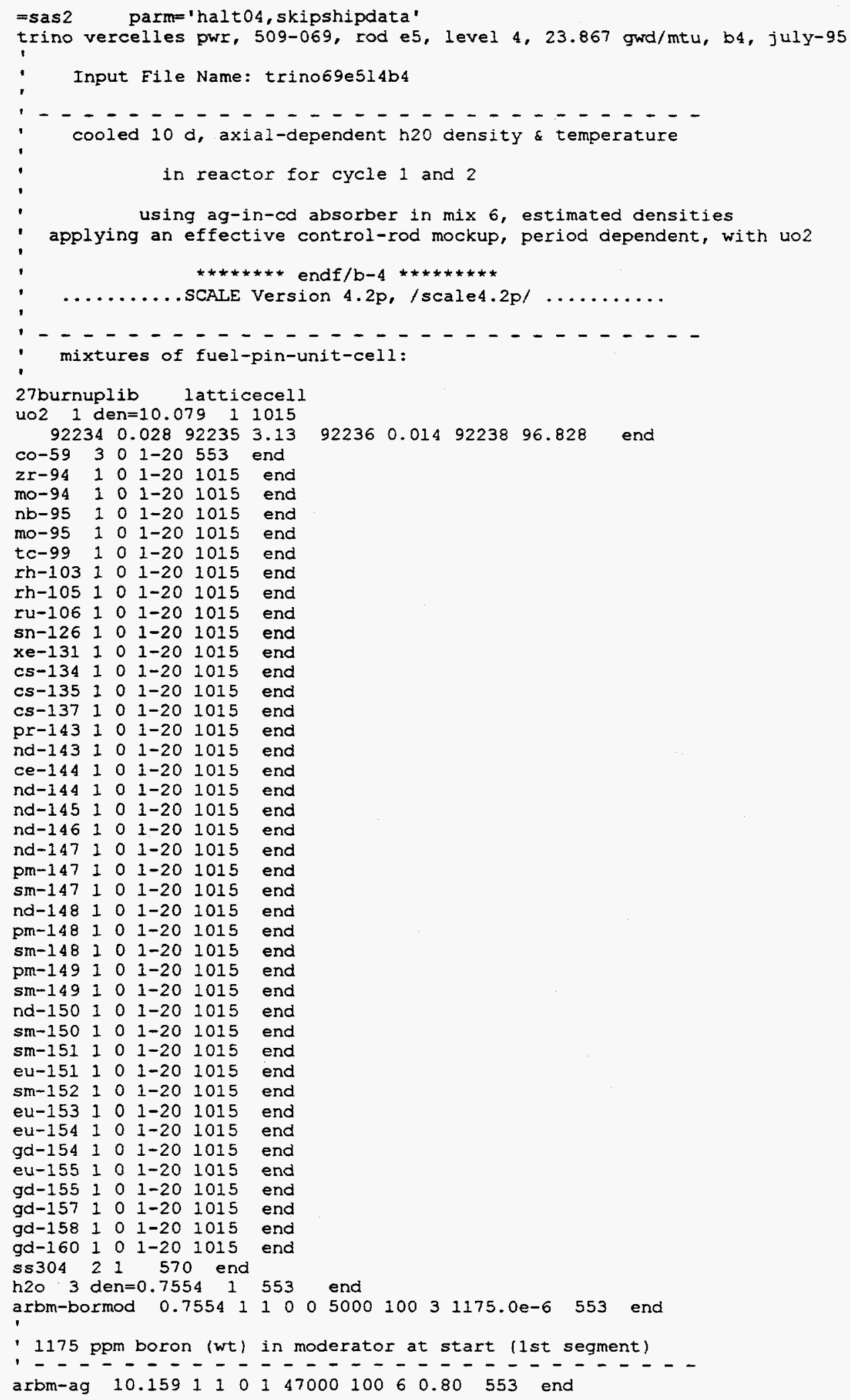




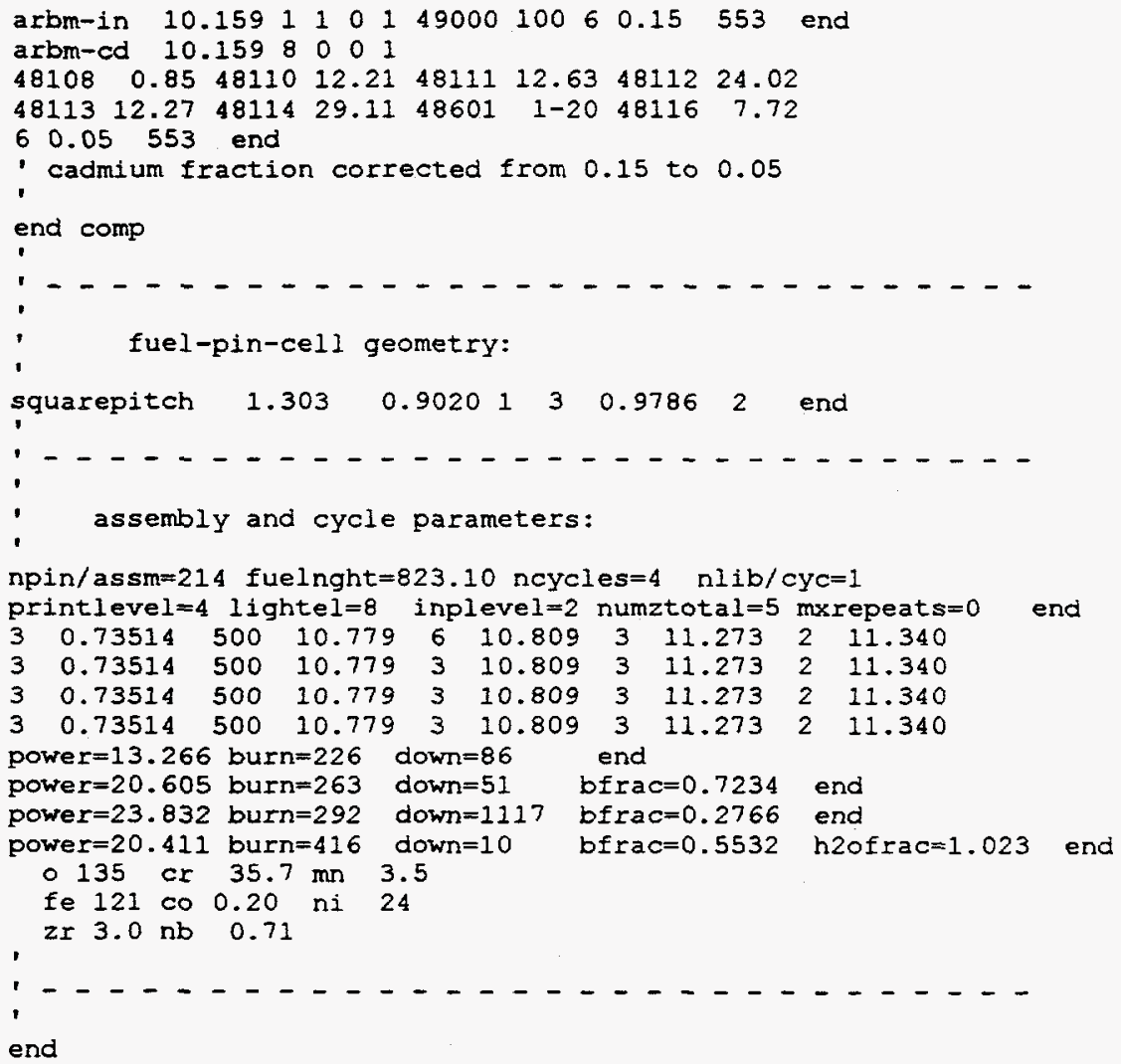




\section{Assembly 509-069, Rod E5, Axial Level 7, with a Burnup of 24.548 GWd/MTU}

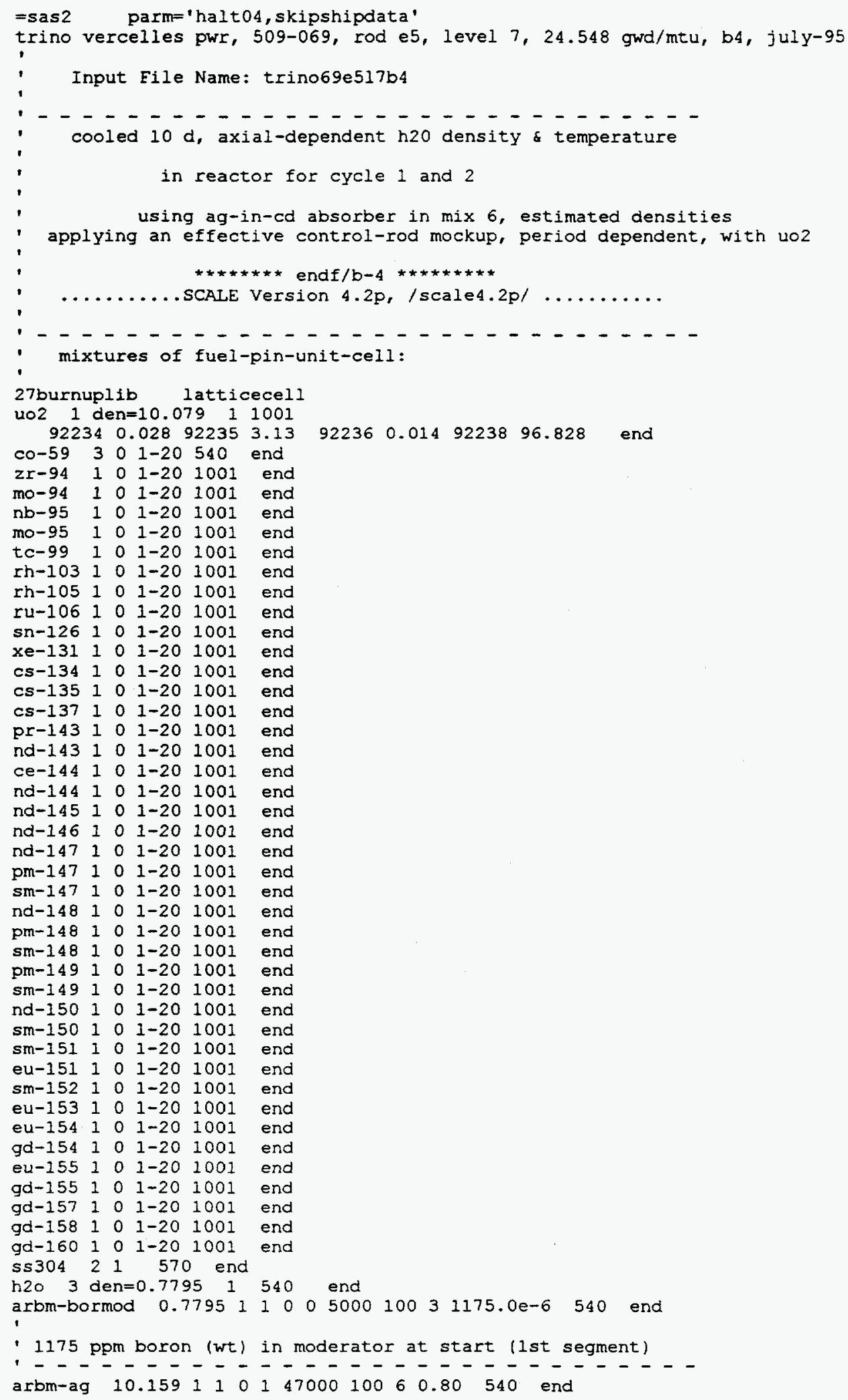




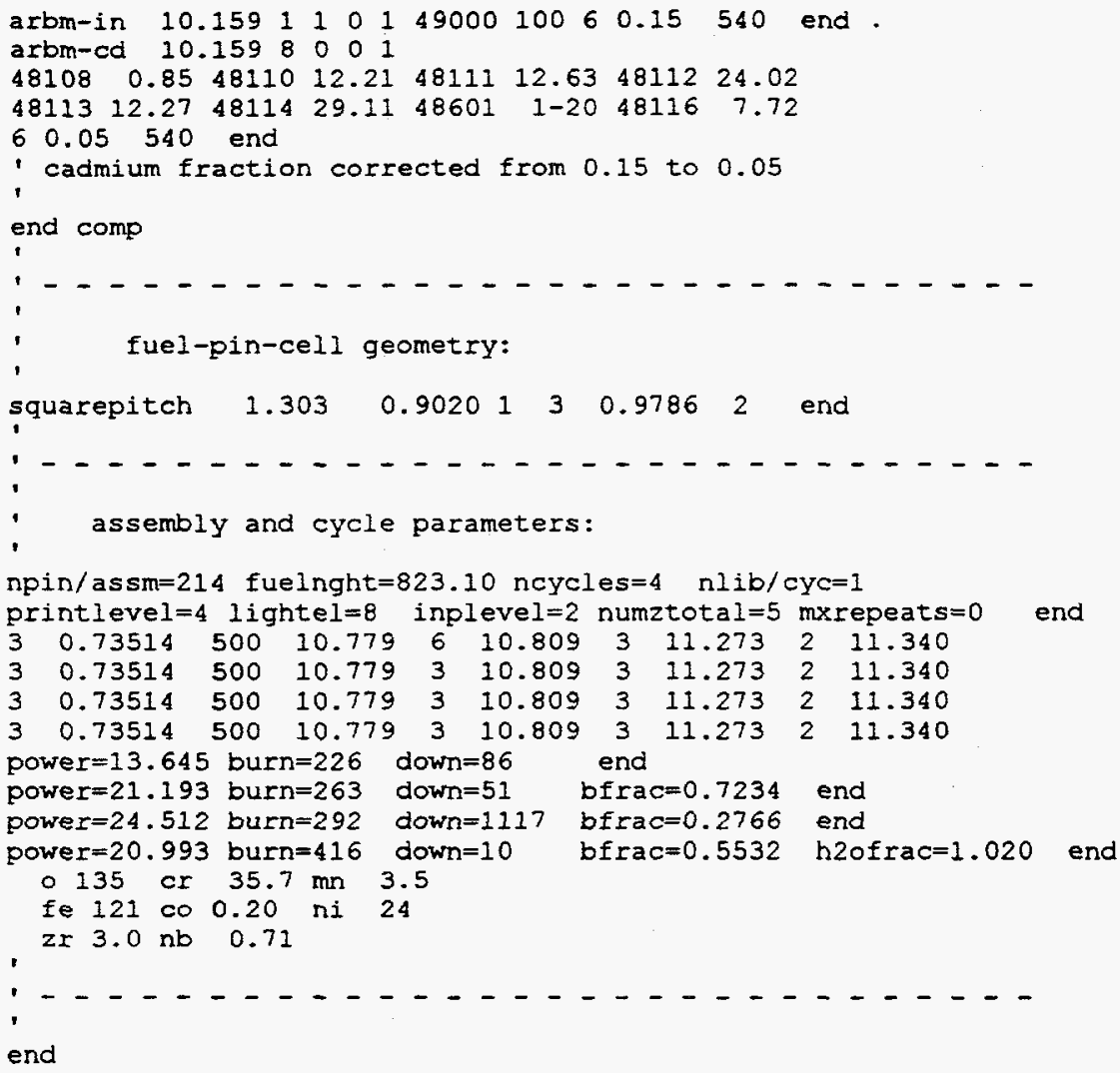




\section{Assembly 509-069, Rod L11, Axial Level 4, with a Burnup of 23.928 GWd/MTU}

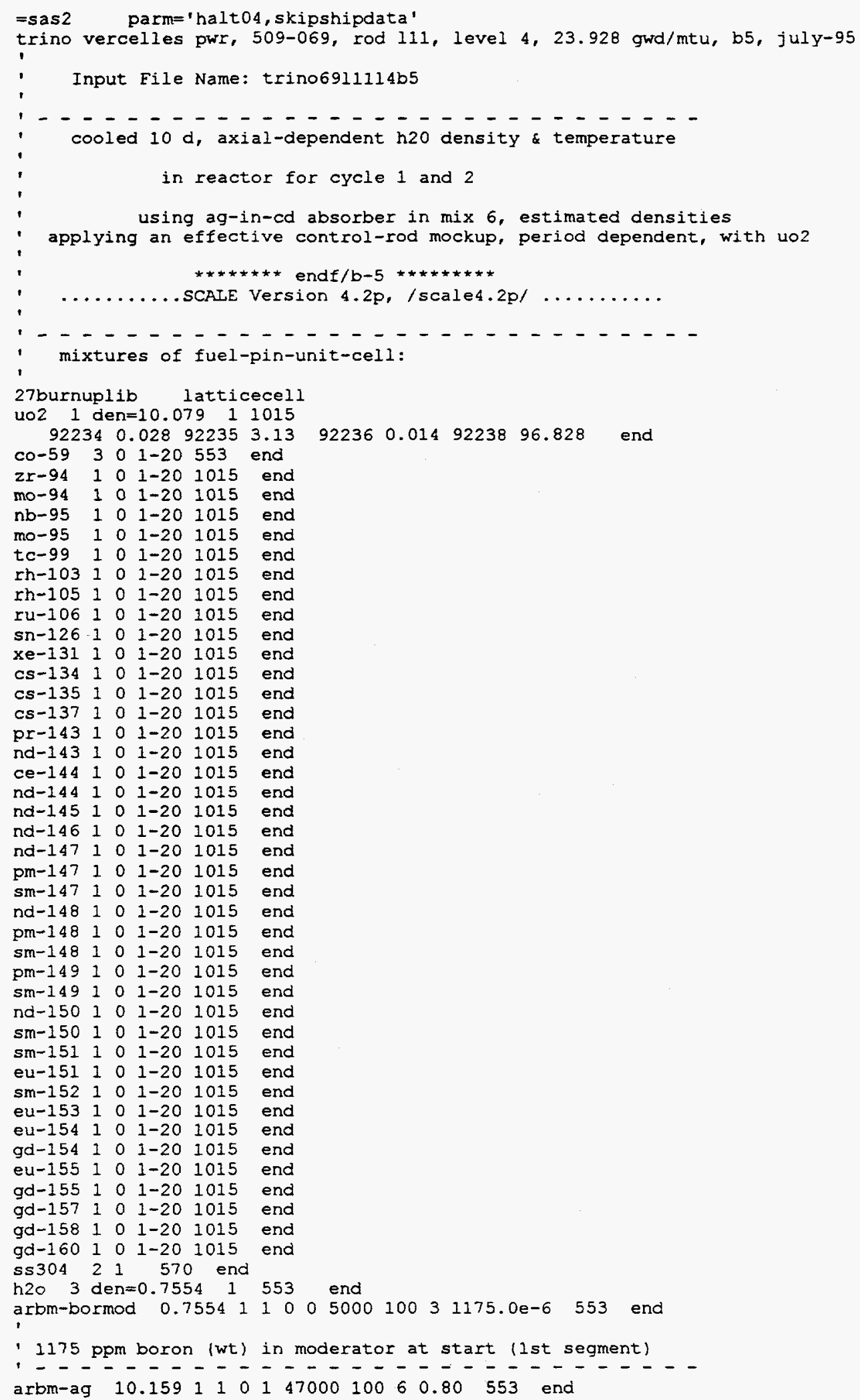




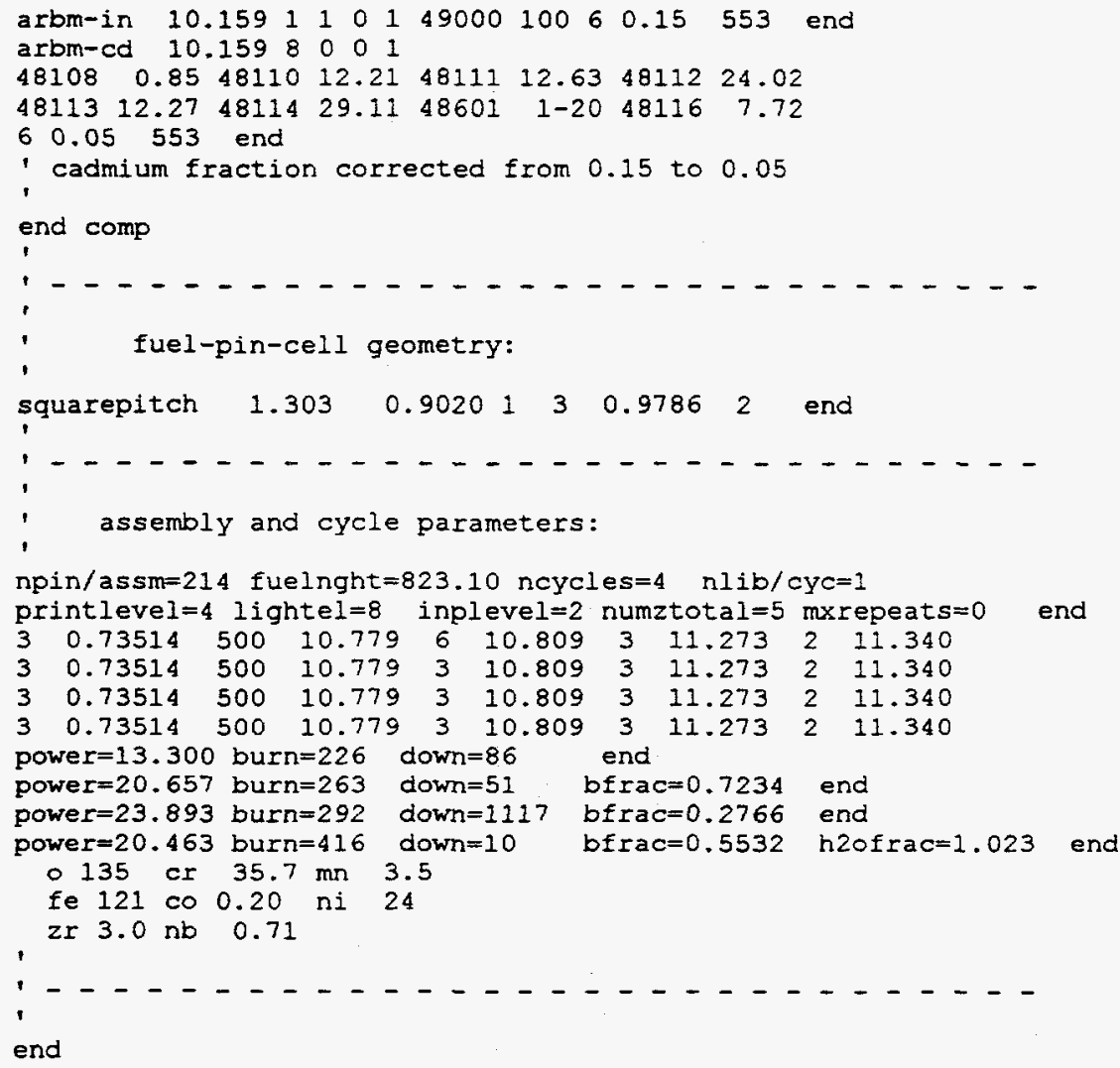




\section{Assembly 509-069. Rod L11, Axial Level 7, with a Burnup of 24.362 GWd/MTU}

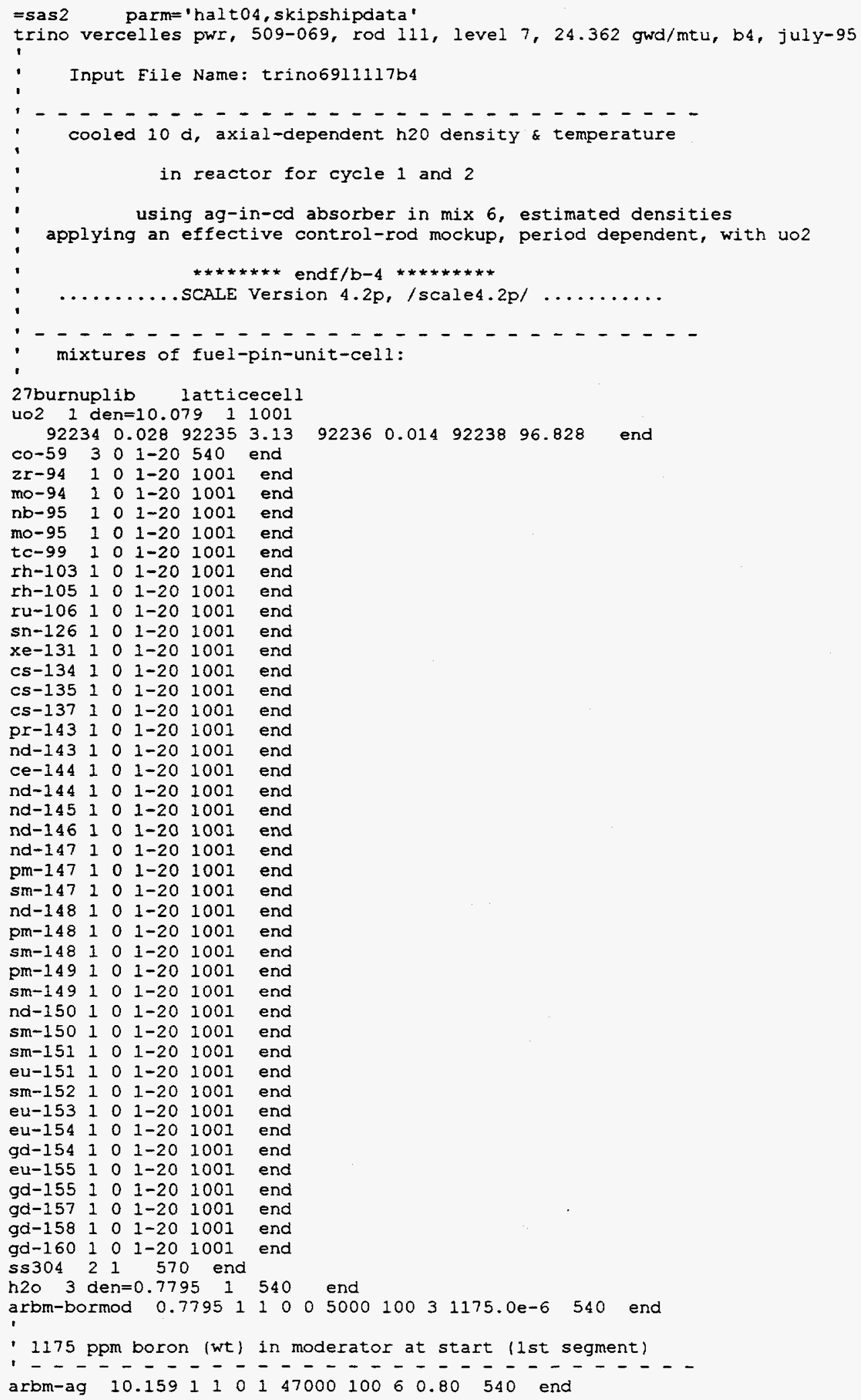




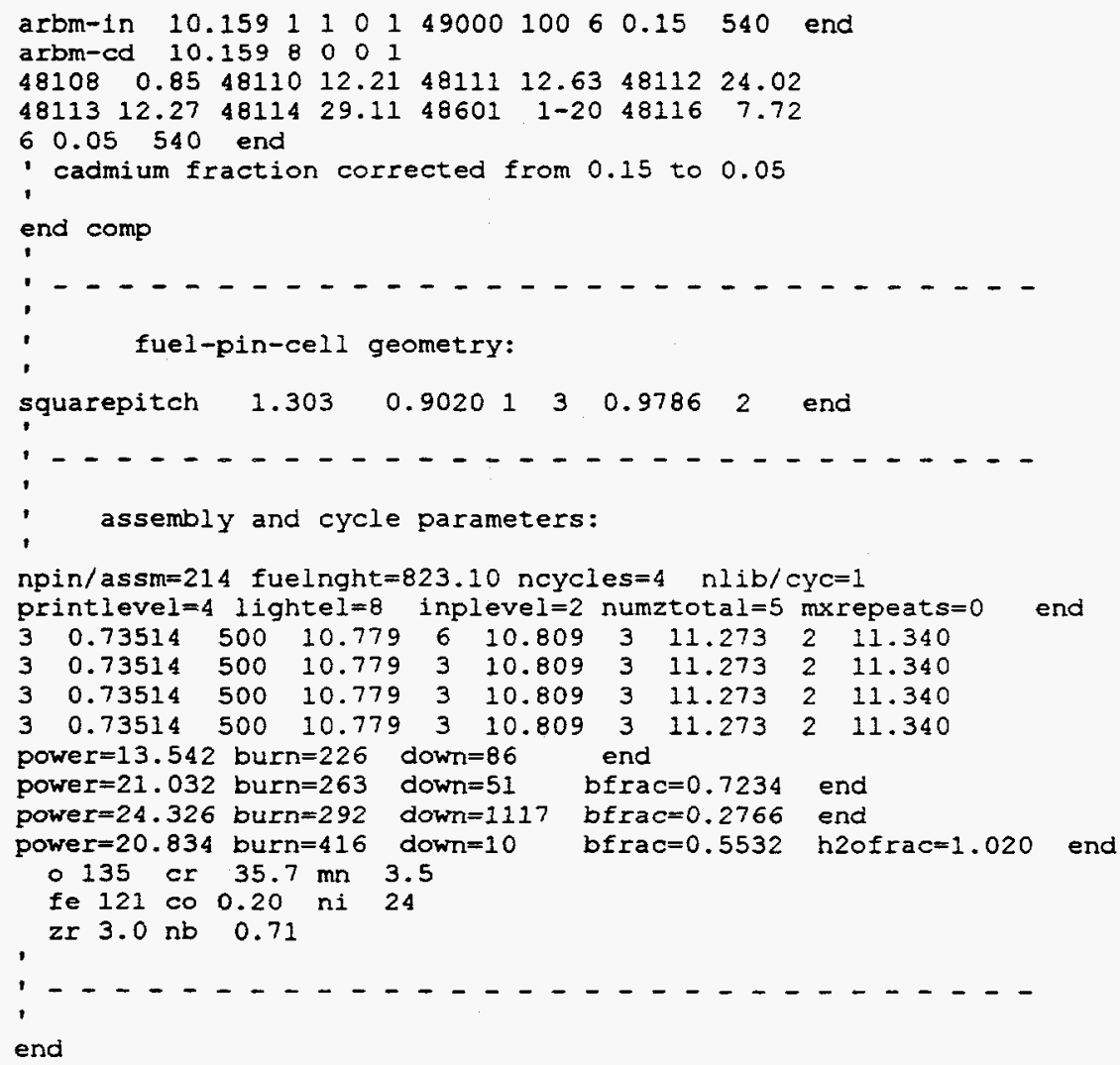




\section{Assembly 509-069, Rod L5, Axial Level 4, with a Burnup of 24.330 GWd/MTU}

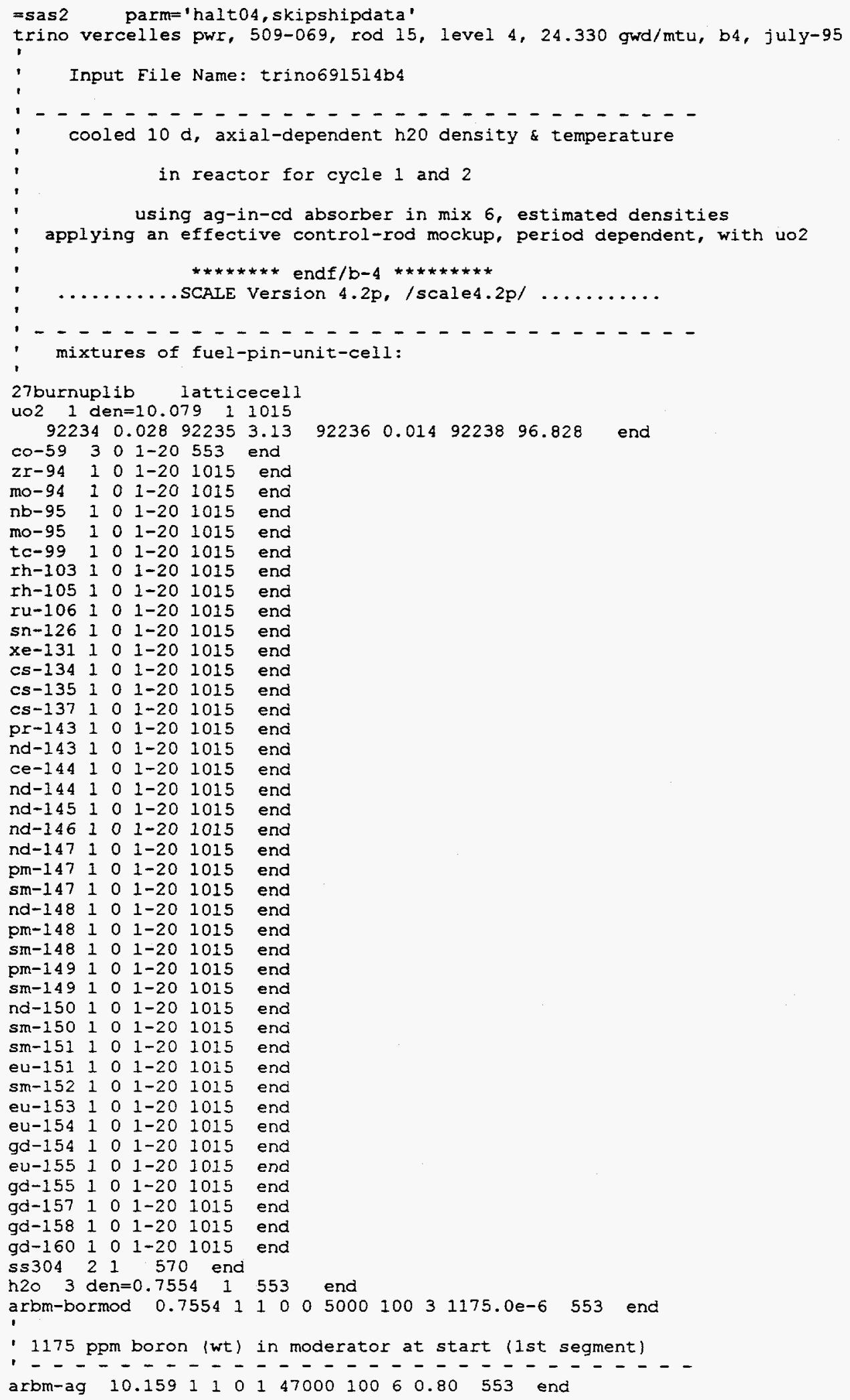




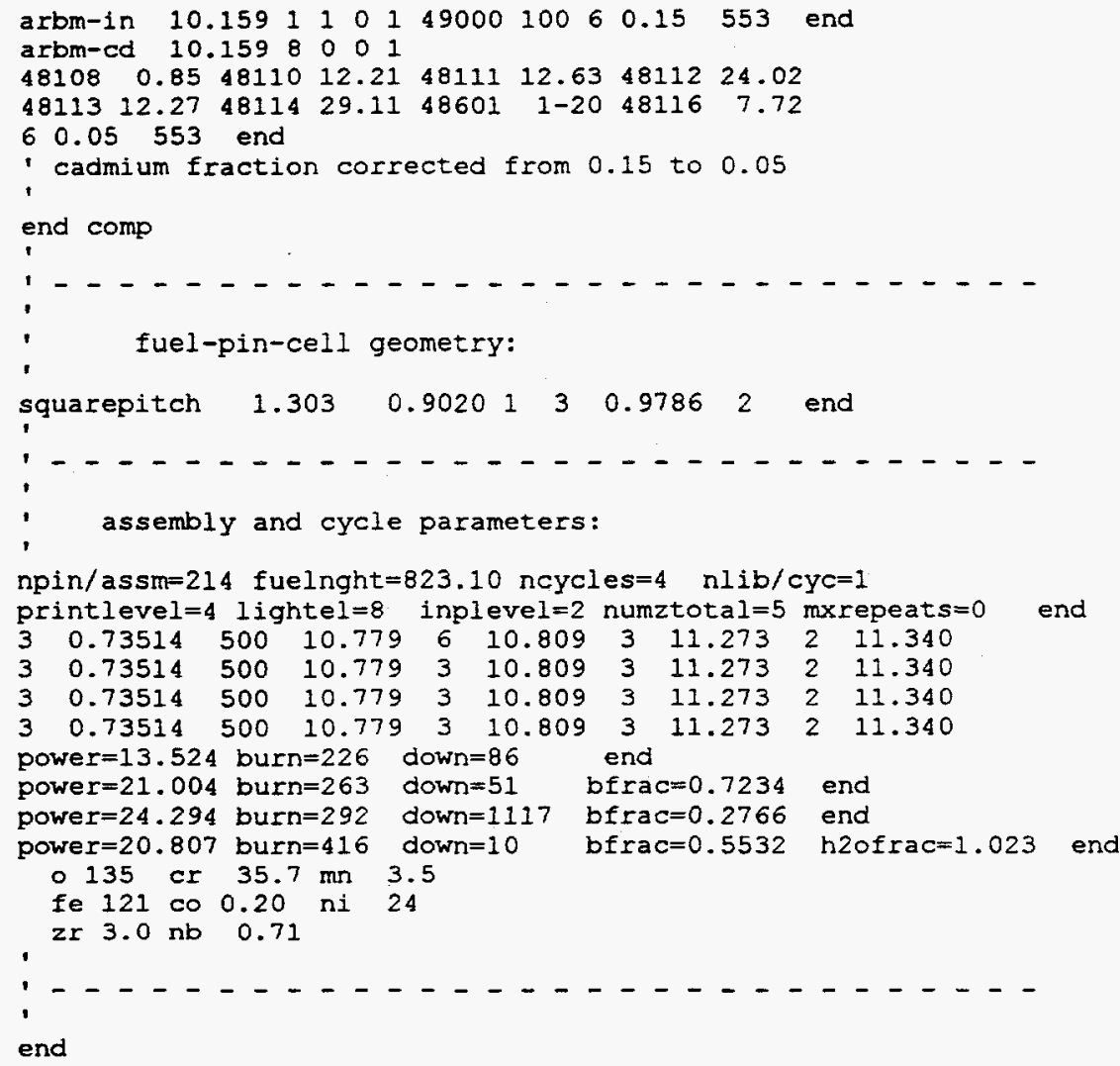




\section{Assembly 509-069, Rod L5, Axial Level 7, with a Burnup of 24.313 GWd/MTU}

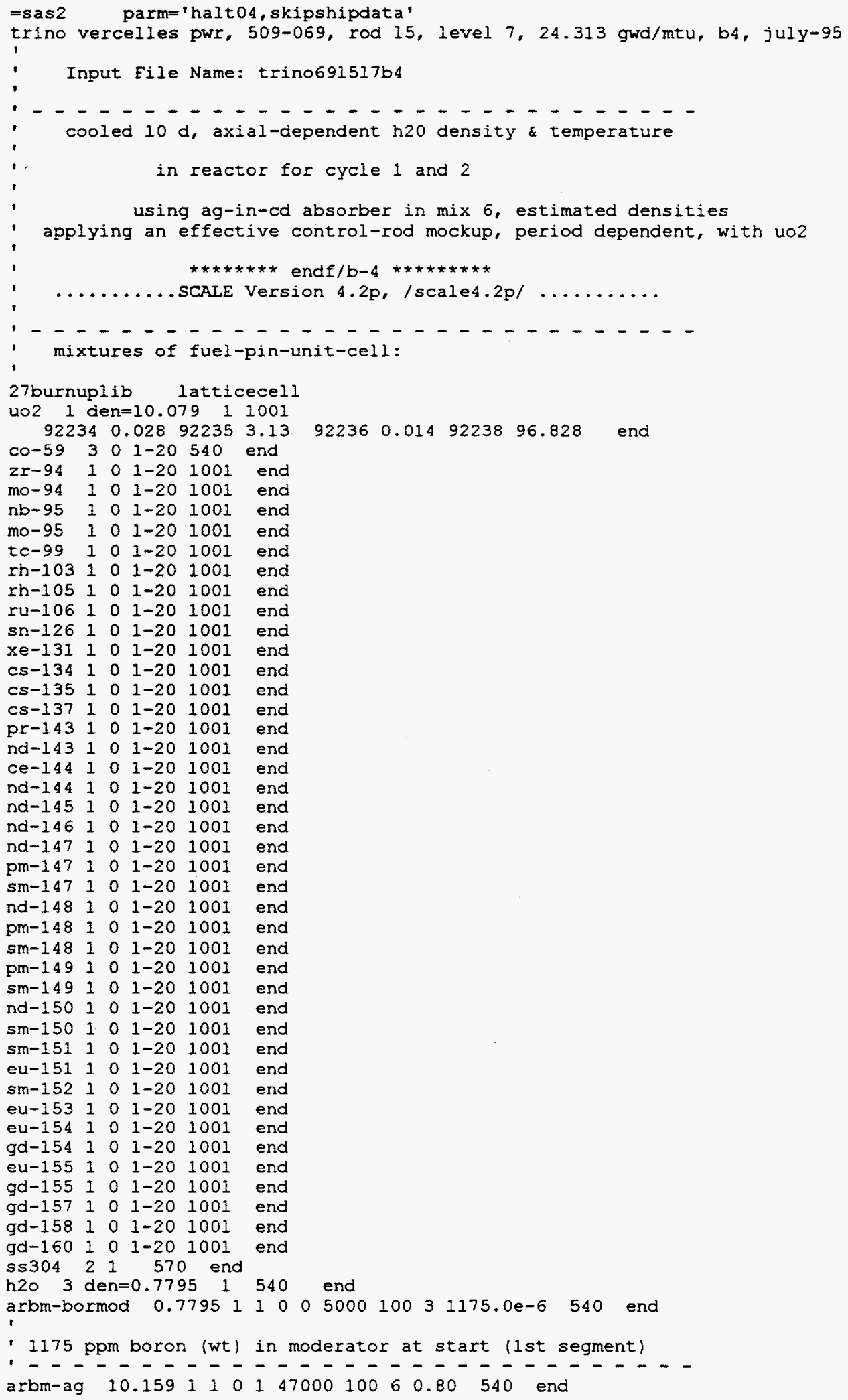




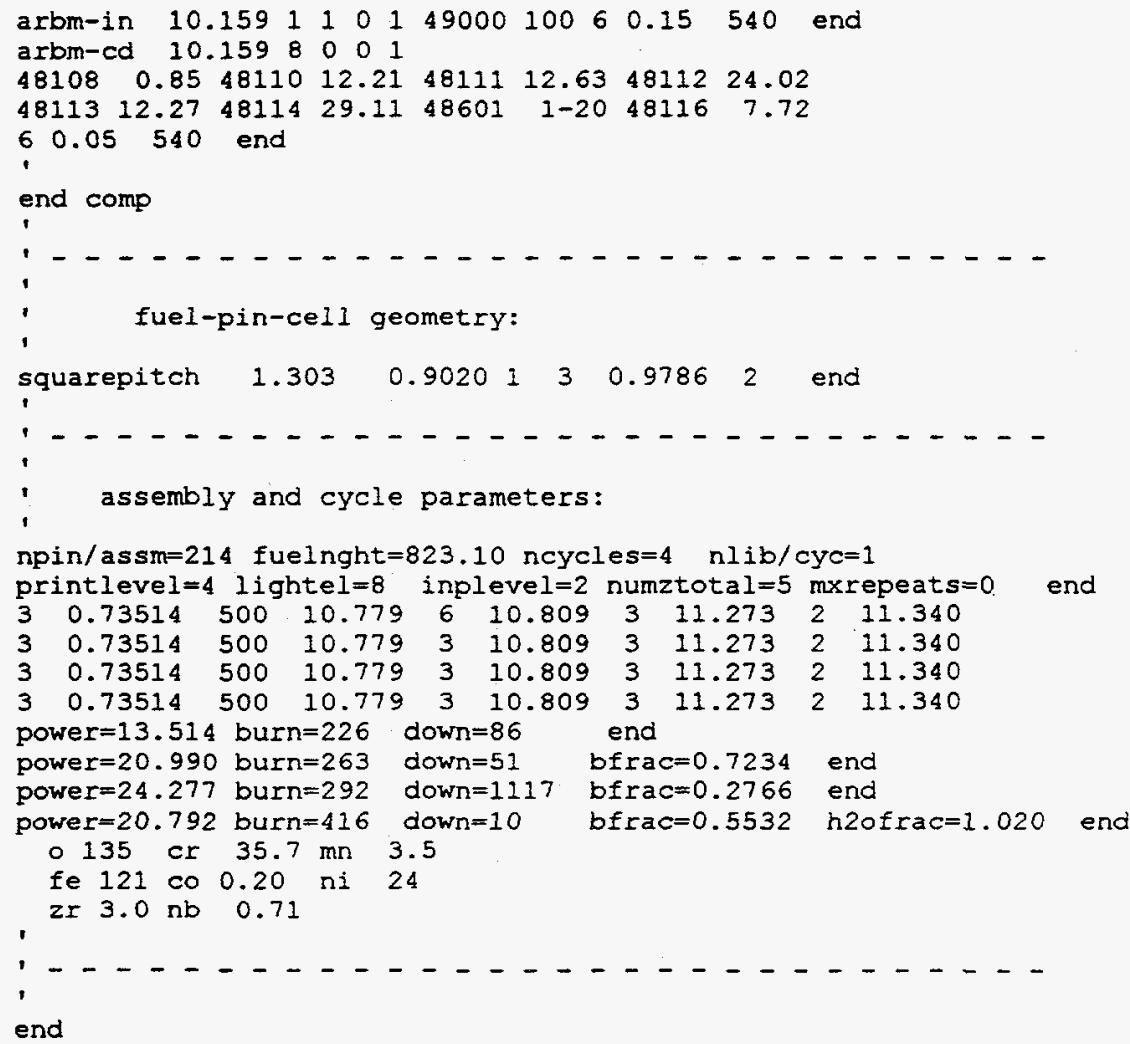




\section{APPENDIX C}

\section{SAMPLE INPUT FOR A TURKEY POINT UNIT 3 SAS2H DEPLETION CALCULATION}

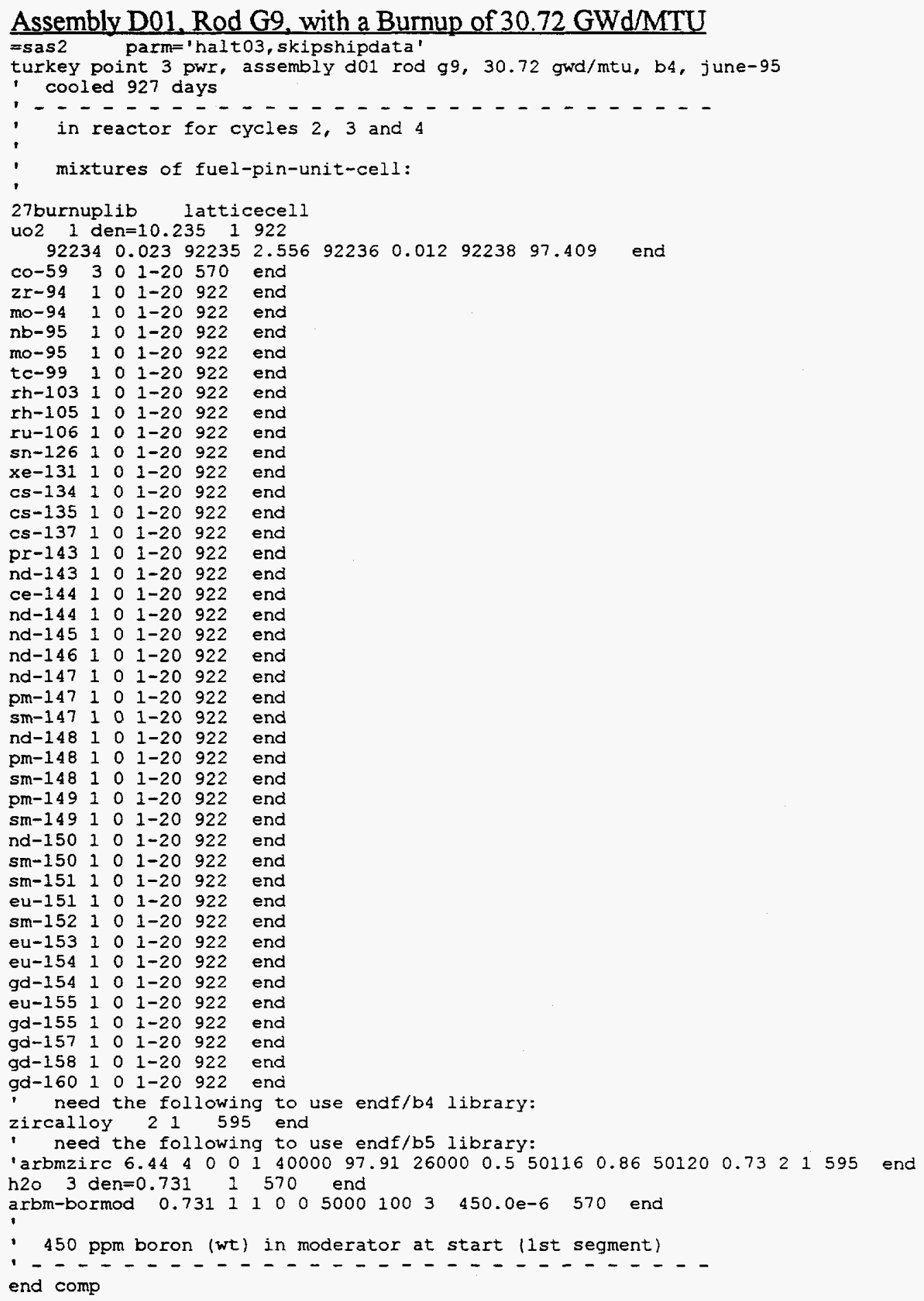




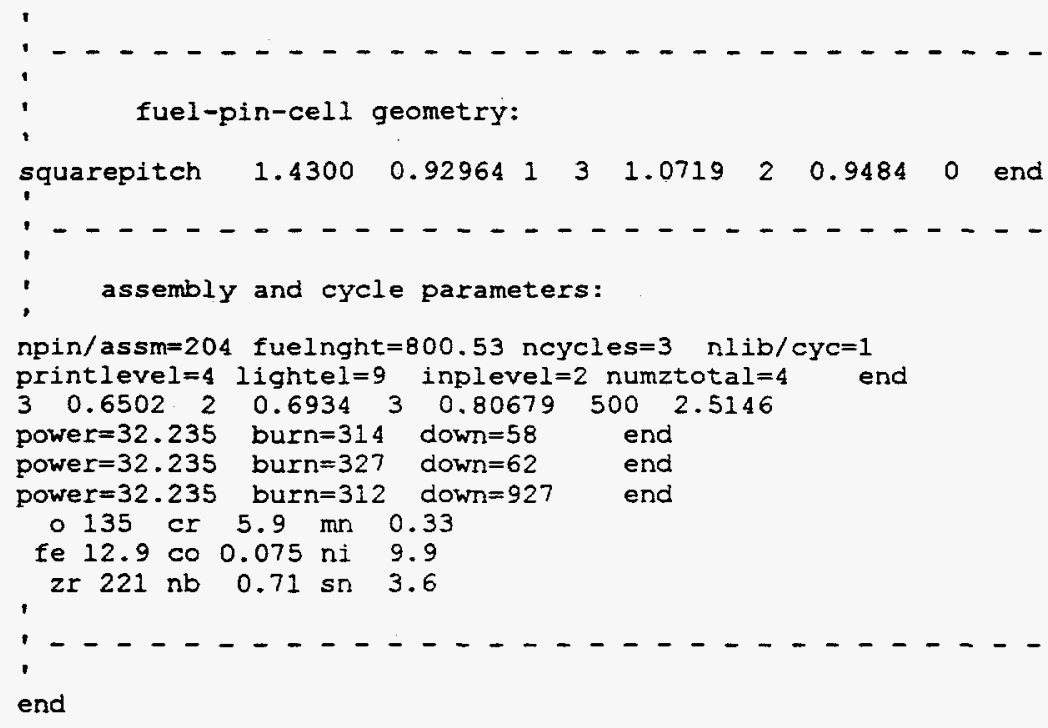




\section{Assembly D01, Rod G10, with a Burnup of $30.510 \mathrm{GWd} / \mathrm{MTU}$}

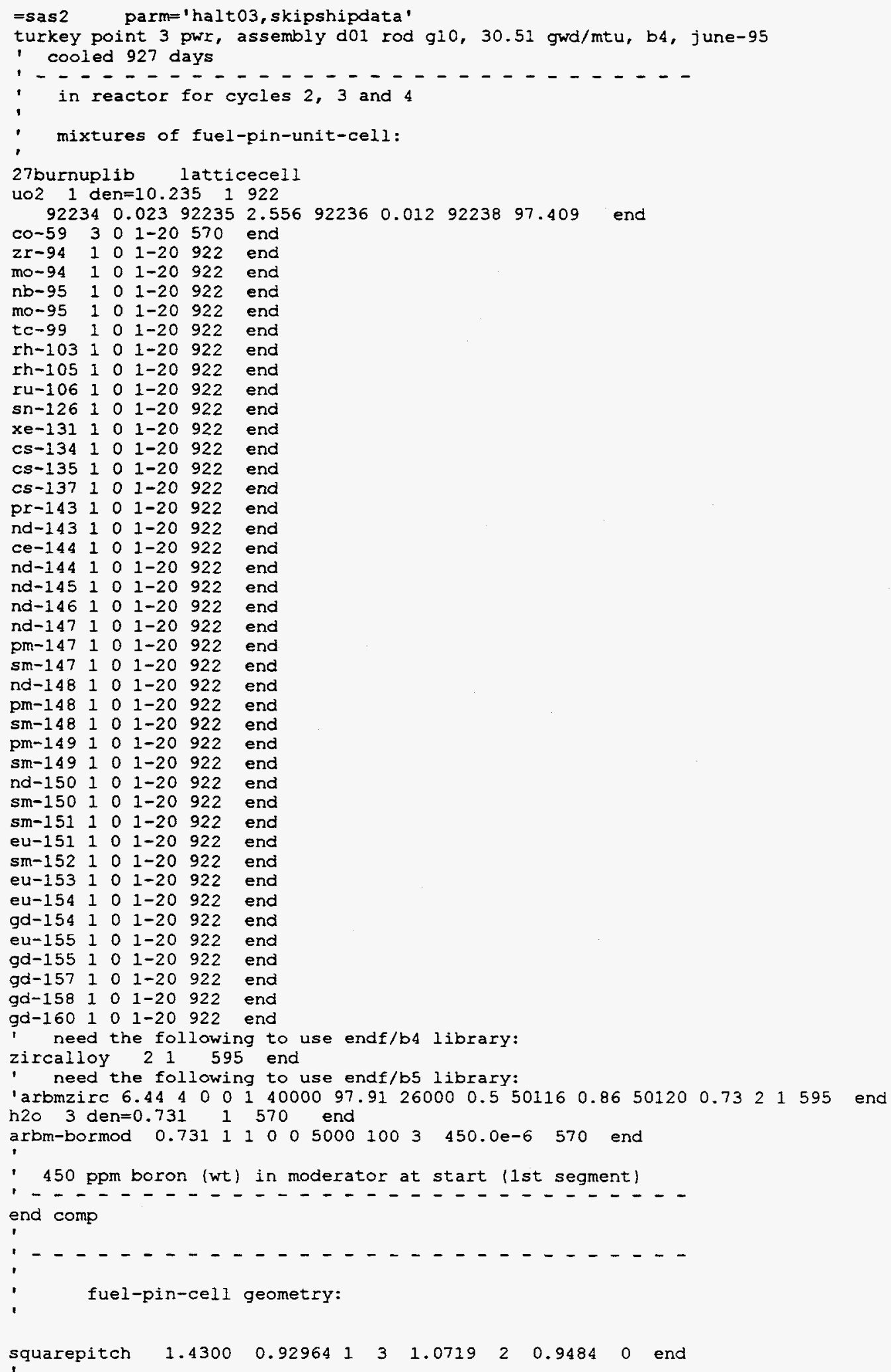


assembly and cycle parameters:

npin/assm=204 fuelnght $=800.53$ ncycles $=3$ nlib/cyc=1 printlevel $=4$ lightel $=9$ inplevel=2 numztotal $=4$ end $\begin{array}{llllllll}3 & 0.6502 & 2 & 0.6934 & 3 & 0.80679 & 500 & 2.5146\end{array}$

power $=32.015$ burn=314 down $=58$ end

power $=32.015$ burn $=327$ down $=62$ end

power $=32.015$ burn $=312$ down $=927$ end

0135 cr $5.9 \mathrm{mr} 0.33$

fe 12.9 co 0.075 ni 9.9

2r $221 \mathrm{nb} 0.71 \mathrm{sn} 3.6$

end 


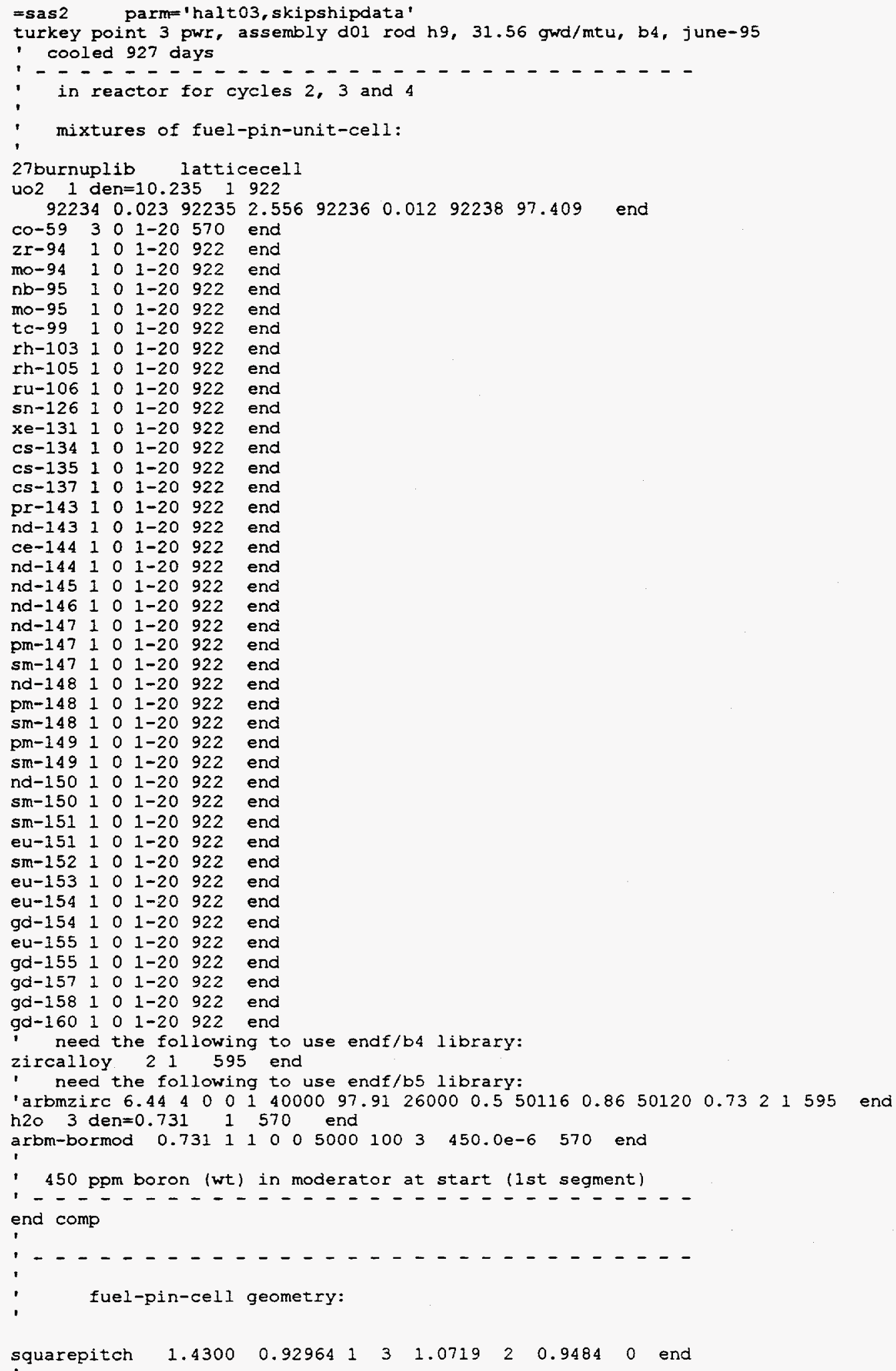


assembly and cycle parameters:

npin/assm=204 fuelnght $=800.53$ ncycles $=3$ nlib/cyc=1

printlevel=4 lightel=9 inplevel=2 numztotal=4 end

$\begin{array}{llllllll}3 & 0.6502 & 2 & 0.6934 & 3 & 0.80679 & 500 & 2.5146\end{array}$

power $=33.116$ burn=314 down $=58$ end

power $=33.116$ burn=327 down $=62$ end

power $=33.116$ burn=312 down $=927$ end

0135 cr $5.9 \mathrm{mn} 0.33$

fe 12.9 co $0.075 \mathrm{ni} 9.9$

zI $221 \mathrm{nb} 0.71 \mathrm{sn} 3.6$

end 


\section{Assembly D04, Rod G9, with a Burnup of 31.260 GWd/MTU}

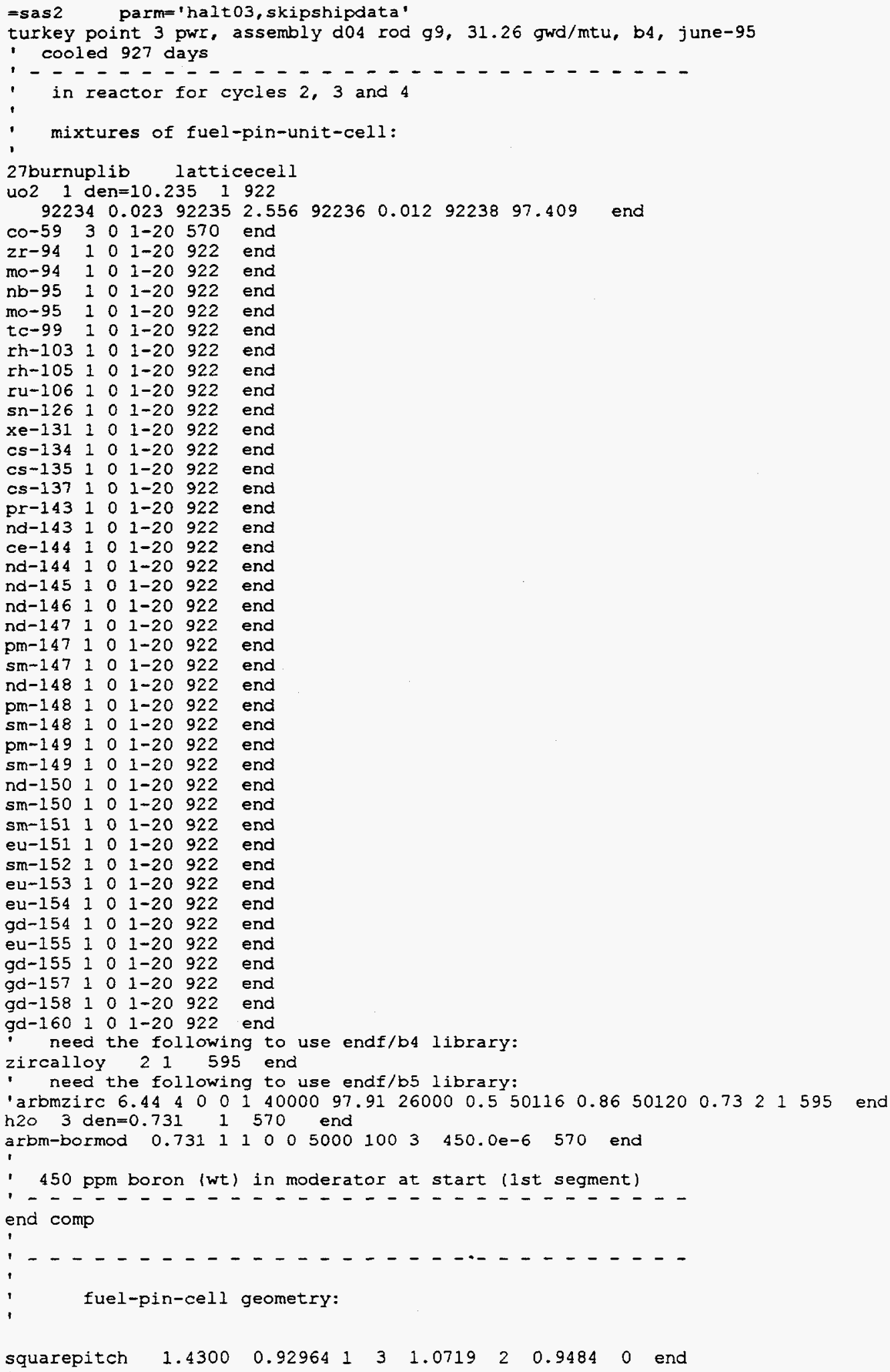




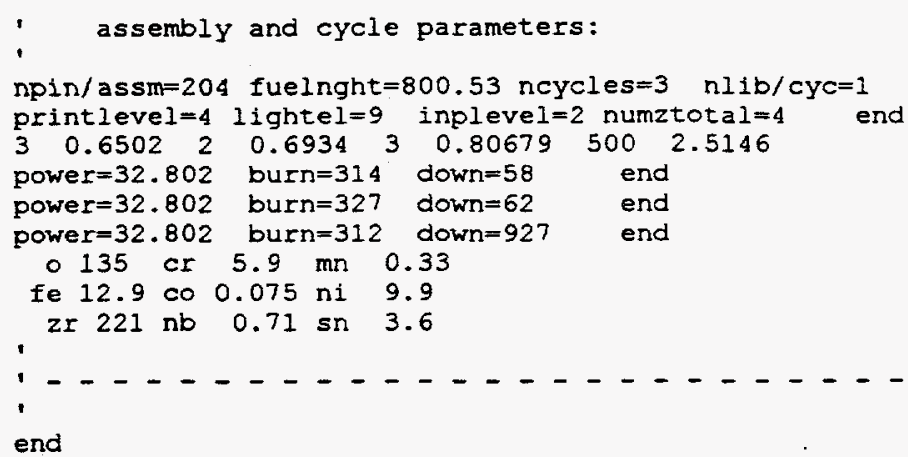




\section{Assembly D04, Rod G10, with a Burnup of $31.310 \mathrm{GWd} / \mathrm{MTU}$}

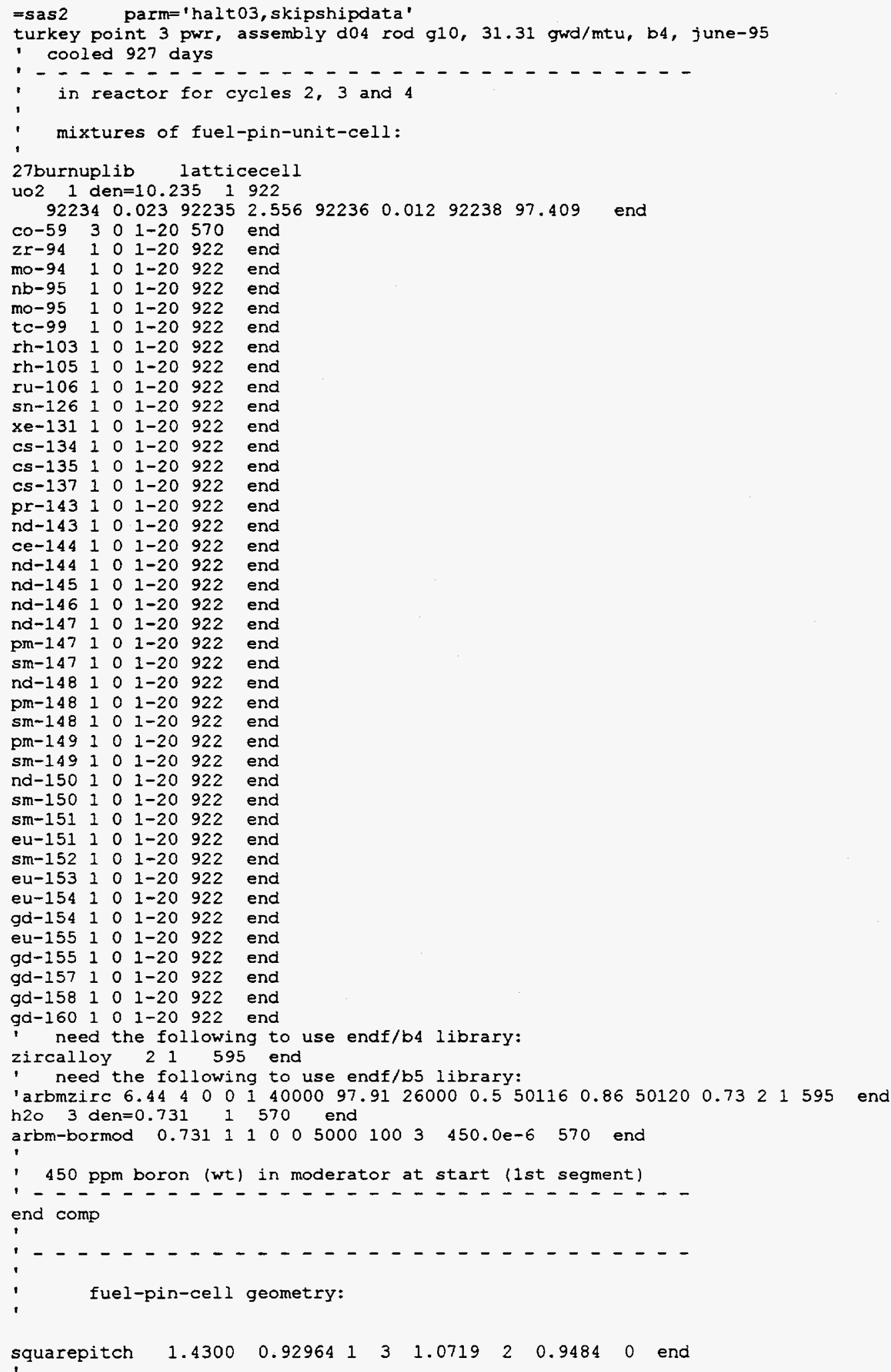


assembly and cycle parameters:

npin/assm $=204$ fuelnght $=800.53$ ncycles $=3$ nlib/cyc $=1$ printlevel $=4$ lighte $1=9$ inplevel $=2$ numztotal $=4$ end $\begin{array}{llllllll}3 & 0.6502 & 2 & 0.6934 & 3 & 0.80679 & 500 & 2.5146\end{array}$

$\begin{array}{llll}\text { power }=32.854 & \text { burn=314 } & \text { down=58 } & \text { end } \\ \text { power }=32.854 & \text { burn=327 } & \text { down }=62 & \text { end }\end{array}$

power $=32.854$ burn=312 down $=927$ end

0135 cr $5.9 \mathrm{mn} 0.33$

fe 12.9 co $0.075 \mathrm{ni} 9.9$

end 


\title{
APPENDIX D
}

\section{MEASURED AND COMPUTED ISOTOPIC CONCENTRATIONS FOR TRINO VERCELLES FUEL SAMPLES}

\author{
trino vercelles pwr \\ measured and computed irradiated fuel composition
}

fuel assembly 509-104, rod m11, level 7, 12.042 gwd/mtu

run july 1995

. compares cases using 27BURNUPLIB and 44GROUPNDF5 libraries..

nuclide, $z$ \& name measured 27BURNUPLIB sdiff 44GROUPNDF5 sdiff

units: milligrams/gram U

\begin{tabular}{|c|c|c|c|c|c|}
\hline $\mathrm{u} 235$ & $2.662 \mathrm{E}+01$ & $2.695 E+01$ & 1.281 & $2.694 \mathrm{E}+01$ & $1.28)$ \\
\hline 1236 & $2.736 E+00$ & $2.450 E+00$ & 10.481 & $2.446 E+00$ & $(-10.68)$ \\
\hline บ238 & $9.513 E+02$ & $9.519 E+02$ & 181 & $9.519 E+02$ & 18) \\
\hline pu239 & $4.586 \mathrm{E}+00$ & $4.418 E+00$ & $\left.-3.7 \frac{1}{3}\right)$ & $4.400 E+00$ & 18) \\
\hline pu240 & $7.165 \mathrm{E}-01$ & $6.665 E-01$ & -7.081 & $6.704 \mathrm{E}-01$ & $48)$ \\
\hline pu241 & $3.475 E-01$ & $3.318 E-01$ & -4.581 & $3.062 E-01$ & $(-1) \cdot 98$ \\
\hline pu242 & $3.135 \mathrm{E}-02$ & $2.534 E-02$ & $(-19.28)$ & $2.680 E-02$ & $(-14)$ \\
\hline
\end{tabular}

units: curies/gram U

$\begin{array}{lllllrlrr}44 & \text { ru106 } & 1.403 E-01 & 1.293 E-01 & (-7.88) & 1.281 E-01 & (-8.78) \\ 58 & \operatorname{ce} 144 & 5.777 E-01 & 5.626 E-01 & (-2.68) & 5.633 E-01 & (-2.58) \\ 55 & \operatorname{cs} 134 & 2.728 E-02 & 2.091 E-02 & (-23.38) & 2.018 E-02 & (-26.08) \\ 55 & \operatorname{cs} 137 & 3.895 E-02 & 3.937 E-02 & 1.18) & 3.937 E-02 & (1.18)\end{array}$

trino vercelles pwr

measured and computed irradiated fuel composition

fuel assembly 509-032, rod ell, level 4, 15.377 gwd/mtu

run july 1995

. compares cases using 27BURNUPIIB and 44GROUPNDE5 libraries..

nuclide, $z$ \& name

measured

27BURNUPLIB 8 diff

44GROUPNDF5 รdiff

units: milligrams/gram U

$\begin{array}{lrl}92 & \mathrm{u} 235 & 1.728 \mathrm{E}+01 \\ 92 & \mathrm{u} 236 & 2.834 \mathrm{E}+00 \\ 92 & \mathrm{u} 238 & 9.558 \mathrm{E}+02 \\ 94 & \text { pu239 } & 5.266 \mathrm{E}+00 \\ 94 & \text { pu240 } & 1.118 \mathrm{E}+00 \\ 94 & \text { pu241 } & 6.140 \mathrm{E}-01 \\ 94 & \text { pu242 } & 8.638 \mathrm{E}-02\end{array}$

$1.786 \mathrm{E}+01(3.48) \quad 1.795 \mathrm{E}+01(3.98)$

$2.614 \mathrm{E}+00(-7.88) \quad 2.606 \mathrm{E}+00(-8.18)$

$9.559 \mathrm{E}+02(.08) 9.560 \mathrm{E}+02(.0 \%)$

$5.201 E+00(-1.28) 4.987 E+00(-5.38)$

$1.069 \mathrm{E}+00(-4.48) \cdot 1.136 \mathrm{E}+00(1.78)$

$6.321 E-01$ (2.98) $6.055 E-01(-1.48)$

7.661 E-02 (-11.38) $8.772 \mathrm{E}-02$ ( 1.68$)$

units: curies/gram U

\begin{tabular}{lllll|r|r}
44 & ru106 & $2.118 E-01$ & $2.151 E-01$ & $1.58)$ & $2.167 E-01$ & $2.38)$ \\
58 & $\operatorname{ce} 144$ & $7.165 E-01$ & $6.886 E-01$ & $-3.98)$ & $6.877 E-01$ & $(-4.08)$ \\
55 & $\operatorname{cs} 134$ & $4.656 E-02$ & $3.748 E-02$ & $(-19.58)$ & $3.606 E-02$ & $(-22.58)$ \\
55 & $\operatorname{cs} 137$ & $4.949 E-02$ & $5.018 E-02$ & $1.48)$ & $5.018 E-02$ & $(1.48)$
\end{tabular}


trino vercelles pwr

measured and computed irradiated fuel composition

fuel assembly 509-032, rod e11, level 7, 15.898 gwd/mtu

run july 1995

. compares cases using 27BURNUPLIB and 44GROUPNDE5 libraries..

nuclide, $z$ \& name

measured

27BURNUPLIB

odiff

44GROUPNDF5 \&diff

units: milligrams/gram $U$

$\begin{array}{rrrrrrrr}92 & u 235 & 1.661 E+01 & 1.746 E+01 & (5.18) & 1.741 E+01 & (1.88) \\ 92 & u 236 & 2.739 E+00 & 2.672 E+00 & (-2.48) & 2.669 E+00 & (-2.68) \\ 92 & u 238 & 9.558 E+02 & 9.556 E+02 & (-.08) & 9.558 E+02 & (1.08) \\ 94 & \text { pu239 } & 5.234 E+00 & 5.168 E+00 & (-1.38) & 5.169 E+00 & (-1.28) \\ 94 & \text { pu240 } & 1.137 E+00 & 1.102 E+00 & (-3.18) & 1.116 E+00 & (-1.88) \\ 94 & \text { pu241 } & 6.180 E-01 & 6.530 E-01 & (5.78) & 6.044 E-01 & (-2.28) \\ 94 & \text { pu242 } & 9.487 E-02 & 8.321 E-02 & (-12.38) & 8.787 E-02(-7.48)\end{array}$

units: curies/gram U

$\begin{array}{rrrrrrrr}44 & \text { ru106 } & 2.263 E-01 & 2.240 E-01 & (-1.08) & 2.215 E-01 & (-2.18) \\ 58 & \operatorname{ce} 144 & 7.012 E-01 & 7.114 E-01 & (1.58) & 7.126 E-01 & (1.68) \\ 55 & \operatorname{cs} 134 & 4.927 E-02 & 3.948 E-02 & (-19.98) & 3.808 E-02 & (-22.78) \\ 55 & \operatorname{cs} 137 & 5.014 E-02 & 5.191 E-02 & (3.58) & 5.190 E-02 & (3.58)\end{array}$

trino vercelles pwr

measured and computed irradiated fuel composition

fuel assembly 509-032, rod e11, level 9, $11.529 \mathrm{gwd} / \mathrm{mtu}$

run july 1995

. compares cases using 27 BURNUPLIB and 44GROUPNDE5 libraries..

nuclide, $z$ \& name

measured

27BURNUPLIB

앙iff

4 4GROUPNDF5

odiff

units: milligrams/gram U

$\begin{array}{lrl}92 & \text { u235 } & 2.017 E+01 \\ 92 & \text { u236 } & 2.502 E+00 \\ 92 & \text { u238 } & 9.595 E+02 \\ 94 & \text { pu239 } & 4.418 E+00 \\ 94 & \text { pu240 } & 7.750 E-01 \\ 94 & \text { pu241 } & 3.690 E-01 \\ 94 & \text { pu242 } & 3.803 E-02\end{array}$

$2.045 E+01(1.48) \quad 2.042 E+01(1.38)$

$2.140 E+00(-14.58) \quad 2.136 E+00(-14.6 \%)$

$9.593 E+02$ ( . .08) $9.594 \mathrm{E}+02$ (. .08 $)$

$4.338 E+00(-1.88) \quad 4.330 E+00(-2.08)$

$7.436 \mathrm{E}-01(-4.08) 7.476 \mathrm{E}-01(-3.58)$

$3.684 \mathrm{E}-01$ (- -.28$) \quad 3.391 \mathrm{E}-01(-8.18)$

$3.324 E-02(-12.68) \quad 3.477 E-02(-8.6 \%)$

units: curies/gram U

$\begin{array}{lll}44 & \text { rul06 } & 1.552 E-01 \\ 58 & \operatorname{ce} 144 & 5.570 E-01 \\ 55 & \operatorname{cs} 134 & 2.711 E-02 \\ 55 & \operatorname{cs} 137 & 3.635 E-02\end{array}$

$1.389 E-01(-10.58) \quad 1.373 E-01(-11.58)$

$5.291 E-01(-5.08) 5.299 E-01(-4.98)$

$2.086 \mathrm{E}-02(-23.08) \quad 2.020 \mathrm{E}-02(-25.5 \%)$

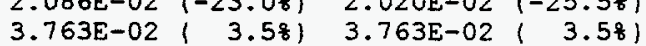


trino vercelles pwr

measured and computed irradiated fuel composition

fuel assembly 509-069, rod e11, level 1, 12.859 gwd/mtu

run july 1995

. compares cases using 27BURNUPLIB and 44GROUPNDE5 libraries..

nuclide, $z$ \& name measured 27BURNUPLIB odiff 44 GROUPNDE5 $8 d i f f$

units: milligrams/gram U

\begin{tabular}{|c|c|c|c|c|c|c|}
\hline 92 & $\begin{array}{l}4235 \\
4236\end{array}$ & $\begin{array}{l}1.946 E+01 \\
2.453 E+00\end{array}$ & $\begin{array}{l}1.949 \mathrm{E}+01 \\
2.319 \mathrm{E}+00\end{array}$ & $\left(\begin{array}{r}(-18) \\
\left(-5.4 \frac{8}{8}\right)\end{array}\right.$ & $\begin{array}{l}1.956 \mathrm{E}+01 \\
2.312 \mathrm{E}+00\end{array}$ & 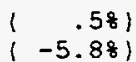 \\
\hline 92 & u238 & $9.587 \mathrm{E}+02$ & $9.581 E+02$ & -.181 & $9.582 \mathrm{E}+02$ & .087 \\
\hline 94 & pu239 & $4.580 E+00$ & $4.695 \mathrm{E}+00$ & 2.581 & $4.511 E+00$ & $\mid-1.58\}$ \\
\hline 94 & pu240 & $8.400 E-01$ & $8.540 E-01$ & 1.781 & $9.089 E-01$ & 8.281 \\
\hline 94 & pu241 & $4.000 E-01$ & $4.310 E-01$ & 7.781 & $4.145 E-01$ & 3.681 \\
\hline & pu242 & $4.600 E-02$ & $4.443 E-02$ & $-3.48)$ & $5.072 E-02$ & 10.381 \\
\hline
\end{tabular}

units: curies/gram U

$\begin{array}{rlrrrrrr}55 & \operatorname{cs} 134 & 2.494 E-02 & 1.913 E-02 & (-23.38) & 1.847 E-02 & (-25.98) \\ 55 & \operatorname{cs} 137 & 3.939 E-02 & 3.967 E-02 & (.78) & 3.967 E-02 & (1.78) \\ 63 & \text { eu154 } & 1.370 E-03 & 1.490 E-03 & 8.78) & 1.019 E-03 & (-25.68)\end{array}$

trino vercelles pwr

measured and computed irradiated fuel composition

fuel assembly 509-069, rod e11, level 2, 20.602 gwd/mtu

run july 1995

. compares cases using 27BURNUPLIB and 44GROUPNDF5 libraries..

nuclide, $z$ \& name measured 27BURNUPLIB sdiff 44GROUPNDE5 \%diff

units: milligrams/gram U

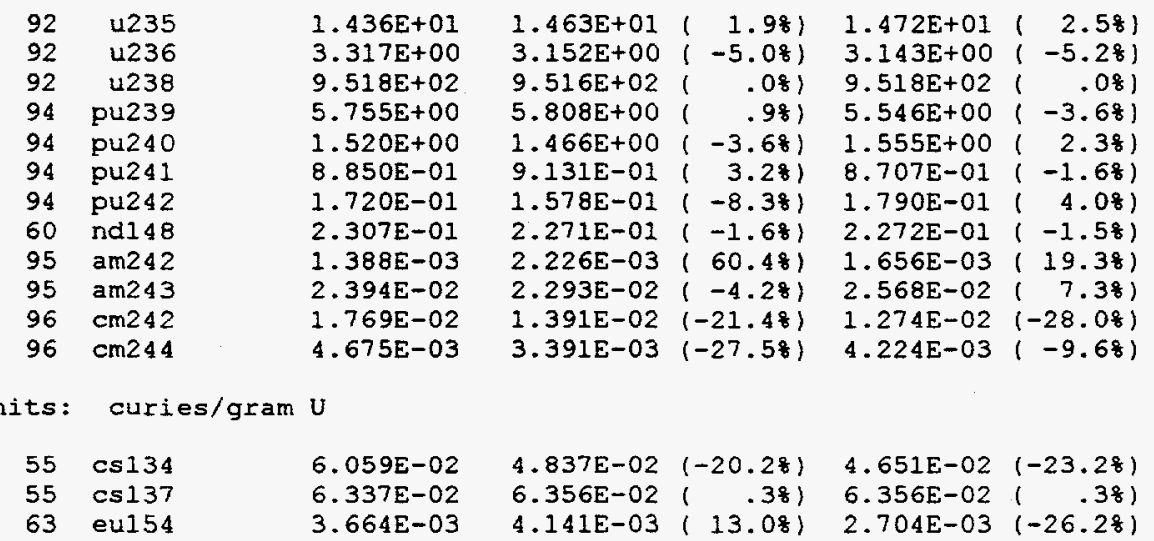


trino vercelles pwr

measured and computed irradiated fuel composition

fuel assembly 509-069, rod el1, level 4, 23.718 gwd/mtu run july 1995

. compares cases using 27BURNUPLIB and 44GROUPNDF5 libraries..

units: milligrams/gram $\mathrm{U}$

nuclide, $z$ \& name

$\begin{array}{lr}92 & u 235 \\ 92 & u 236 \\ 92 & u 238 \\ 94 & \text { pu239 } \\ 94 & \text { pu240 } \\ 94 & \text { pu241 } \\ 94 & \text { pu242 } \\ 60 & \text { nd148 } \\ 95 & \text { am242 } \\ 95 & \text { am243 } \\ 96 & \text { cm242 } \\ 96 & \text { cm244 }\end{array}$

measured

\section{1. $248 \mathrm{E}+01$}

3. $610 \mathrm{E}+0 \mathrm{O}$

9. $493 E+02$

$5.895 \mathrm{E}+00$

$1.755 \mathrm{E}+00$

1. $030 \mathrm{E}+00$

2. 435E-01

$2.655 E-01$

$2.125 E-03$

4. 533E-02

2. $435 E-02$

9.017E-03
27BURNUPLIB 8diff 44GROUPNDE5 \%diff

$$
\begin{array}{rrrr}
1.295 E+01 & (-3.88) & 1.305 E+01 & (r .58) \\
3.411 E+00 & (-5.58) & 3.403 E+00 & (-5.78) \\
9.491 E+02 & (-08) & 9.492 E+02 & (-08) \\
6.038 E+00 & (2.48) & 5.756 E+00 & (-2.48) \\
1.683 E+00 & (-4.18) & 1.784 E+00 & (-1.68) \\
1.095 E+00 & (-6.38) & 1.042 E+00 & (1.18) \\
2.227 E-01 & (-8.58) & 2.521 E-01 & (3.58) \\
2.611 E-01 & (-1.78) & 2.612 E-01 & (-1.68) \\
2.622 E-03 & (-23.48) & 1.934 E-03 & (-9.08) \\
3.715 E-02 & (-18.08) & 4.139 E-02 & (-8.78) \\
1.906 E-02 & (-21.78) & 1.750 E-02 & (-28.18) \\
6.459 E-03 & (-28.48) & 7.967 E-03 & (-11.68)
\end{array}
$$

units: curies/gram U

$\begin{array}{rlrrrrr}55 & \operatorname{cs} 134 & 7.605 E-02 & 6.326 E-02 & (-16.88) & 6.078 E-02 & (-20.18) \\ 55 & \operatorname{cs} 137 & 7.242 E-02 & 7.318 E-02 & (1.18) & 7.317 E-02 & (1.08) \\ 63 & \text { eu154 } & 4.643 E-03 & 5.524 E-03 & (19.08) & 3.538 E-03 & (-23.88)\end{array}$


trino vercelles pwr

measured and computed irradiated fuel composition

fuel assembly 509-069, rod e11, level 7, 24.304 gwd/mtu

run july 1995

. compares cases using 27BURNUPLIB and 44GROUPNDE5 libraries..

nuclide, $z$ \& name measured 27BURNUPLIB gdiff 44GROURNDE5 \&diff

units: milligrams/gram U

\begin{tabular}{|c|c|c|c|c|c|c|}
\hline 92 & u235 & $1.235 E+01$ & $1.255 \mathrm{E}+01$ & 1.781 & $1.247 E+01$ & 1.081 \\
\hline 92 & $\mathrm{u} 236$ & $3.638 \mathrm{E}+00$ & $3.459 E+00$ & -4.981 & $3.456 E+00$ & $(-5.08)$ \\
\hline 92 & u238 & $9.492 E+02$ & $9.488 \mathrm{E}+02$ & $.08)$ & $9.490 \mathrm{E}+02$ & .081 \\
\hline 94 & pu239 & $6.070 \mathrm{E}+00$ & $5.941 E+00$ & $(-2.1$ 웅 $)$ & $5.965 E+00$ & $\left(-1.7 \frac{8}{8}\right)$ \\
\hline 94 & pu240 & $1.825 \mathrm{E}+00$ & $1.711 E+00$ & $(-6.28)$ & $1.744 \mathrm{E}+00$ & -4.481 \\
\hline 94 & pu241 & $1.060 E+00$ & $1.108 E+00$ & $\left.4.5 \frac{8}{8}\right)$ & $1.034 \mathrm{E}+00$ & $(-2.58)$ \\
\hline 94 & pu 242 & $2.575 \mathrm{E}-01$ & $2.357 \mathrm{E}-01$ & $(-8.58)$ & $2.499 \mathrm{E}-01$ & $(-2.98)$ \\
\hline 60 & ndl 48 & $2.719 E-01$ & $2.676 \mathrm{E}-01$ & $(-1.68)$ & $2.677 E-01$ & $(-1.58)$ \\
\hline 95 & $\operatorname{am} 242$ & $2.257 \mathrm{E}-03$ & $2.602 \mathrm{E}-03$ & $15.38)$ & $1.820 E-03$ & $(-19.48)$ \\
\hline 9 & $\operatorname{am} 243$ & $4.584 \mathrm{E}-02$ & $3.968 \mathrm{E}-02$ & $(-13.48)$ & 4. $112 \mathrm{E}-02$ & $1-10.38$ \\
\hline 96 & $\operatorname{cm} 242$ & $2.664 \mathrm{E}-02$ & $1.977 \mathrm{E}-02$ & $(-25.88)$ & $1.719 \mathrm{E}-02$ & $(-35.58)$ \\
\hline 96 & $\operatorname{cm} 244$ & $9.904 \mathrm{E}-03$ & $7.015 \mathrm{E}-03$ & $(-29.28)$ & $7.982 E-03$ & $1-19.4 \frac{8}{8}$ \\
\hline
\end{tabular}

units: curies/gram U

$\begin{array}{rlrrrrr}55 & \operatorname{cs} 134 & 7.793 \mathrm{E}-02 & 6.573 \mathrm{E}-02 & (-15.78) & 6.335 \mathrm{E}-02 & (-18.78) \\ 55 & \operatorname{cs} 137 & 7.352 \mathrm{E}-02 & 7.502 \mathrm{E}-02 & (2.08) & 7.500 \mathrm{E}-02 & 2.08) \\ 63 & \text { eu154 } & 4.305 \mathrm{E}-03 & 5.753 \mathrm{E}-03 & (33.68) & 3.753 \mathrm{E}-03 & (-12.88)\end{array}$


trino vercelles pwr

measured and computed irradiated fuel composition

fuel assembly 509-069, rod e5, level 4, 23.867 gwd/mtu

run july 1995

.. compares cases using 27BURNUPLIB and 44GROUPNDF5 libraries..

\begin{tabular}{|c|c|c|c|c|c|c|}
\hline huclide, & $z \&$ name & measured & 27 BURNUPLIB & sdiff & 44 GROUPNDF5 & $8 \operatorname{diff}$ \\
\hline units & \multicolumn{6}{|c|}{ milligrams/gram $U$} \\
\hline 92 & $\llcorner 235$ & $1.291 E+01$ & 1. $288 E+01$ & -.281 & 1. $297 \mathrm{E}+01$ & 581 \\
\hline 92 & $\mathrm{u} 236$ & $3.520 E+00$ & $3.423 \mathrm{E}+00$ & $(-2.88)$ & $3.415 E+00$ & $(-3.08)$ \\
\hline 92 & u238 & $9.492 E+02$ & $9.489 \mathrm{E}+02$ & .081 & $9.491 E+02$ & $.08)$ \\
\hline 94 & pu239 & $5.950 E+00$ & $6.050 \mathrm{E}+00$ & 1.781 & $5.766 E+00$ & $(-3.18)$ \\
\hline 94 & pu240 & $1.760 \mathrm{E}+00$ & 1. $693 \mathrm{E}+00$ & $(-3.88)$ & $1.794 E+00$ & 1.981 \\
\hline 94 & pu241 & $1.050 \mathrm{E}+00$ & $1.104 \mathrm{E}+00$ & $(5.18)$ & 1. $050 \mathrm{E}+00$ & $.08)$ \\
\hline 94 & pu242 & $2.400 \mathrm{E}-01$ & $2.261 E-01$ & $(-5.88)$ & $2.559 \mathrm{E}-01$ & $\left.6.6 \frac{8}{1}\right)$ \\
\hline 60 & nd 148 & $2.666 \mathrm{E}-01$ & $2.627 \mathrm{E}-01$ & $(-1.58)$ & $2.628 \mathrm{E}-01$ & $(-1.48)$ \\
\hline 96 & $\operatorname{cm} 242$ & $2.318 \mathrm{E}-02$ & 1. $933 E-02$ & $(-16.68)$ & $1.775 \mathrm{E}-02$ & $(-23.48)$ \\
\hline 96 & $\operatorname{cm} 244$ & $8.960 E-03$ & $6.650 E-03$ & $(-25.88)$ & $8.200 E-03$ & $(-8.5 \%)$ \\
\hline
\end{tabular}

units: curies/gram U

$\begin{array}{rlrrrrr}55 & \operatorname{cs} 134 & 1.028 E-01 & 6.404 E-02 & (-37.78) & 6.152 E-02 & (-40.28) \\ 55 & \operatorname{cs} 137 & 7.277 E-02 & 7.364 E-02 & 1.28) & 7.363 E-02 & (1.28) \\ 63 & \text { eu154 } & 4.607 E-03 & 5.596 E-03 & 21.58) & 3.582 E-03 & (-22.38)\end{array}$


trino verceiles pwr

measured and computed irradiated fuel composition

fuel assembly 509-069, rod e5, level 7, 24.548 gwd/mtu

run july 1995

. compares cases using 27BURNUPLIB and 44GROUPNDF5 libraries..

nuclide, $z \&$ name measured 27BURNUPLIB \&diff 44GROUPNDF5 \&diff

units: milligrams/gram U

\begin{tabular}{|c|c|c|c|c|c|c|}
\hline 92 & u235 & $1.221 \mathrm{E}+01$ & $1.243 E+01$ & 1.881 & $1.235 \mathrm{E}+01$ & $1.1 \%)$ \\
\hline 92 & u236 & $3.54 O E+00$ & $3.477 \mathrm{E}+00$ & $(-1.8 \%)$ & $3.474 \mathrm{E}+00$ & -1.981 \\
\hline 92 & $\mathrm{u} 238$ & $9.483 E+02$ & $9.486 E+02$ & .081 & $9.488 E+02$ & .081 \\
\hline 94 & pu239 & $5.980 \mathrm{E}+00$ & $5.958 E+00$ & -.481 & $5.983 E+00$ & $.0 \% 1$ \\
\hline 94 & pu240 & $1.785 \mathrm{E}+00$ & $1.727 \mathrm{E}+00$ & $(-3.28)$ & $1.761 E+00$ & -1 \\
\hline 94 & pu241 & $1.055 \mathrm{E}+00$ & $1.122 \mathrm{E}+00$ & 6.481 & $1.047 E+00$ & -.881 \\
\hline 94 & pu242 & $2.54 O E-01$ & $2.414 \mathrm{E}-01$ & $(-5.08)$ & $2.560 E-01$ & $.8 \% 1$ \\
\hline 60 & nd1 48 & $2.740 \mathrm{OE}-01$ & $2.702 E-01$ & $(-1.48)$ & $2.704 E-01$ & $-1.38)$ \\
\hline 95 & $\operatorname{am} 242$ & $2.440 \mathrm{E}-03$ & $2.630 \mathrm{E}-03$ & 7.881 & $1.840 E-03$ & $(-24.68)$ \\
\hline 95 & $\operatorname{am} 243$ & $4.615 E-02$ & $4.107 E-02$ & $(-11.08)$ & $4.255 E-02$ & $-7.8 \% 1$ \\
\hline 96 & $\operatorname{cm} 242$ & $2.512 \mathrm{E}-02$ & $2.021 \mathrm{E}-02$ & $(-19.58)$ & $1.758 \mathrm{E}-02$ & $\left(-30.0 \frac{0}{6}\right)$ \\
\hline 96 & $\mathrm{~cm} 244$ & $9.422 \mathrm{E}-03$ & $7.350 \mathrm{E}-03$ & $(-22.08)$ & $8.361 E-03$ & $(-11,38)$ \\
\hline
\end{tabular}

units: curies/gram U

$\begin{array}{rlrllll}55 & \operatorname{cs} 134 & 7.959 E-02 & 6.703 E-02 & (-15.88) & 6.460 \mathrm{E}-02 & (-18.88) \\ 55 & \operatorname{cs} 137 & 7.581 \mathrm{E}-02 & 7.577 \mathrm{E}-02 & (-.18) & 7.576 \mathrm{E}-02 & (-.18) \\ 63 & \text { eu154 } & 5.001 \mathrm{E}-03 & 5.872 \mathrm{E}-03 & (17.48) & 3.827 \mathrm{E}-03 & (-23.58)\end{array}$

trino vercelles pwr

measured and computed irradiated fuel composition

fuel assembly 509-069, rod 111, level 4, 23.928 gwd/mtu

run july 1995

. compares cases using 27BURNUPLIB and 44GROUPNDF5 libraries..

nuclide, $z$ \& name measured 27BURNUPLIB \&diff 44GROUPNDF5 \&diff

units: milligrams/gram U

\begin{tabular}{|c|c|c|c|c|c|c|}
\hline 92 & $\mathrm{u} 235$ & $1.282 \mathrm{E}+01$ & $1.285 \mathrm{E}+01$ & $.28)$ & 1. $294 \mathrm{E}+01$ & 1.081 \\
\hline 92 & $u 236$ & $3.753 E+00$ & $3.428 \mathrm{E}+00$ & $(-8.78)$ & $3.419 E+00$ & $(-8.98)$ \\
\hline 92 & 4238 & $9.485 E+02$ & $9.489 E+02$ & .087 & $9.490 E+02$ & .181 \\
\hline 94 & pu239 & $6.060 E+00$ & $6.054 \mathrm{E}+00$ & -.181 & $5.771 E+00$ & $(-4.8 \div)$ \\
\hline 94 & pu240 & $1.790 E+00$ & $1.697 \mathrm{E}+00$ & $(-5.28)$ & $1.799 \mathrm{E}+00$ & .581 \\
\hline 94 & pu241 & $1.050 E+00$ & $1.108 \mathrm{E}+00$ & $5.5 \%\}$ & $1.053 E+00$ & .381 \\
\hline 94 & pu242 & $2.470 E-01$ & $2.275 \mathrm{E}-01$ & $\{-7.98\}$ & $2.575 \mathrm{E}-01$ & 4.281 \\
\hline 60 & nd1 48 & $2.676 E-01$ & $2.634 \mathrm{E}-01$ & $(-1.68)$ & 2. $635 \mathrm{E}-01$ & $(-1.58)$ \\
\hline 95 & $\operatorname{am} 242$ & $1.962 \mathrm{E}-03$ & $2.648 \mathrm{E}-03$ & $(35.08)$ & $1.952 \mathrm{E}-03$ & -.58 \\
\hline 95 & $\operatorname{am} 243$ & $4.452 E-02$ & $3.829 E-02$ & $\{-14.08\}$ & $4.265 \mathrm{E}-02$ & $(-4.28)$ \\
\hline 96 & $\operatorname{cm} 242$ & $2.796 \mathrm{E}-02$ & $1.944 \mathrm{E}-02$ & $(-30.58)$ & $1.785 E-02$ & $(-36.28)$ \\
\hline 96 & $\operatorname{cm} 244$ & $9.155 \mathrm{E}-03$ & $6.729 E-03$ & $(-26.58)$ & $8.296 \mathrm{E}-03$ & $1-9.48$ \\
\hline
\end{tabular}


trino vercelles pwr

measured and computed irradiated fuel composition

fuel assembly 509-069, rod 111, level 7, 24.362 gwd/mtu

run july 1995

. compares cases using 27BURNUPIIB and 44GROUPNDF5 libraries..

nuclide, $z$ \&ame

measured

27BURNUPIIB 8diff 44GROUPNDF5 8diff

units: milligrams/gram U

\begin{tabular}{|c|c|c|c|c|c|c|}
\hline 92 & u235 & $1.225 E+01$ & $1.253 E+01$ & 2.281 & 1. $244 \mathrm{E}+01$ & 1.581 \\
\hline 92 & $\mathrm{u} 236$ & $3.465 E+00$ & $3.463 E+00$ & $-.18)$ & $3.460 E+00$ & -.181 \\
\hline 92 & u238 & $9.482 \mathrm{E}+02$ & $9.488 E+02$ & $.18)$ & $9.489 \mathrm{E}+02$ & $.18)$ \\
\hline 94 & pu239 & $5.995 E+00$ & $5.945 E+00$ & -.881 & $5.969 E+00$ & -.481 \\
\hline 94 & pu240 & $1.810 E+00$ & $1.715 E+00$ & $(-5.38)$ & $1.748 E+00$ & $(-3.48)$ \\
\hline 94 & pu241 & $1.055 \mathrm{E}+00$ & $1.111 E+00$ & 5.381 & $1.037 \mathrm{E}+00$ & $(-1.78)$ \\
\hline 94 & pu 242 & $2.590 \mathrm{E}-01$ & $2.371 E-01$ & $(-8.58)$ & $2.514 \mathrm{E}-01$ & $(-2.98)$ \\
\hline 60 & nd 148 & $2.722 E-01$ & $2.682 E-01$ & $(-1.58)$ & $2.683 E-01$ & $(-1.48)$ \\
\hline 95 & $\operatorname{am} 242$ & $2.191 E-03$ & $2.609 E-03$ & $(19.18)$ & $1.825 \mathrm{E}-03$ & $(-16.7 \%)$ \\
\hline 95 & $\operatorname{am} 243$ & $4.247 \mathrm{E}-02$ & $4.001 E-02$ & $(-5.8 \%)$ & $4.146 E-02$ & $(-2.48)$ \\
\hline 96 & $\mathrm{~cm} 242$ & $2.466 \mathrm{E}-02$ & 1. $988 \mathrm{E}-02$ & $(-19.48)$ & 1. $728 E-02$ & $(-29.98)$ \\
\hline 96 & $\operatorname{cm} 244$ & $9.734 E-03$ & $7.094 E-03$ & $(-27.18)$ & $8.071 E-03$ & $(-17.18)$ \\
\hline
\end{tabular}

units: curies/gram U
$55 \operatorname{cs} 134$
$55 \operatorname{cs} 137$
7. $942 \mathrm{E}-02$
7. $507 \mathrm{E}-02$
$6.604 \mathrm{E}-02(-16.98) \quad 6.365 \mathrm{E}-02(-19.98)$
63 eu154
4. $477 \mathrm{E}-03$
7. 519E-02
.28) $7.518 \mathrm{E}-02$
.28
$5.781 \mathrm{E}-03(29.18) \quad 3.770 \mathrm{E}-03(-15.88)$ 
trino vercelles pwr

measured and computed irradiated fuel composition

fuel assembly 509-069, rod 15, level 4, 24.330 gwd/mtu

run july 1995

. compares cases using 27BURNUPLIB and 44GROUPNDF5 libraries..

nuclide, $z$ \& name measured 27BURNUPLIB sdiff 44GROUPNDF5 sdiff

units: milligrams/gram U

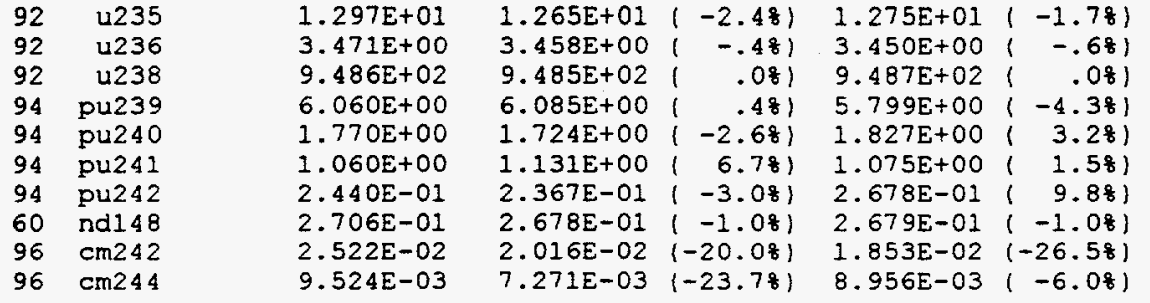

units: curies/gram U

$\begin{array}{rlrrrrr}55 & \operatorname{cs} 134 & 7.667 E-02 & 6.649 E-02 & (-13.38) & 6.387 E-02 & (-16.78) \\ 55 & \operatorname{cs} 137 & 7.360 E-02 & 7.507 E-02 & 2.08) & 7.506 E-02 & (2.08) \\ 63 & \text { eu154 } & 4.612 E-03 & 5.822 E-03 & 26.28) & 3.719 E-03 & (-19.48)\end{array}$

trino verceiles pwr

measured and computed irradiated fuel composition

fuel assembly 509-069, rod 15, level 7, 24.313 gwd/mtu

run july 1995

. compares cases using 27BURNUPIIB and 44GROUPNDFS 1ibraries..

nuclide, $z$ \& name

measured

27BURNUPLIB

odiff

4 4GROUPNDF5

idiff

units: milligrams/gram U

$\begin{array}{lrl}92 & \mathrm{u} 235 & 1.231 \mathrm{E}+01 \\ 92 & \mathrm{u} 236 & 3.569 \mathrm{E}+00 \\ 92 & \mathrm{u} 238 & 9.472 \mathrm{E}+02 \\ 94 & \text { pu239 } & 5.970 \mathrm{E}+00 \\ 94 & \text { pu240 } & 1.790 \mathrm{E}+00 \\ 94 & \text { pu241 } & 1.060 \mathrm{E}+00 \\ 94 & \text { pu242 } & 2.500 \mathrm{E}-01 \\ 96 & \mathrm{~cm} 242 & 2.481 \mathrm{E}-02 \\ 96 & \mathrm{~cm} 244 & 8.786 \mathrm{E}-03\end{array}$

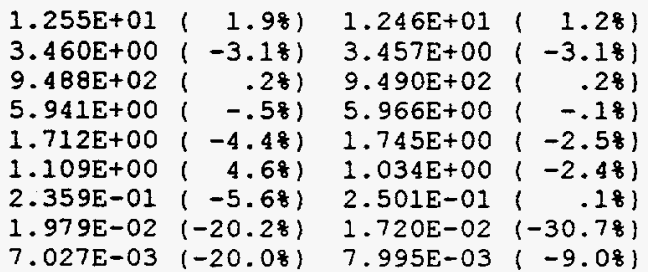

units: curies/gram U

$\begin{array}{rlrrrrr}55 & \operatorname{cs} 134 & 7.823 \mathrm{E}-02 & 6.578 \mathrm{E}-02 & (-15.98) & 6.340 \mathrm{E}-02 & (-19.08) \\ 55 & \operatorname{cs} 137 & 7.451 \mathrm{E}-02 & 7.504 \mathrm{E}-02 & (.78) & 7.503 \mathrm{E}-02 & (.78) \\ 63 & \text { eu154 } & 4.814 \mathrm{E}-03 & 5.757 \mathrm{E}-03 & (19.68) & 3.756 \mathrm{E}-03 & (-22.08)\end{array}$





\section{APPENDIX E}

\section{MEASURED AND COMPUTED ISOTOPIC CONCENTRATIONS FOR TURKEY POINT UNIT 3 FUEL SAMPLES}

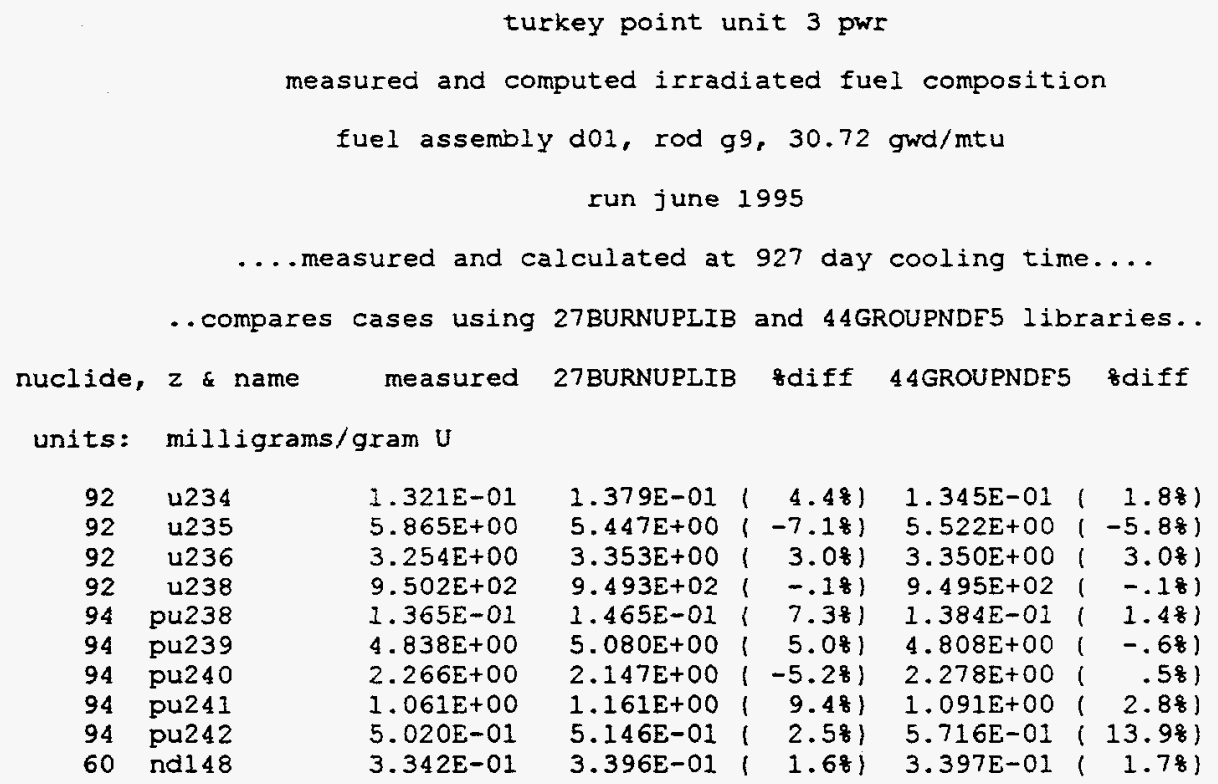

turkey point unit 3 pwr

measured and computed irradiated fuel composition

fuel assembly d01, rod g10, 30.51 gwd/mtu

run june 1995

... measured and calculated at 927 day cooling time...

.. compares cases using 27BURNUPLIB and 44GROUPNDF5 libraries..

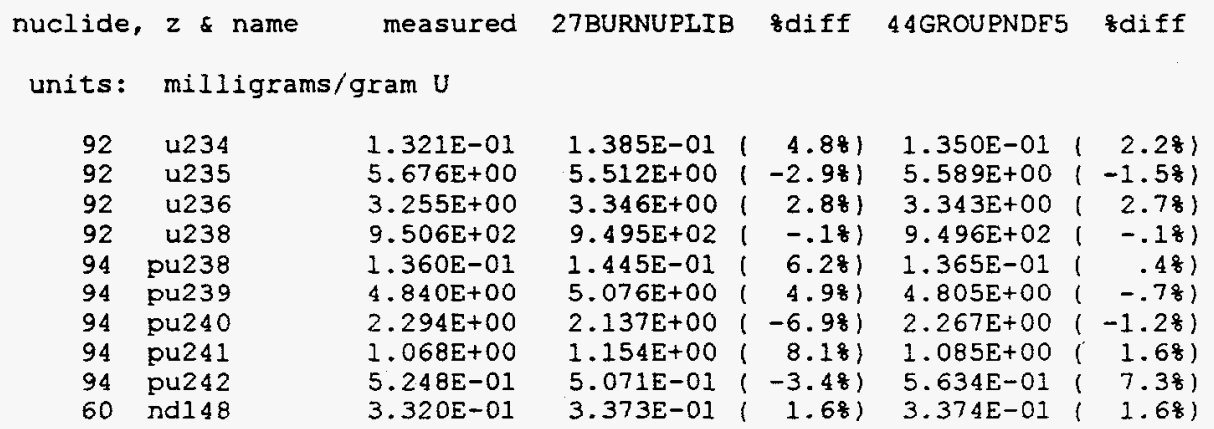


turkey point unit 3 pwr

measured and computed irradiated fuel composition

fuel assembly d01, rod h9, $31.56 \mathrm{gwd} / \mathrm{mtu}$

run june 1995

... measured and calculated at 927 day cooling time...

. compares cases using 27BURNUPLIB and 44GROUPNDE5 libraries..

nuclide, $z$ \& name measured 27BURNUPLIB \&diff 44GROUPNDF5 8diff

units: milligrams/gram U

\begin{tabular}{|c|c|c|c|c|c|c|}
\hline 92 & 4234 & $1.225 \mathrm{E}-01$ & $1.359 \mathrm{E}-01$ & $(10.98)$ & 1. $324 \mathrm{E}-01$ & 8.181 \\
\hline 92 & u235 & $5.584 E+00$ & $5.190 E+00$ & $(-7.18)$ & $5.263 E+00$ & $(-5.78)$ \\
\hline 92 & 4236 & $3.174 \mathrm{E}+00$ & $3.381 E+00$ & 6.581 & $3.379 E+00$ & 6.581 \\
\hline 92 & u238 & $9.495 E+02$ & $9.485 E+02$ & -.181 & $9.487 E+02$ & -.181 \\
\hline 94 & pu238 & $1.426 \mathrm{E}-01$ & $1.547 \mathrm{E}-01$ & 8.581 & $1.462 \mathrm{E}-01$ & 2.681 \\
\hline 94 & pu239 & $4.930 E+00$ & $5.093 E+00$ & 3.381 & $4.819 E+00$ & $(-2.38)$ \\
\hline 94 & pu240 & $2.295 E+00$ & $2.188 \mathrm{E}+00$ & $(-4.78)$ & $2.321 \mathrm{E}+00$ & 1.181 \\
\hline 94 & pu241 & $1.104 E+00$ & $1.186 E+00$ & 7.481 & $1.114 \mathrm{E}+00$ & .981 \\
\hline 94 & pu242 & $5.477 \mathrm{E}-01$ & $5.446 E-01$ & -.681 & $6.049 \mathrm{E}-01$ & $(10.48)$ \\
\hline 60 & ndl 48 & $3.434 E-01$ & $3.488 E-01$ & 1.681 & $3.490 E-01$ & $1.68)$ \\
\hline
\end{tabular}

turkey point unit 3 pwr

measured and computed irradiated fuel composition

fuel assembly d04, rod $\mathrm{g} 9,31.26 \mathrm{gwd} / \mathrm{mtu}$

run june 1995

....measured and calculated at 927 day cooling time...

. compares cases using 27BURNUPLIB and 44GROUPNDF5 libraries..

\begin{tabular}{|c|c|c|c|c|c|c|}
\hline nuclide, & $z \&$ name & measured & 27 BURNUPLIB & odiff & 44 GROUPNDF 5 & zdiff \\
\hline units: & \multicolumn{6}{|c|}{ milligrams/gram U } \\
\hline 92 & ט234 & $1.131 \mathrm{E}-01$ & $1.366 E-01$ & $(20.8 \%)$ & $1.332 \mathrm{E}-01$ & $(17.78)$ \\
\hline 92 & u235 & $5.509 E+00$ & $5.280 E+00$ & $(-4.28)$ & $5.354 \mathrm{E}+00$ & $(-2.88)$ \\
\hline 92 & $\mathrm{u} 236$ & $3.156 \mathrm{E}+00$ & $3.371 E+00$ & 6.881 & $3.369 \mathrm{E}+00$ & 6.781 \\
\hline 92 & $\mathrm{u} 238$ & $9.499 \mathrm{E}+02$ & $9.488 E+02$ & -.181 & $9.490 \mathrm{E}+02$ & $-.18)$ \\
\hline 94 & pu238 & $1.382 E-01$ & $1.518 E-01$ & $9.88)$ & $1.434 E-01$ & $3.88)$ \\
\hline 94 & pu239 & $4.941 E+00$ & $5.088 E+00$ & 3.081 & $4.815 E+00$ & $(-2.68)$ \\
\hline 94 & pu 240 & $2.320 E+00$ & $2.174 \mathrm{E}+00$ & $(-6.38)$ & $2.306 \mathrm{E}+00$ & $(-.68)$ \\
\hline 94 & pu241 & $1.124 \mathrm{E}+00$ & $1.177 \mathrm{E}+00$ & 4.781 & $1.106 \mathrm{E}+00$ & $(-1.68)$ \\
\hline 94 & pu242 & $5.428 \mathrm{E}-01$ & $5.338 E-01$ & $(-1.68)$ & $5.929 \mathrm{E}-01$ & 9.281 \\
\hline 60 & nd 148 & 3. $400 \mathrm{E}-01$ & $3.455 E-01$ & $(1.68)$ & $3.457 \mathrm{E}-01$ & 1.781 \\
\hline
\end{tabular}


turkey point unit 3 pwr

measured and computed irradiated fuel composition

fuel assembly d04, rod glo, $31.31 \mathrm{gwd} / \mathrm{mtu}$

run june 1995

....measured and calculated at 927 day cooling time...

. compares cases using 27BURNUPIIB and 44GROUPNDF5 libraries..

nuclide, z

measured

27BURNUPLIB 염diff

44GROUPNDE5

odiff

units: milligrams/gram $U$

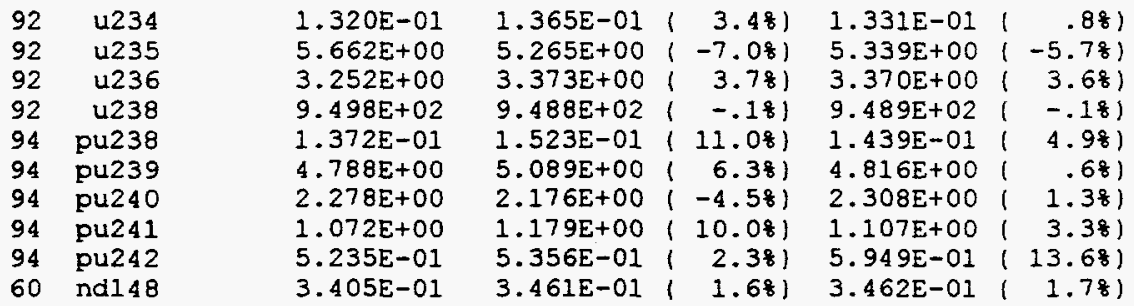





\section{APPENDIX F \\ EFFECT OF INCORRECT ABSORBER SPECIFICATION FOR TRINO VERCELLES CALCULATIONS}

After completion of analyses included in this report, an error was identified in the input for all Trino Vercelles models. Specifically, the composition of the $\mathrm{Ag}-\mathrm{In}-\mathrm{Cd}$ absorber material was defined as $80 \% \mathrm{Ag}, 15 \% \mathrm{In}$, and $15 \% \mathrm{Cd}$, rather than the correct composition of $80 \% \mathrm{Ag}$, $15 \% \mathrm{In}$, and $5 \% \mathrm{Cd}$. Because the absorber material was specified in SCALE input as an arbitrary material, which allows considerable latitude in user input specifications, no error was detected by SCALE. Thus calculations were performed using $150 \%$ of the nominal cadmium content in the absorber material. However, despite the magnitude of this error, it was expected to result in very little effect on the isotopic predictions performed based on the erroneous specification. This appendix discusses briefly why no significant effect is expected and provides the results of supplementary scoping calculations performed to determine the net effect. These scoping calculations confirm that the effect of the error is indeed small. Because of the time and effort that would be required to redo all Trino calculations and revise the contents of the body of this report relative to the inconsequential changes that would result, it was decided to forego a revision and instead simply demonstrate that the effect of the error was negligible.

As discussed in Sect. 2.1 and shown in Table 5, absorber rod insertion was modeled only during the first of three subcycles in the first cycle; the absorber was not present during the last two-thirds of the first subcycle and all of the second subcycle. Thus the effect of the error was diluted by subsequent burnup. In addition, the error introduced by the overspecification of cadmium is likely to be on the order of error introduced by assumptions made in the development of the assembly model. First, absorber rod positions were not known explicitly and were assumed to be uniformly distributed around the core. Second, although the spent fuel samples were obtained primarily from axial locations distant from the partially inserted rod, the 1-D nature of SAS2H necessitated the approximation of a homogenized $30 \%$ absorber $/ 70 \%$ moderator material to represent the effect of a rod that was axially inserted by $30 \%$. Thus models for samples located near the top of the core, and therefore near the absorber rod, would 
see less absorber than was present in reality, while samples located further from the top of the core would see more absorber effects than were actually present.

Table F.1 lists the results of a revised calculation performed for a single fuel sample with the corrected cadmium fraction in the input. These can be compared with the results listed for the same pin using the erroneous cadmium fraction, as given in Appendix D. Table F.2 provides a side-by-side comparison of the results of the reported (body of report and Appendix D) and corrected (Table F.1) results for this fuel sample. Note that the corrected results are all within $1 \%$ of the earlier results, and that for the most part the largest effect is seen for nuclides for which there is already a large uncertainty/bias between measured and computed isotopic concentrations (e.g., ${ }^{242} \mathrm{Am}$ or ${ }^{244} \mathrm{Cm}$ ). 
Table F.1 Results of corrected depletion calculations for Assembly 509-069, Rod E1 1, Level 2

\begin{tabular}{|c|c|c|c|c|c|}
\hline \multicolumn{6}{|c|}{$\begin{array}{l}\text { trino vercelles pwr } \\
\text { measured and computed irradiated fuel composition }\end{array}$} \\
\hline \multicolumn{6}{|c|}{ run June 1996} \\
\hline & . compares & s cases us & ng 27BURNUPLIB and & 44GROUPNDF5 & Libraries.. \\
\hline nuclide, & $z$ \& name & measured & 27BURNUPLIB $\quad$ gdiff & 44GROUPNDF5 & sdiff \\
\hline \multicolumn{6}{|c|}{ milligrams/gram u } \\
\hline 92 & $\mathrm{u} 235$ & $1.436 \mathrm{E}+01$ & $1.457 \mathrm{E}+01(1.48)$ & $1.465 \mathrm{E}+01$ & $(2.08)$ \\
\hline 92 & $\mathrm{u} 236$ & $3.317 E+00$ & $3.152 \mathrm{E}+00(-5.08)$ & $3.144 \mathrm{E}+00$ & $(-5.28)$ \\
\hline 92 & 4238 & $9.518 E+02$ & $9.517 E+02(0.08)$ & $9.519 \mathrm{E}+02$ & $(0.08)$ \\
\hline 94 & pu239 & $5.755 E+00$ & $5.787 E+00(0.58)$ & $5.523 \mathrm{E}+00$ & $(-4.08)$ \\
\hline 94 & pu2 40 & $1.520 \mathrm{E}+00$ & $1.458 \mathrm{E}+00(-4.18)$ & $1.547 \mathrm{E}+00$ & $(1.88)$ \\
\hline 94 & pu241 & $8.850 E-01$ & $9.080 \mathrm{E}-01(2.68)$ & $8.656 \mathrm{E}-01$ & $(-2.28)$ \\
\hline 94 & pu242 & $1.720 \mathrm{E}-01$ & $1.568 E-01(-8.88)$ & $1.778 \mathrm{E}-01$ & $(3.48)$ \\
\hline 60 & nd 148 & $2.307 \mathrm{E}-01$ & $2.272 E-01(-1.58)$ & $2.273 E-01$ & $(-1.58)$ \\
\hline 95 & $\operatorname{am} 242$ & $1.388 E-03$ & $2.197 \mathrm{E}-03(58.38)$ & $1.633 \mathrm{E}-03$ & $(17.68)$ \\
\hline 95 & $\operatorname{am} 243$ & $2.394 \mathrm{E}-02$ & $2.274 \mathrm{E}-02(-5.08)$ & $2.546 \mathrm{E}-02$ & $(6.38)$ \\
\hline 96 & $\mathrm{~cm} 242$ & $1.769 \mathrm{E}-02$ & $1.378 \mathrm{E}-02(-22.18)$ & $1.262 \mathrm{E}-02$ & $(-28.68)$ \\
\hline 96 & $\mathrm{~cm} 244$ & $4.675 \mathrm{E}-03$ & $3.357 E-03 \quad(-28.28)$ & $4.179 E-03$ & $(-10.68)$ \\
\hline units: & curies/gram & u & & & \\
\hline 55 & $\operatorname{cs} 134$ & $6.059 \mathrm{E}-02$ & $4.847 E-02 \quad(-20.08)$ & $4.660 \mathrm{E}-02$ & $(-23.18)$ \\
\hline 55 & $\operatorname{cs} 137$ & $6.337 \mathrm{E}-02$ & $6.359 E-02(0.38)$ & $6.358 \mathrm{E}-02$ & $(0.38)$ \\
\hline 63 & eu154 & $3.664 E-03$ & $4.140 \mathrm{E}-03(13.08)$ & $2.701 \mathrm{E}-03$ & $(-26.38)$ \\
\hline
\end{tabular}


Table F.2 Differences between reported and corrected calculated isotopic concentrations

\begin{tabular}{|c|c|c|c|c|c|c|}
\hline \multirow[t]{2}{*}{ nuclide } & $\begin{array}{c}\text { Reported } \\
\text { (27BURNUPIIB) }\end{array}$ & $\begin{array}{c}\text { Corrected } \\
\text { (27BURNUPLIB) }\end{array}$ & \multirow[t]{2}{*}{$g$ diff } & \multirow[t]{2}{*}{$\begin{array}{c}\text { Reported } \\
\text { (44GROUPNDF5) }\end{array}$} & \multirow[t]{2}{*}{$\begin{array}{c}\text { Corrected } \\
(44 \text { GROUPNDF5) }\end{array}$} & \multirow[t]{2}{*}{$8 \operatorname{diff}$} \\
\hline & milligl & tams/gram u & & & & \\
\hline u235 & $1.463 E+01$ & $1.457 \mathrm{E}+01$ & 0.418 & $1.472 \mathrm{E}+01$ & $1.465 \mathrm{E}+01$ & 0.488 \\
\hline u236 & $3.152 \mathrm{E}+00$ & $3.152 \mathrm{E}+00$ & $0.00 \%$ & $3.143 \mathrm{E}+00$ & $3.144 \mathrm{E}+00$ & -0.038 \\
\hline 4238 & $9.516 \mathrm{E}+02$ & $9.517 \mathrm{E}+02$ & -0.018 & $9.518 \mathrm{E}+02$ & $9.519 \mathrm{E}+02$ & -0.018 \\
\hline pu239 & $5.808 \mathrm{E}+00$ & $5.787 E+00$ & 0.368 & $5.546 \mathrm{E}+00$ & $5.523 E+00$ & 0.418 \\
\hline pu240 & $1.466 \mathrm{E}+00$ & $1.458 \mathrm{E}+00$ & 0.558 & $1.555 \mathrm{E}+00$ & $1.547 \mathrm{E}+00$ & 0.518 \\
\hline pu241 & $9.131 E-01$ & $9.080 \mathrm{E}-01$ & 0.568 & $8.707 \mathrm{E}-01$ & $8.656 E-01$ & 0.598 \\
\hline pu242 & $1.578 \mathrm{E}-01$ & $1.568 \mathrm{E}-01$ & 0.638 & $1.790 \mathrm{E}-01$ & $1.778 \mathrm{E}-01$ & 0.678 \\
\hline nd148 & $2.271 E-01$ & $2.272 \mathrm{E}-01$ & $-0.04 \frac{8}{8}$ & $2.272 E-01$ & $2.273 E-01$ & -0.048 \\
\hline $\operatorname{am} 242$ & $2.226 \mathrm{E}-03$ & $2.197 \mathrm{E}-03$ & $1.30 \%$ & $1.656 \mathrm{E}-03$ & $1.633 E-03$ & 1.398 \\
\hline $\operatorname{am} 243$ & $2.293 E-02$ & $2.274 \mathrm{E}-02$ & $0.83 \%$ & $2.568 \mathrm{E}-02$ & $2.546 E-02$ & 0.868 \\
\hline $\operatorname{cm} 242$ & $1.391 \mathrm{E}-02$ & $1.378 \mathrm{E}-02$ & 0.938 & $1.274 E-02$ & $1.262 E-02$ & 0.948 \\
\hline $\operatorname{cm} 244$ & $3.391 E-03$ & $3.357 \mathrm{E}-03$ & 1.008 & $4.224 \mathrm{E}-03$ & $4.179 E-03$ & 1.078 \\
\hline
\end{tabular}

units: curies/gram u

$\begin{array}{rrrrrrr}\operatorname{cs} 134 & 4.837 E-02 & 4.847 E-02 & -0.218 & 4.651 E-02 & 4.660 E-02 & -0.198 \\ \operatorname{cs} 137 & 6.356 E-02 & 6.359 E-02 & -0.058 & 6.356 E-02 & 6.358 E-02 & -0.038 \\ \text { eu154 } & 4.141 E-03 & 4.140 E-03 & 0.028 & 2.704 E-03 & 2.701 E-03 & 0.118\end{array}$


ORNL/TM-13317

\section{INTERNAL DISTRIBUTION}

1. C. W. Alexander

2. S. M. Bowman

3. B. L. Broadhead

4. J. A. Bucholz

5. R. D. Dabbs

6-10. M. D. DeHart

7. M. B. Emmett

8-12. O. W. Hermann

13. M. Kuliasha

14. L. C. Leal

15. J. J. Lichtenwalter

16. S. B. Ludwig

17. S. K. Martin

18. G. E. Michaels

19. B. D. Murphy

20-24. L. F. Norris

25. J. V. Pace
26-30. C. V. Parks

31. L. M. Petrie

32. R. T. Primm

33. J.-P. Renier

34. J. W. Roddy

35. R. W. Roussin

36. J. C. Ryman

37. C. H. Shappert

38. C. O. Slater

39. R. M. Westfall

40. B. A. Worley

41. R. Q. Wright

42-43. Laboratory Records Dept.

44. Laboratory Records,

45. Document Reference Sect

46. ORNLY-12 Research Library

47. Central Research Library

48. ORNL Patent Section

\section{EXTERNAL DISTRIBUTION}

49. R. Anderson, General Nuclear Systems, Inc., 220 Stoneridge Dr., Columbia, SC 29210

50. M. G. Bailey, Office of Nuclear Material Safety \& Safeguards, U.S. Nuclear Regulatory Commission, MS OWFN 6 G22, Washington, DC 20555

51. L. Barrett, Office of Civilian Radioactive Waste Management, RW-232 20545, U.S. Department of Energy, Washington, DC 20545

52. P. Baylor, Office of Civilian Radioactive Waste Management, RW-36, U.S. Department of Energy, Washington, DC 20545

53. C. J. Benson, Bettis Atomic Power Laboratory, P.O. Box 79, West Mifflin, PA 15122

54. J. Bickel, U.S. Department of Energy, Albuquerque Operations Office, P.O. Box 5400, Albuquerque, NM 87115

55. J. Boshoven, GA Technologies, Inc., P.O. Box 85608, 10955 John J. Hopkins Dr., San Diego, CA 92121

56. M. C. Brady, Sandia National Laboratories, 1261 Town Center Drive, Room 421A, Las Vegas, NV 89134

57. P. Bunton, U.S. Department of Energy, RW-1, Washington, DC 20545

58. R. J. Cacciapouti, Yankee Atomic Electric Co., 1617 Worcester Rd., Framington, MA 01701

59. D. E. Carlson, U.S. Nuclear Regulatory Commission, Spent Fuel Project Office, OWFN $6 \mathrm{G} 22$, Washington, DC 20555

60. R. D. Carlson, Argonne National Laboratory, 9700 S. Cass Ave., Bldg.308, Argonne, IL $60439-4825$

61. C. R. Chappell, U.S. Nuclear Regulatory Commission, Office of Nuclear Material Safety and Safeguards, TWFN 8F5, Washington, DC 20555 
62. J. S. Choi, Lawrence Livermore National Laboratory, P.O. Box 808, Livermore, CA 94550

63. J. Clark, 2650 Park Tower Drive, Suite 800 , Vienna, VA 22180

64. J. Conde, Consejo de Seguridad Nuclear, Justo Dorado, 11, 28040 Madrid, Spain

65. D. R. Conners, Bettis Atomic Power Laboratory, P.O. Box 79, West Mifflin, PA 15122

66. M. Conroy, U.S. Department of Energy, M-261 Quince Orchard, Washington, DC 20585-0002

67. W. Davis, Cogema, 101 Convention Center Drive, Suite 527, MS 423, Las Vegas, NV 89109

68. D. Dawson, Transnuclear, Inc., 2 Skyline Dr., Hawthorne, NY 10532-2120

69. T. W. Doering, Cogema, MS 423, Suite 527, P.O. Box 98608, 101 Convention Center Drive, Las Vegas, NV 89109

70. R. Doman, Nuclear Packaging, Inc., 1010 S. 336th St., Suite 220, Federal Way, WA 98003

71. E. P. Easton, U.S. Nuclear Regulatory Commission, Office of Nuclear Materials Safety and Safeguards, OWFN 6 F18, Washington, DC 20555

72. R. C. Ewing, Sandia National Laboratories, P.O. Box 5800, Div. 6643, MS 0716, Albuquerque, NM 87185-0716

73. I. Gauld, Whiteshell Laboratories, AECL Research, Pinawa Manitoba ROElLO Canada

74. G. Gualdrini, ENEA-TIB/FICS, C.R.E. "E. Clementel," Via Mazzini, 2, I-40139 Bologna, Italy

75. H. Geiser, Wissenschaftich-Technische Ingenieurberatung GmbH, P.O. Box 13 40, 52410 Julich, Federal Republic of Germany

76-78. D. E. Hampton, Sandia National Laboratories, P.O. Box 5800, Div. 6302, MS 1333, Albuquerque, NM 87185-0716

79. S. Hanauer, U.S. Department of Energy, RW-22, Washington, DC 20545

80. K. J. Hardin, U.S. Nuclear Regulatory Commission, TWFN 10 C9, Washington, DC 20555

81. C. J. Haughney, U.S. Nuclear Regulatory Commission, Spent Fuel Project Office, OWFN 6 F18, Washington, DC 20555

82. L. Hassler, Babcock \& Wilcox, P.O. Box 10935, Lynchburg, VA 24506-0935

83. C. A. Hrabel, U.S. Nuclear Regulatory Commission, TWFN 10 C9, Washington, DC 20555

84. U. Jenquin, Battelle Pacific Northwest Laboratory, P.O. Box 999, Richland, WA 99352

85. E. Johnson, E. R. Johnson Associates, Inc., 9302 Lee Hwy, Suite 200, Fairfax, VA 22031

86. G. Kirchner, University of Bremen, FB 1 Postfach 330440, D-W-2800 Bremen 33, Federal Republic of Germany

87. C. Kouts, Office of Civilian Radioactive Waste Management, RW-36, U.S. Department of Energy, Washington, DC 20545

88. S. Kraft, Nuclear Energy Institute, 1776 I Street, Suite 400, Washington, DC 20086

89. P. Krishna, TRW Environmental Safety Systems, 600 Maryland Ave. S.W., Suite 695, Washington, DC 20024

90. A. Kubo, 2650 Park Tower Drive, Suite 800, Vienna, VA 22180

91. W. H. Lake, Office of Civilian Radioactive Waste Management, U.S. Department of Energy, RW-46, Washington, DC 20585

92. R. Lambert, Electric Power Research Institute, 3412 Hillview Ave., Palo Alto, CA 94304

93-97. D. Lancaster, 2650 Park Tower Drive, Suite 800, Vienna, VA 22180

98. D. Langstaff, U.S. Department of Energy, Richland Operations Office, P.O. Box 550, Richland, WA 99352 
99. C. Marotta, 1504 Columbia Ave., Rockville, MD 20850

100. M. Mason, Transnuclear, Two Skyline Drive, Hawthorne, NY 10532-2120

101. J. Massey, Sierra Nuclear Corporation, 5619 Scotts Valley Drive, Number 240, Scotts Valley, CA 95066

102. W. Mings, U.S. Department of Energy, Idaho Operations Office, 550 2nd St., Idaho Falls, ID 83401

103. A Mobashevan, Roy F. Weston, Inc., 955 L'Enfant Plaza, SW, 8th Floor, Washington, DC 20024

104. M. Mount, Lawrence Livermore National Laboratory, P.O. Box 808, Livermore, CA 94550

105. P. K. Nair, Manager, Engineered Barrier System, Center for Nuclear Waste Regulatory Analyses, Southwest Research Institute, 6220 Culebra Road, San Antonio, TX 782385166

106. D. Napolitano, Nuclear Assurance Corp., 5720 Peachtree Parkway, Norcross, GA 30092

107. C. W. Nilsen, Office of Nuclear Material Safety and Safeguards, U.S. Nuclear Regulatory Commission, MS TWFN-9F29, Washington, DC 20555

108-109. Office of Scientific and Technical Information, U.S. Department of Energy, P.O. Box 62, Oak Ridge, TN 37831

110. Office of the Assistant Manager for Energy Research and Development, Department of Energy Oak Ridge Operations (DOE-ORO), P.O. Box 2008, Oak Ridge, TN 37831

111. N. L. Osgood, U.S. Nuclear Regulatory Commission, Office of Nuclear Materials Safety and Safeguards, OWFN 6 G22, Washington, DC 20555

112. O. Ozer, Electric Power Research Institute, 3412 Hillview Ave., Palo Alto, CA 94304

113. P. Pacquin, General Nuclear Systems, Inc., 220 Stoneridge Dr., Columbia, SC 29210

114. T. Parish, Department of Nuclear Engineering, Texas A \& M University, College Station, TX 77843-3313

115. F. Prohammer, Argonne National Laboratory, 9700 S. Cass Ave., Bldg.308, Argonne, II $60439-4825$

116-118. M. Rahimi, 2650 Park Tower Drive, Suite 800, Vienna, VA 22180

119. B. Reid, Battelle Pacific Northwest Laboratory, P.O. Box 999, Richland, WA 99352

120. C. Rombough, CTR Technical Services, Inc., 5619 Misty Crest Dr., Arlington, TX $76017-4147$

121. T. L. Sanders, Sandia National Laboratories, P.O. Box 5800, Div. 6609, MS 0720, Albuquerque, NM 87185-0716

122. M. Schaeffer, Brookhaven National Laboratory, Plant Engineering, Building 134C, P.O. Box 5000, Upton, NY 11973-5000

123. M. Smith, U.S. Department of Energy, Yucca Mountain Project Office, 101 Convention Center Dr., Las Vegas, NV 89190

124. M. Smith, Virginia Power Co., P.O. Box 2666, Richmond, VA 23261

125. K. B. Sorenson, Sandia National Laboratories, P.O. Box 5800, Div. 6643, MS 0716, Albuquerque, NM 87185-0716

126. J. B. Stringer, Duke Engineering \& Services, 230 S. Tryon St., P.O. Box 1004, Charlotte, NC 28201-1004

127. F. C. Sturz, Office of Nuclear Material Safety \& Safeguards, U.S. Nuclear Regulatory Commission, MS OWFN 6 G22, Washington, DC 20555

128. J. Sun, Florida Power \& Light Co., P.O. Box 029100, Miami, FL 33102

129. T. Suto, Power Reactor and Nuclear Fuel Development Corp., 1-9-13, Akasaka, Minato$\mathrm{Ku}$, Tokyo, Japan

130. R. J. Talbert, Battelle Pacific Northwest Laboratory, P.O. Box 999, Richland, WA 99352

131. H. Taniuchi, Kobe Steel, Ltd., 2-3-1 Shinhama, Arai-Cho, Takasago, 676 Japan

132. T. Taylor, INEL, P.O. Box 4000, MS 3428, Idaho Falls, ID 83403 
133. B. Thomas, VECTRA Technologies, Inc., 6203 San Ignacio Ave., Suite 100, San Jose, CA 95119

134. D. A. Thomas, Cogema, 101 Convention Center Drive, Suite 527, MS 423, Las Vegas, NV 89109

135. J. R. Thornton, TRW Enviornmental Safety Systems, 2650 Park Tower Dr., Suite 800, Vienna, VA 22180

136. J. Vujic, Department of Nuclear Engineering, University of California at Berkeley, Berkeley, CA 94720

137. G. Walden, Duke Power Co., P.O. Box 33189, Charlotte, NC 28242

138. M. E. Wangler, U.S. Department of Energy, EH-33.2, Washington, DC 20585-0002

139. R. M. Weller, U.S. Nuclear Regulatory Commission, TWFN 7 C6, Washington, DC 20555

140. A. Wells, 2846 Peachtree Walk, Duluth, GA 30136

141. W. Weyer, Wissenschaftlich-Technische Ingenieurberatung GMBH, Mozartstrasse 13, 5177 Titz-Rodingen, Federal Republic of Germany

142. B. H. White, U.S. Nuclear Regulatory Commission, Spent Fuel Project Office, OWFN 6 F18, Washington, DC 20555

143. J. Williams, Office of Civilian Radioactive Waste Management, U.S. Department of Energy, RW-46, Washington, DC 20545

144. M. L. Williams, LSU Nuclear Science Center, Baton Rouge, LA 70803

145. C. J. Withee, U.S. Nuclear Regulatory Commission, Spent Fuel Project Office, OWFN 6 G22, Washington, DC 20555

146. R. Yang, Electric Power Research Institute, 3412 Hillview Ave., Palo Alto, CA 94304 